Facilities Management

\title{
Facility Effluent Monitoring Plan for the 327 Facility
}

In case of termination or transfer, return this manual to Document Control K3-70

\section{RECEIVED}

NOV 051997

$08 \mathrm{TI}$

Responsible Staff Member:

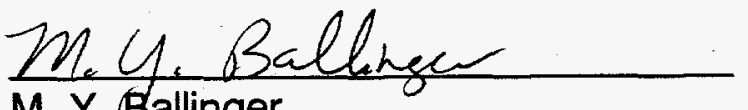

M. Y. Ballinger

Effluent Monitoring

Approved for Use and Application by:

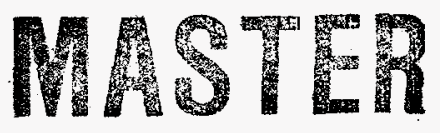

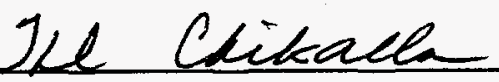

T. D. Chikalla, Director Facilities and Operations

Battelle

Pacific Northwest Laboratories

Richland, Washington 99352
DIBTARUTION OF THIS DOCUMENT IS UHAMTIE

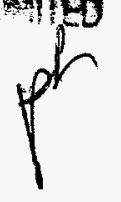




\title{
DISCLAIMER
}

This report was prepared as an account of work sponsored by an agency of the United States Government. Neither the United States Government nor any agency thereof, nor Battelle Memorial Institute, nor any of their employees, makes any warranty, expressed or implied, or assumes any legal liability or responsibility for the accuracy, completeness, or usefulness of any information, apparatus, product, or process disclosed, or represents that its use would not infringe privately owned rights. Reference herein to any specific commercial product, process, or service by trade name, trademark, manufacturer, or otherwise does not necessarily constitute or imply its endorsement, recommendation, or favoring by the United States Government or any agency thereof, or Battelle Memorial Institute. The views and opinions of authors expressed herein do not necessarily state or reflect those of the United States Government or any agency thereof.

\author{
PACIFIC NORTHWEST LABORATORY \\ operated by \\ BATTELLE MEMORIAL INSTITUTE \\ for the \\ UNITED STATES DEPARTMENT OF ENERGY \\ under Contract DE-AC06-76RLO 1830
}




\section{DISCLAIMER}

Portions of this document may be illegible electronic image products. Images are produced from the best available original document. 


\section{Summary}

The 327 Facility provides office and laboratory space for Pacific Northwest Laboratory (PNL) scientific and engineering staff conducting multidisciplinary research in the areas of postirradiated fuels and structural materials. The facility is designed to accommodate the use of radioactive and hazardous materials in the conduct of these activities. The following summarizes the airborne emissions and liquid effluents and the results of the Facility Effluent Monitoring Plan (FEMP) determination for the facility. The complete monitoring plan includes characterization of effluent streams, monitoring/sampling design criteria, a description of the monitoring systems and sample analysis, and quality assurance requirements.

\section{Airborne Emissions}

\section{Liquid Effluents}

\section{FEMP Determination}

Potential radioactive airborne emissions in the 327 Facility have been characterized and all airborne release pathways have been verified. Stack monitors (samplers) were upgraded to meet 40 CFR 61 criteria. Two stacks at the 327 Facility (EP-327-01-S and EP-327-02V) are currently registered with the Washington Department of Health as required by WAC 246-247. Nonradioactive airborne emissions have not been characterized, but characterization efforts are planned and will proceed in the course of compliance with state air toxics regulations and as the Clean Air Act Amendments are fully implemented.

The 327 Facility discharges to four sewer systems (radioactive liquid waste system (RLWS), retention process sewer (RPS), process and sanitary sewers (PS and SNS)). Liquid effluent releases in the 327 Facility are either administratively or physically controlled. Most connections to the process sewer that have the potential to release regulated effluent have been plugged. Unplugged connections include floor and sump drains that have been modified with stand pipes to prevent uncontrolled discharge, and other (primarily laboratory sink and hood) drains that have been posted with labels identifying the type of drain and liquid effluent disposal instructions. Selective floor drains in facility service tunnels that must remain open in case of main service line leaks or ruptures are also posted to control disposal of liquid effluents. Verification of the RLWS, RPS, and PS liquid effluent lines is nearing completion and will be completed in 1995.

Liquid effluent lines from the facility enter into the 300 Area liquid effluent system, operated by Westinghouse Hanford Company (WHC). The RPS, PS, and SNS are monitored by WHC at the end of pipe before release to the environment. The RLWS effluent is not released to the environment, but is transferred to the 340 Facility, operated by WHC, and then to the tank farms in the 200 Area. A program to sample liquid effluents from the 327 Facility is underway. Liquid effluent monitoring equipment is being installed and includes a flow proportional liquid sampler, online $\mathrm{pH}$ meter, and conductivity meter. Sampling of the liquid effluents will commence when the samplers are installed. Installation should be complete by the end of 1994 .

An inventory-based method was used to estimate the maximum potential offsite dose if airborne releases from the facility were unmitigated. The projected potential unmitigated dose met criteria ( $>0.1 \mathrm{mrem}$ ) for preparing a FEMP. A list of chemicals in the facility was also obtained and chemicals in greater than reportable quantity were identified to focus on the potential for emissions of nonradioactive hazardous materials. A method to determine the potential emissions of nonradioactive hazardous materials is under development. 



\section{Glossary}

\begin{tabular}{|c|c|}
\hline $\mathrm{AABC}$ & Associated Air Balance Council \\
\hline $\mathrm{ACV}$ & administrative control values \\
\hline $\mathrm{AED}$ & aerodynamic equivalent diameter \\
\hline AKART & all known, available, and reasonable technology \\
\hline AMAD & activity median aerodynamic diameters \\
\hline ANSI & American National Standards Institute \\
\hline ASILs & Acceptable Source Impact Levels \\
\hline BACT & best available control technology \\
\hline CAA & Clean Air Act \\
\hline CAM & continuous air monitor \\
\hline CERCLA & Comprehensive Environmental Response, Compensation, and Liability Act \\
\hline CFR & Code of Federal Regulations \\
\hline DCGs & derived concentration guides \\
\hline DOE & U.S. Department of Energy \\
\hline $\mathrm{DOH}$ & Washington Department of Health \\
\hline $\mathrm{EC}$ & Environmental Compliance Section of PNL \\
\hline EPA & U.S. Environmental Protection Agency \\
\hline ESP & exhaust sample point \\
\hline FEMP & Facility Effluent Monitoring Plan \\
\hline FFTF & Fast Flux Test Facility \\
\hline FWPCA & Federal Water Pollution Control Act \\
\hline HEPA & high-efficiency particulate air \\
\hline HVAC & heating, ventilation, and air conditioning \\
\hline ITAS & International Technology Analytical Services \\
\hline MASR & Missing Air Sample Report \\
\hline MDA & minimum detectable activity \\
\hline MDL & minimum detection levels \\
\hline MFP & mixed fission product \\
\hline MOTA & Materials Open Test Assembly \\
\hline MPCs & maximum permissible concentrations \\
\hline MPD & maximum permissible dose \\
\hline NAAQS & national ambient air quality standards \\
\hline NESHAPS & National Emission Standards for Hazardous Air Pollutants \\
\hline NPDES & national pollutant discharge elimination system \\
\hline OED & offsite emission dose \\
\hline ONE & off-normal event \\
\hline ONO & off-normal occurrence \\
\hline OSR & operational safety requirement \\
\hline $\begin{array}{l}\text { PASR } \\
\text { PCM }\end{array}$ & $\begin{array}{l}\text { Positive Air Sample Report } \\
\text { personnel contamination monitor }\end{array}$ \\
\hline & personnel contamination monitor \\
\hline
\end{tabular}


PM-10

PNL

PS

QC

RAM

RCRA

RLWS

RQ

RPS

RPT

SAR

SNM

SNS

SOP

TAPs

UO

WAC

WCAA

WDOE

WHC

WM particulate matter with diameter greater then 10 microns Pacific Northwest Laboratory

process sewer

quality control

radiation area monitor

Resource Conservation and Recovery Act radioactive liquid waste system reportable quantity retention process sewer radiation protection technician

Safety Analysis Report special nuclear material sanitary sewer safe (or standard) operating procedure

toxic air pollutants

unusual occurrence

Washington Administrative Code

Washington State Clean Air Act

Washington State Department of Ecology

Westinghouse Hanford Company

Waste Management 


\section{Contents}

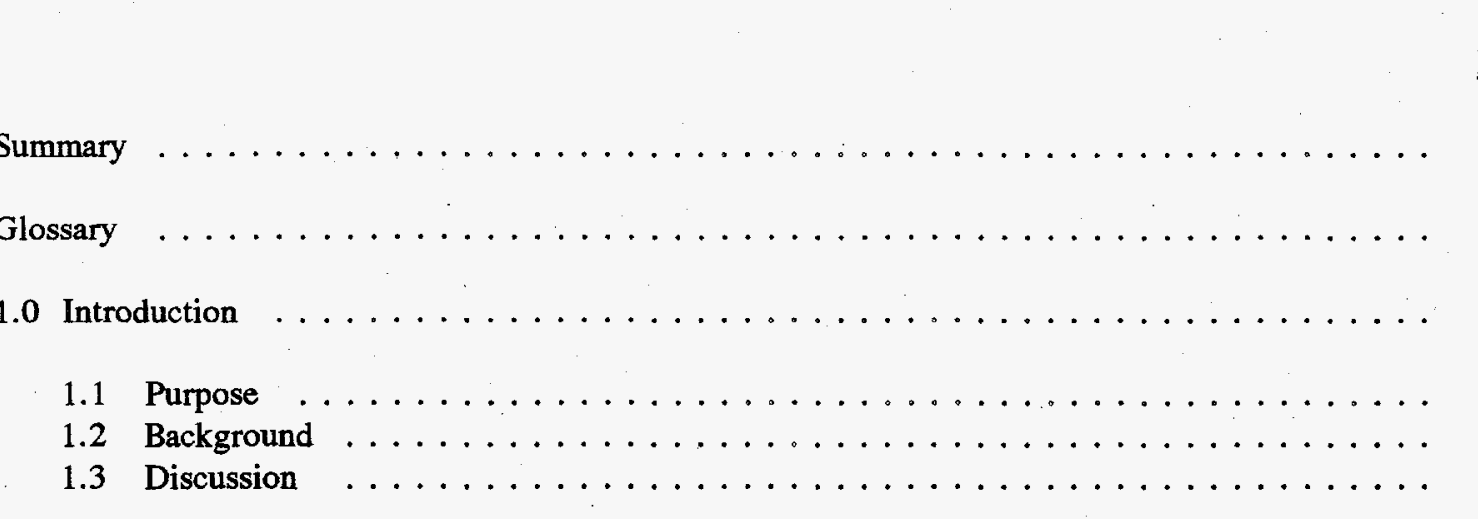

Page No.

Issue

$\underline{\text { Date }}$

2.0 Facility Mission and Description $\ldots \ldots \ldots \ldots \ldots \ldots$

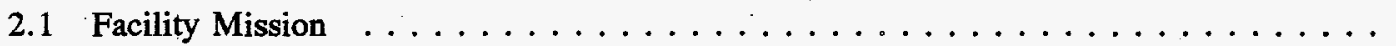

2.2 Geographical Location and Physical Description $\ldots \ldots \ldots \ldots$

2.3 Brief Process Description $\ldots \ldots \ldots \ldots \ldots \ldots \ldots \ldots \ldots \ldots \ldots \ldots$

2.4 Source Term Definition and Description $\ldots \ldots \ldots \ldots \ldots \ldots \ldots$

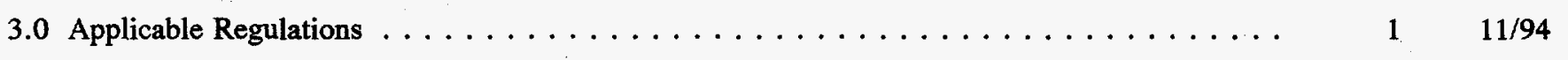

3.1 Introduction $\ldots \ldots \ldots \ldots \ldots \ldots \ldots \ldots \ldots \ldots \ldots \ldots \ldots \ldots \ldots$

3.2 Environmental Regulations $\ldots \ldots \ldots \ldots \ldots \ldots \ldots \ldots \ldots \ldots \ldots \ldots$

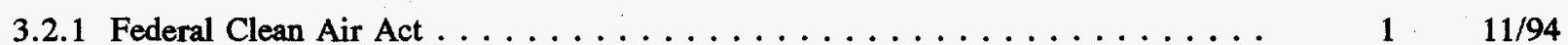

3.2 .2 NESHAPs $\ldots \ldots \ldots \ldots \ldots \ldots \ldots \ldots \ldots \ldots \ldots \ldots \ldots \ldots \ldots \ldots \ldots$

3.2.3 The Washington State Clean Air Act . . . . . . . . . . . . . . . . . . . . . . . . . . . . . . . . . . . $11 / 94$

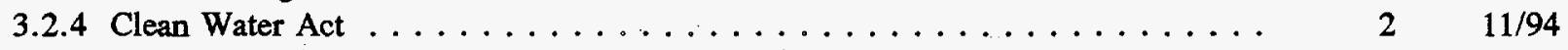

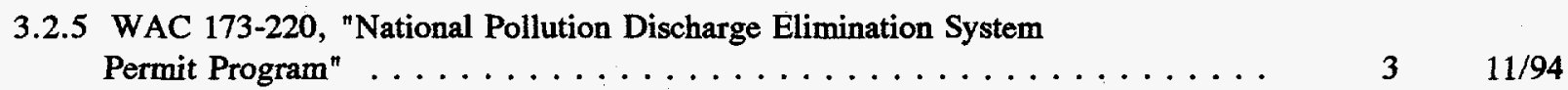

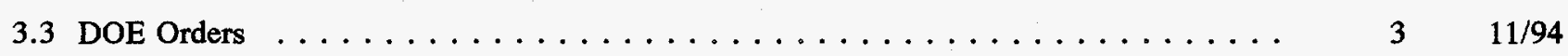

3.3.1 DOE 5400.1, "General Environmental Protection Program" . . . . . . . . . . . $\quad 3 \quad 11 / 94$

3.3.2 DOE 5400.5, "Radiation Protection of the Public and the Environment" . . . . . 4

3.3.3 DOE EH-0173T, Environmental Regulatory Guide for Radiological Monitoring and Environmental Surveillance . . . . . . . . . . . . . . . . . $4 \quad 11 / 94$

3.4 PNL-MA-8, Waste Management and Environmental Compliance . . . . . . . . . . . $4 \quad 11 / 94$

4.0 Effluent Stream Characterization $\ldots \ldots \ldots \ldots \ldots \ldots$

4.1 Identification of Effluent Pathways $\ldots \ldots \ldots \ldots \ldots \ldots \ldots \ldots$

4.1.1 Gaseous and Aerosol Effluent Pathways . . . . . . . . . . . . . . . . . . . . . . . . . . . . . . . . $111 / 94$

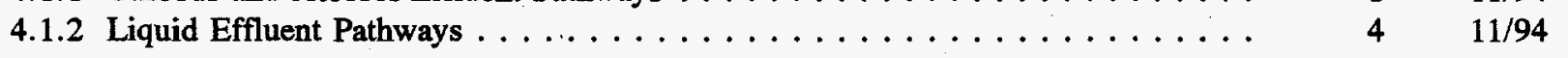

4.2 Facility Inventories $\ldots \ldots \ldots \ldots \ldots \ldots \ldots \ldots \ldots \ldots \ldots \ldots$

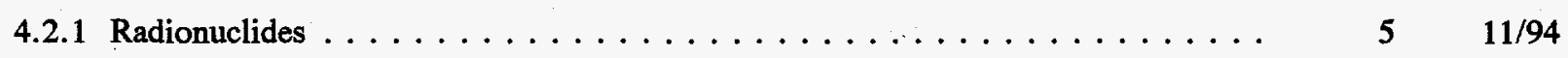


4.3 Characterization of Source Terms Contributing to Effluent $\ldots \ldots \ldots \ldots \ldots \ldots$

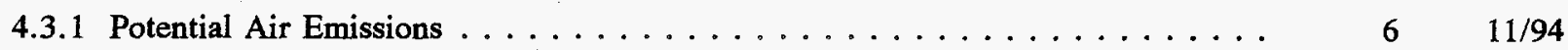

4.3.2 Liquid Source Terms $\ldots \ldots \ldots \ldots \ldots \ldots \ldots \ldots \ldots \ldots \ldots \ldots \ldots \ldots$ 11/94

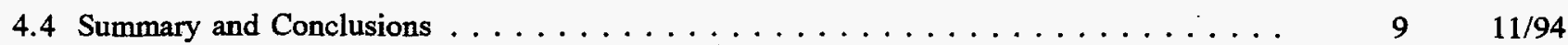

4.5 References . . . . . . . . . . . . . . . . . . . . $11 / 94$

5.0 Effluent Point-of-Discharge Description $\ldots \ldots \ldots \ldots \ldots \ldots \ldots \ldots \ldots \ldots \ldots \ldots$ 11/94

5.1 Airborne Emission Exhaust Points $\ldots \ldots \ldots \ldots \ldots \ldots \ldots \ldots \ldots \ldots \ldots$ 11/94

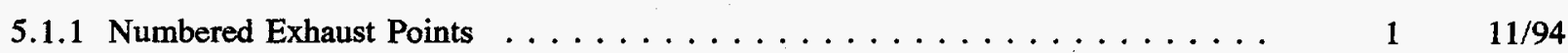

5.1 .2 Other Potential Exhaust Points $\ldots \ldots \ldots \ldots \ldots \ldots \ldots \ldots \ldots \ldots \ldots \ldots \ldots$ 11/94

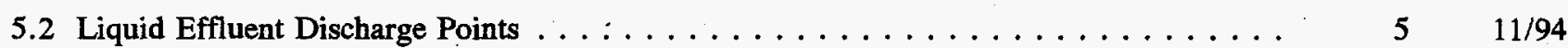

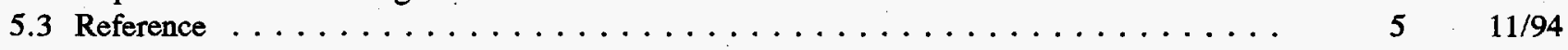

6.0 Effluent Monitoring/Sampling System Design Criteria $\ldots \ldots \ldots \ldots \ldots \ldots \ldots \ldots \ldots \ldots \ldots$ 11/94

6.1 Basis for Design Criteria $\ldots \ldots \ldots \ldots \ldots \ldots \ldots \ldots \ldots \ldots \ldots \ldots \ldots \ldots \ldots \ldots \ldots \ldots 11 / 94$

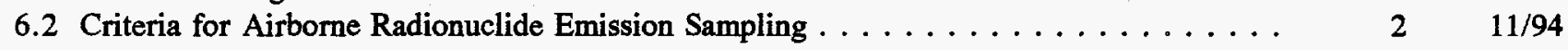

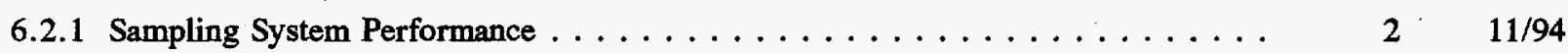

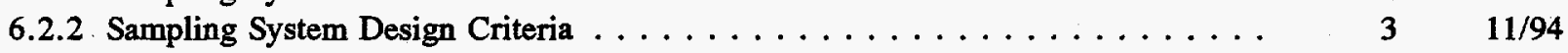

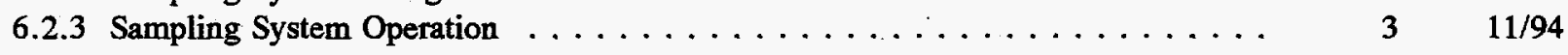

6.3 Criteria for Emission Monitoring $\ldots \ldots \ldots \ldots \ldots \ldots \ldots \ldots \ldots \ldots \ldots \ldots \ldots \ldots$ $5 \ldots \ldots$

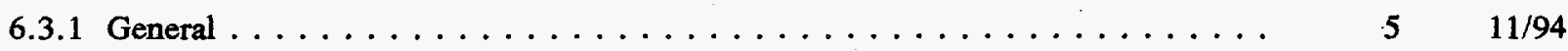

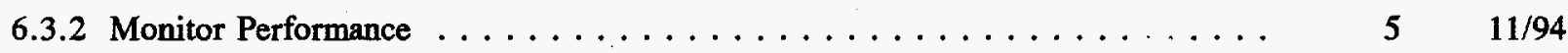

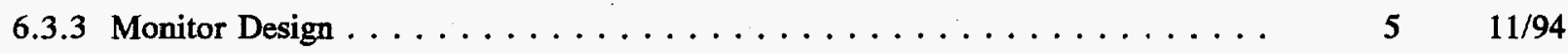

6.3.4 Monitor Operation . . . . . . . . $\ldots \ldots \ldots \ldots \ldots \ldots \ldots \ldots$ 11/94

7.0 Characterization of Current Effluent Monitoring Systems $\ldots \ldots \ldots \ldots \ldots \ldots \ldots \ldots$ 11/94

7.1 Sampling/Monitoring Systems Description $\ldots \ldots \ldots \ldots \ldots \ldots \ldots \ldots \ldots$ 2. $2 \ldots$

7.1.1 Main Stack Particulate Emission Sampling System $\ldots \ldots \ldots \ldots \ldots \ldots \ldots \ldots$. $2 \quad 11 / 94$

7.1.2 Main Stack Radon Gas Emission Sampling System . . . . . . . . . . . . $\quad 7 \quad 7 \quad 11 / 94$

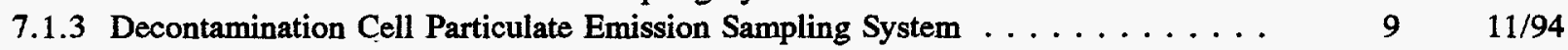

7.1.4 Main Stack Continuous Emission Monitoring System . . . . . . . . . . . . $12 \quad 11 / 94$

7.2 Sampling and Monitoring System Performance $\ldots \ldots \ldots \ldots \ldots \ldots \ldots \ldots \ldots \ldots$

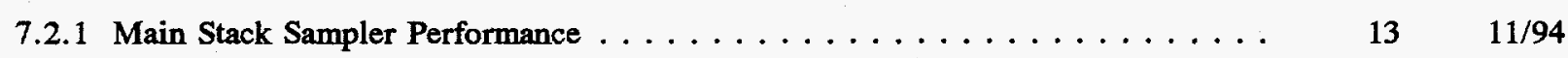

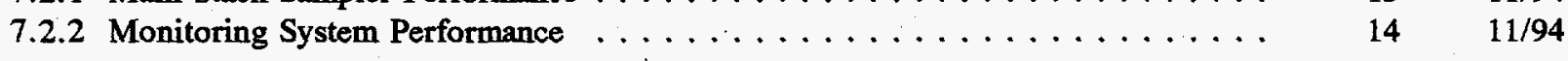

7.3 Handling of Sampling and Monitoring Data $\ldots \ldots \ldots \ldots \ldots \ldots \ldots \ldots \ldots \ldots$. $\ldots \ldots \ldots$ 11/94

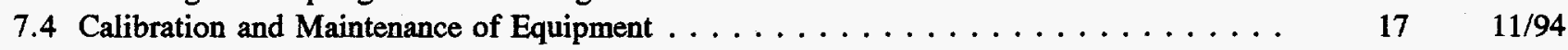

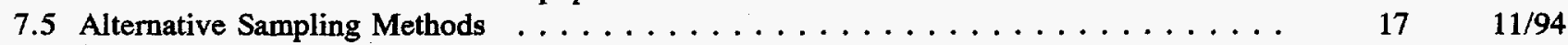

7.6 References . . . . . . . . . . . . . . . . . . . . . . $18 \quad 11 / 94$

8.0 Historical Monitoring/Sampling Data for Effluent Streams $\ldots \ldots \ldots \ldots \ldots \ldots \ldots \ldots \ldots \ldots$ 
8.1 Normal Conditions $\ldots \ldots \ldots \ldots \ldots \ldots \ldots \ldots \ldots \ldots \ldots \ldots \ldots \ldots \ldots \ldots \ldots$

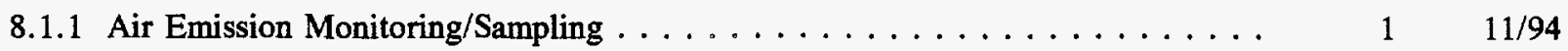

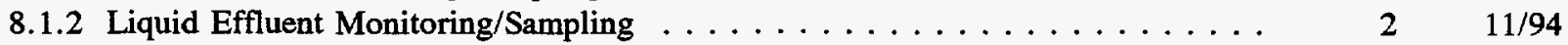

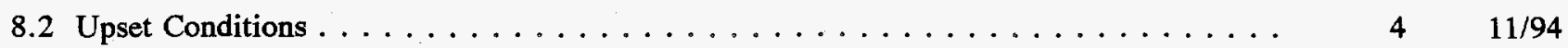

8.3 References . . . . . . . . . . . . . . . . . . . . . . . $6{ }^{11 / 94}$

9.0 Analysis of Effluent Samples $\ldots \ldots \ldots \ldots \ldots \ldots \ldots \ldots \ldots \ldots \ldots \ldots \ldots \ldots \ldots$ 11/94

9.1 Analytical Procedures $\ldots \ldots \ldots \ldots \ldots \ldots \ldots \ldots \ldots \ldots \ldots \ldots \ldots \ldots \ldots$

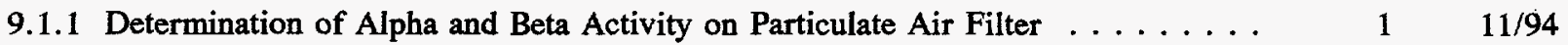

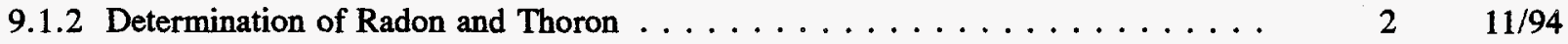

9.1 .3 Isotopic Analysis . . . . . . . . . . . . . . . . . . . 2 2 11/94

9.2 Chain-of-Custody Procedures $\ldots \ldots \ldots \ldots \ldots \ldots \ldots \ldots \ldots \ldots \ldots \ldots \ldots$

10.0 Notifications and Reporting Requirements $\ldots \ldots \ldots \ldots \ldots \ldots \ldots \ldots \ldots \ldots \ldots \ldots \ldots$

10.1 Off-Normal Event Notification and Reporting $\ldots \ldots \ldots \ldots \ldots \ldots \ldots \ldots \ldots$ 11/94

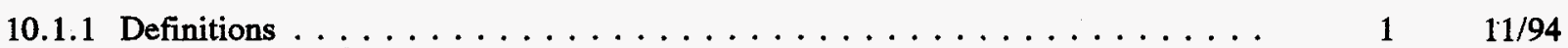

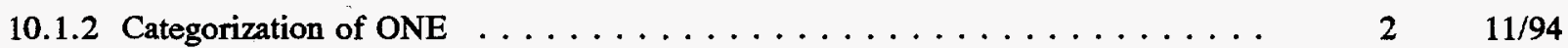

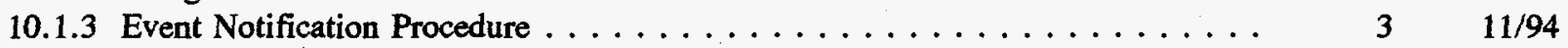

10.2 Periodic Routine Effluent Monitoring Reports $\ldots \ldots \ldots \ldots \ldots \ldots \ldots \ldots \ldots \ldots \ldots$

11.0 Interface with the Operational Environmental Surveillance Program $\ldots \ldots \ldots \ldots \ldots \ldots \ldots$

12.0 Quality Assurance Plan $\ldots \ldots \ldots \ldots \ldots \ldots \ldots \ldots \ldots \ldots \ldots \ldots \ldots \ldots \ldots$ 11/94

13.0 Internal and External Plan Review $\ldots \ldots \ldots \ldots \ldots \ldots \ldots \ldots \ldots \ldots \ldots \ldots$

14.0 Compliance Assessment $\ldots \ldots \ldots \ldots \ldots \ldots \ldots \ldots \ldots \ldots \ldots \ldots \ldots \ldots \ldots$ 11/94

14.1 Basis for Compliance Assessment $\ldots \ldots \ldots \ldots \ldots \ldots \ldots \ldots \ldots \ldots \ldots \ldots$. . . . . . . $11 / 94$

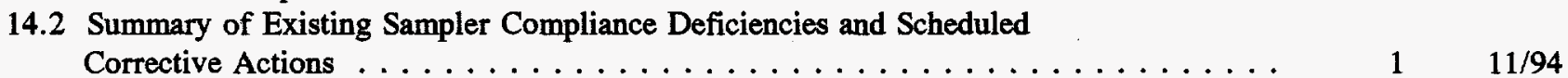

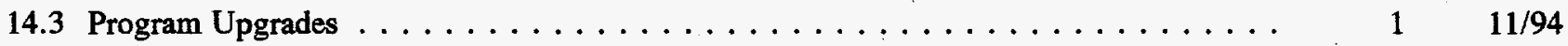

Appendix A - Lab Research and Management Summaries: 327 Facility . . . . . . . . . . $1 \quad 11 / 94$

Appendix B - Projection of Offsite Emission Dose $\ldots \ldots \ldots \ldots \ldots \ldots \ldots \ldots \ldots \ldots$ 11/94

Appendix C - Nonradioactive Hazardous Materials Characterization $\ldots \ldots \ldots \ldots \ldots \ldots \ldots$

Appendix D - Data from Waste Stream Characterization Report $\ldots \ldots \ldots \ldots \ldots \ldots \ldots \ldots$ 11/94

Appendix E - Ventilation System Flow Pathways $\ldots \ldots \ldots \ldots \ldots \ldots \ldots \ldots \ldots \ldots \ldots \ldots$ 11/94 


\section{Figures}

Page No. Date

2.1300 Area Map with the 327 Facility Highlighted $\ldots \ldots \ldots \ldots \ldots \ldots \ldots \ldots$

2.2327 Facility Basic Floor Plans $\ldots \ldots \ldots \ldots \ldots \ldots \ldots \ldots \ldots \ldots \ldots \ldots \ldots$

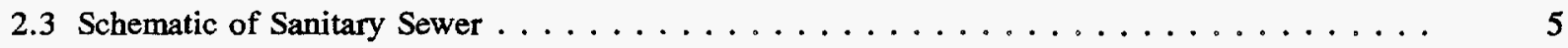

2.4 Schematic of Process Sewer, Retention Process Sewer, and Radioactive

Liquid Waste System $\ldots \ldots \ldots \ldots \ldots \ldots \ldots \ldots \ldots \ldots \ldots \ldots \ldots \ldots \ldots$

4.1 Schematic of the 327 Facility Exhaust System $\ldots \ldots \ldots \ldots \ldots \ldots \ldots \ldots \ldots$

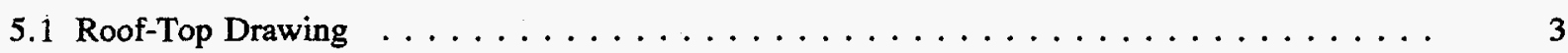

7.1327 Facility Sampling Systems $\ldots \ldots \ldots \ldots \ldots \ldots \ldots \ldots \ldots \ldots \ldots$

7.2327 Facility Sampling Probe Assembly $\ldots \ldots \ldots \ldots \ldots \ldots \ldots \ldots \ldots \ldots$

7.3 Sampling System on 327 Stack $\ldots \ldots \ldots \ldots \ldots \ldots \ldots \ldots \ldots \ldots \ldots \ldots \ldots \ldots \ldots$ 11/94

7.4 Sampling System at Base of 327 Stack $\ldots \ldots \ldots \ldots \ldots \ldots \ldots \ldots \ldots \ldots \ldots \ldots$ 11/94

7.5327 Facility Radon Sampling System $\ldots \ldots \ldots \ldots \ldots \ldots \ldots \ldots \ldots \ldots \ldots \ldots \ldots$ 11/94

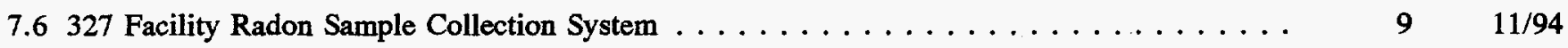

7.7327 Facility Radon Sampling Probe $\ldots \ldots \ldots \ldots \ldots \ldots \ldots \ldots \ldots \ldots \ldots \ldots \ldots \ldots \ldots \ldots \quad 10 \quad 11 / 94$

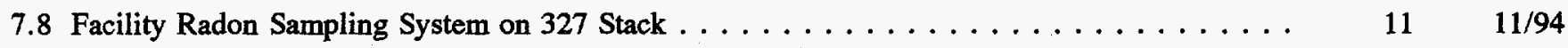




\section{Tables}

Page No. Date

5.1327 Facility Ventilation Exhaust Points $\ldots \ldots \ldots \ldots \ldots \ldots \ldots \ldots \ldots \ldots \ldots \ldots \ldots$ 2 $2 \ldots \ldots$ 11/94

5.2 Volumetric Flow Rate Measurements -327 Main Exhaust $\ldots \ldots \ldots \ldots \ldots \ldots \ldots \ldots$. . . $41 / 94$

5.3 Volumetric Flow Rate Measurements - 327 Facility Decontamination Cell Exhaust . . . . . $\quad 4 \quad 11 / 94$

5.4 Liquid Effluent Discharge Lines $\ldots \ldots \ldots \ldots \ldots \ldots \ldots \ldots \ldots \ldots \ldots \ldots \ldots \ldots \ldots$

6.1 Radionuclide Contributions to the 327 Facility OED Based on

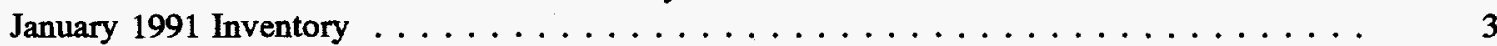

7.1 Airborne Emission Measurements -327 Facility $\ldots \ldots \ldots \ldots \ldots \ldots \ldots \ldots \ldots \ldots \ldots \ldots \ldots$ 1 $11 / 94$

7.2 Detection of Significant Radionuclides in 327 Stack Emissions $\ldots \ldots \ldots \ldots \ldots \ldots \ldots \ldots$. $\ldots \ldots$ 11/94

7.3 Beta-CAM Efficiency and Alarm Levels $\ldots \ldots \ldots \ldots \ldots \ldots \ldots \ldots \ldots \ldots \ldots \ldots \ldots$ 15 $\ldots \ldots$.

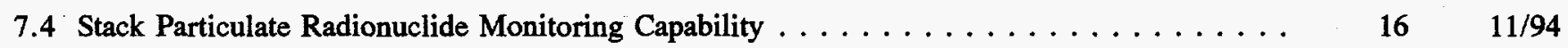

8.1327 Facility Main Stack Sampling Data $\ldots \ldots \ldots \ldots \ldots \ldots \ldots \ldots \ldots \ldots \ldots \ldots \ldots$. $\ldots \ldots \ldots$

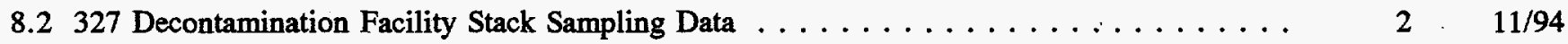

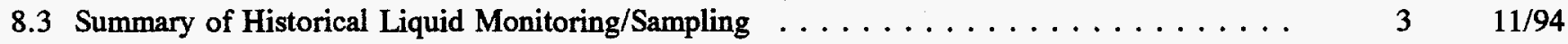

8.4 UOs and ONOs in the 327 Facility $\ldots \ldots \ldots \ldots \ldots \ldots \ldots \ldots \ldots \ldots \ldots \ldots \ldots$. $4 \ldots \ldots$.

9.1 Isotopic Separation and Analysis Methods $\ldots \ldots \ldots \ldots \ldots \ldots \ldots \ldots \ldots \ldots \ldots$ 11/94

10.1 Categorization of Off-Normal Events $\ldots \ldots \ldots \ldots \ldots \ldots \ldots \ldots \ldots \ldots \ldots \ldots \ldots \ldots$ 11/94 


\subsection{Introduction}

It is the policy of the U.S. Department of Energy (DOE) and the Pacific Northwest Laboratory (PNL) to conduct effluent and emission monitoring to determine if the public and environment are adequately protected during DOE operations and whether operations are in compliance with DOE and other applicable federal, state, and local radiation standards and requirements. It is also DOE and DOE contractor policy that effluent monitoring programs meet high standards of quality and credibility.

\subsection{Purpose}

\subsection{Background}

DOE Order 5400.1 on General Environmental Protection Programs gives as the objective for environmental monitoring programs to "demonstrate compliance with legal and regulatory requirements imposed by applicable Federal, State and local agencies; confirm adherence to DOE environmental protection policies; and support environmental management decisions" (DOE Order 5400.1, IV-1). Plans must be prepared for each site, facility, or process that uses "significant pollutants or hazardous materials" (DOE Order 5400.1, IV-2). These requirements are being met through the environmental monitoring program conducted for the Hanford Site and described in the Hanford Site Environmental Monitoring Plan (EMP).

The EMP identifies and discusses two major activities as specified by DOE Order 5400.1: (a) effluent monitoring, and (b) environmental surveillance. Because the Hanford Site contains a number of facilities with effluent monitoring needs, individual effluent monitoring plans are prepared for those facilities to support the discussion of effluent monitoring in the EMP. This report supplies information on effluent monitoring in the 327 Facility.

A Facility Effluent Monitoring Plan (FEMP) was determined to be needed for the 327 Facility because of the quantity of radionuclides in the facility. The FEMP includes action plans and schedules that will be completed in the near term (FY 1995). This includes updating and verifying the effluent lines, sampling liquid effluent streams, upgrading sampling systems (liquid) and monitoring systems (air), and characterization of nonradionuclide emissions.

\subsection{Discussion}

Characterization of the radioactive and nonradioactive constituents present in inventory and in waste streams provides the underlying rationale for sampling and monitoring programs. Currently, sampling and monitoring efforts are confined to radioactive air. Compliance assessments of the existing radioactive air monitoring equipment are included in this FEMP. Compliance sampling for liquid streams is conducted by Westinghouse Hanford Company (WHC).

A major activity of the FEMP effort is to verify all the liquid and air release pathways (e.g., verify all access points to the various sewers and all radioactive emission release pathways under normal operations and during process upset conditions). This plan also identifies effluent monitoring deficiencies and action plans for installation of additional effluent monitoring equipment so that characterization can be completed.

The method of characterization discussed in this plan identifies potential pollutants at the point of generation, and potential upset conditions that are likely to occur, and evaluates the potential for those materials to enter an effluent stream. 


\subsection{Facility Mission and Description}

\subsection{Facility Mission}

The Post-Irradiation Testing Laboratory (327 Facility) provides office and laboratory space for PNL scientific and engineering staff conducting multidisciplinary research in the areas of post-irradiated fuels and structural materials. The facility is designed to accommodate the use of radioactive and hazardous materials in the conduct of these activities. The facility is occupied by staff from the PostIrradiation Testing Laboratory. Distribution of the funding sponsors is Hanford contractor support (85\%), and other (15\%). The primary sponsors include support for K Basin Spent Nuclear Fuel Characterization, Waste Tank Core Sampling, Fast Flux Test Facility Programs, EBR-II Test Facility Programs, and Space Power Program Termination. Other sponsors include support for Japanese reactor research, medical isotope recovery, and materials studies for the Naval Department.

\subsection{Geographical Location and Physical Description}

The Post-Irradiation Testing Laboratory is located in the 300 Area. The facility is adjacent to the 328 Facility to the south, the 326 Facility on the southwest, and California Street to the east (see Figure 2.1).

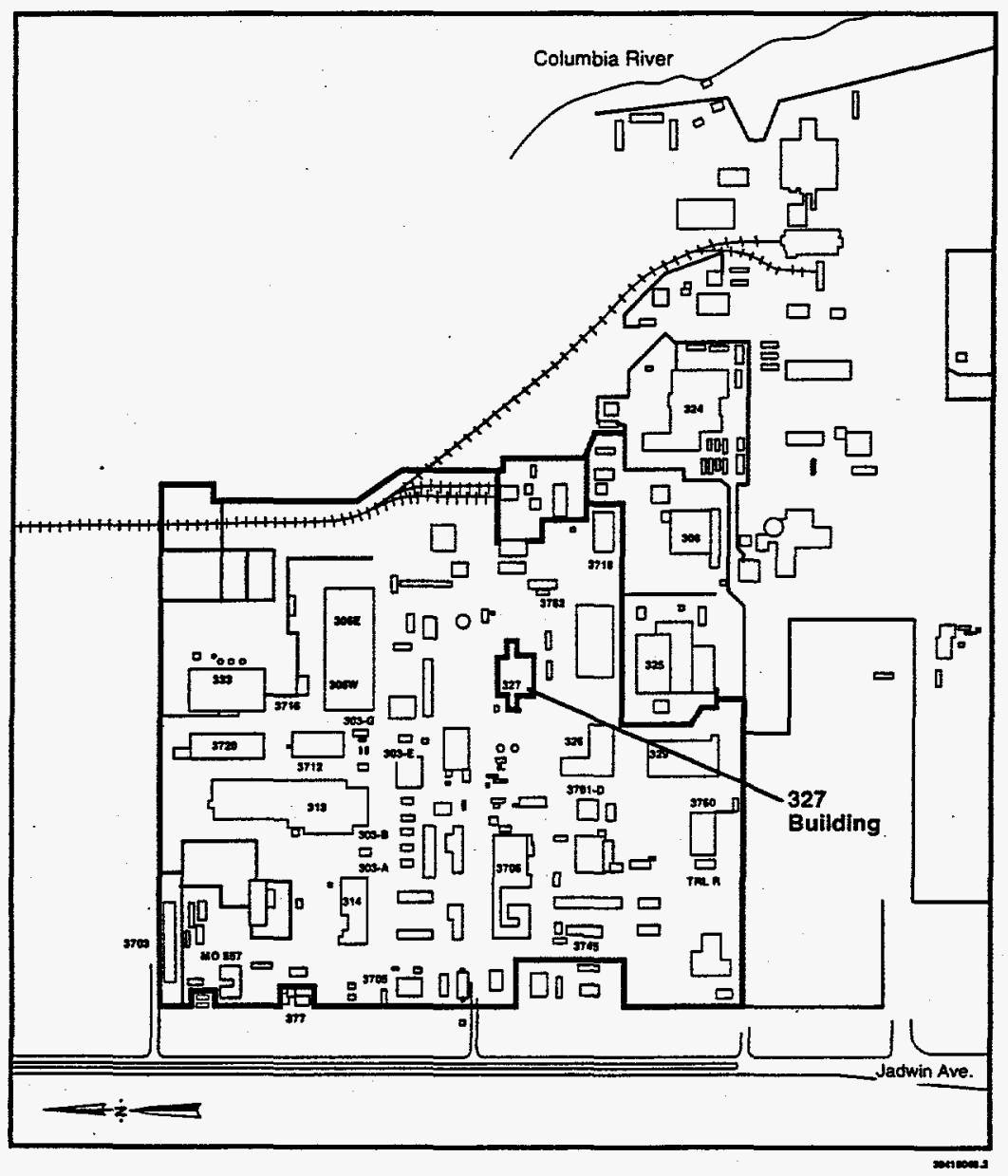

Figure 2.1. 300 Area Map with the 327 Facility Highlighted 
The facility $\left(2,340 \mathrm{~m}^{2}\right.$ or $\left.25,200 \mathrm{ft}^{2}\right)$ is single story with a partial basement. The facility framework is welded steel. The roof is a steel deck covered by a loosely laid ballasted membrane with a gravel finish. The exterior walls are fluted steel insulated panels. The first floor is reinforced concrete or steel decking with painted concrete. The facility has $930 \mathrm{~m}^{2}\left(10,000 \mathrm{ft}^{2}\right)$ of laboratory and work areas, $200 \mathrm{~m}^{2}\left(2,100 \mathrm{ft}^{2}\right)$ of offices, and $220 \mathrm{~m}^{2}\left(2,400 \mathrm{ft}^{2}\right)$ of storage areas along with $980 \mathrm{~m}^{2}\left(10,500 \mathrm{ft}^{2}\right)$ of common areas containing ventilation and auxiliary equipment. The basic floor plan of the facility with the relevant functional systems is depicted in Figure 2.2.

The facility has a ventilation system and protection from fire by a wet pipe sprinkler system. Supply ventilation units are located in the basement, the west end of the canyon in the transfer (truck lock) and storage area, and the northwest storage area of the canyon. Facility emergencies are covered by three systems: fire gongs, evacuation sirens, and criticality horns. The facility is provided with continuous monitors for air activity, radiation, and criticality. The hot exhaust system takes air from all high-contamination areas such as shielded cells, fume hoods, and dry storage, and filters the air through a roughing filter, two highefficiency particulate air (HEPA) filters, and then through a nuclear-grade, activated charcoal filter bank before the effluent air is released. The main electrical service to the facility is supplied by a 500-kVA transformer. Emergency power is supplied by a diesel-driven generator in the 3621-B Facility through a 300-kVA transformer. Emergency power is provided for hot exhaust fans, the radioactive liquid waste system (RLWS) pump, all radiation monitors and alarms, the public address system, the SERF cell, the cranes, the exit lights, and some emergency lights. Other standard safety features incorporated into the facility include fire extinguishers, safety showers, eyewash units, and spill control kits.

Radiation monitoring is accomplished through the use of personnel contamination monitors (PCM), hand and foot monitors, radiation area monitors (RAMs), continuous air monitors (CAMs), and portable instrumentation. Stack effluent monitoring consists of weekly collection of filter cartridges that are subject to radiological analysis. Another portion of the stack exhaust is continuously monitored for the concentration of radiohalogen gases and particulates containing fission product activity and plutonium. The monitors alarm when the activity reaches $500 \mathrm{dpm}$ for alpha or $4,800 \mathrm{dpm}$ for beta and gamma radiation.

This facility has four aqueous effluent systems that consist of the sanitary sewer (SNS), process sewer (PS), retention process sewer (RPS), and RLWS. The SNS (shown in Figure 2.3) serves only the change room, lunchroom, and office areas that have no potential for contamination. The SNS waste is discharged into the 300 Area SNS system operated by Westinghouse Hanford Company (WHC). The PS (Figure 2.4) also removes liquids with no potential for radioactive contamination and serves the ventilation supply scrubbers. It discharges to the 300 Area PS system, operated by WHC. The RPS, which is normally free of contamination but has a potential for such contamination, is connected to cooling water drains, floor drains, and laboratory chemical waste water systems. The RPS (Figure 2.4) drains to a sump within the basement equipment room where a monitored valve would divert contaminated liquids to the 300 Area RLWS, but the RPS normally flows to the PS system. The RLWS is shown schematically in Figure 2.4. The RLWS serves areas with high potential for contamination. A sump and pump system is provided in the basement to serve the areas that are below the level of the RLWS main. These liquids are released to the 340 Facility for collection, processing, and disposal. 


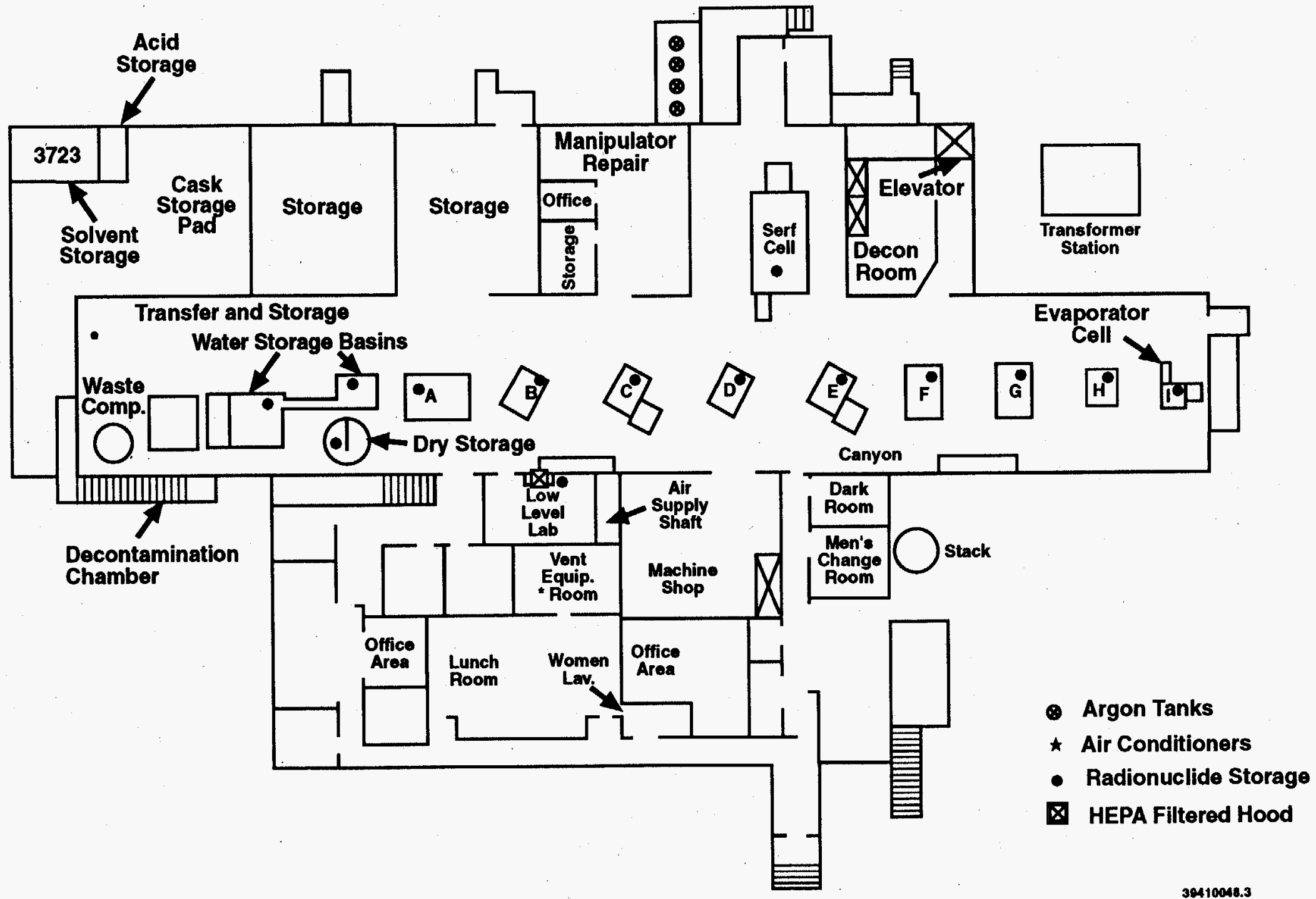

Figure 2.2. 327 Facility Basic Floor Plans 


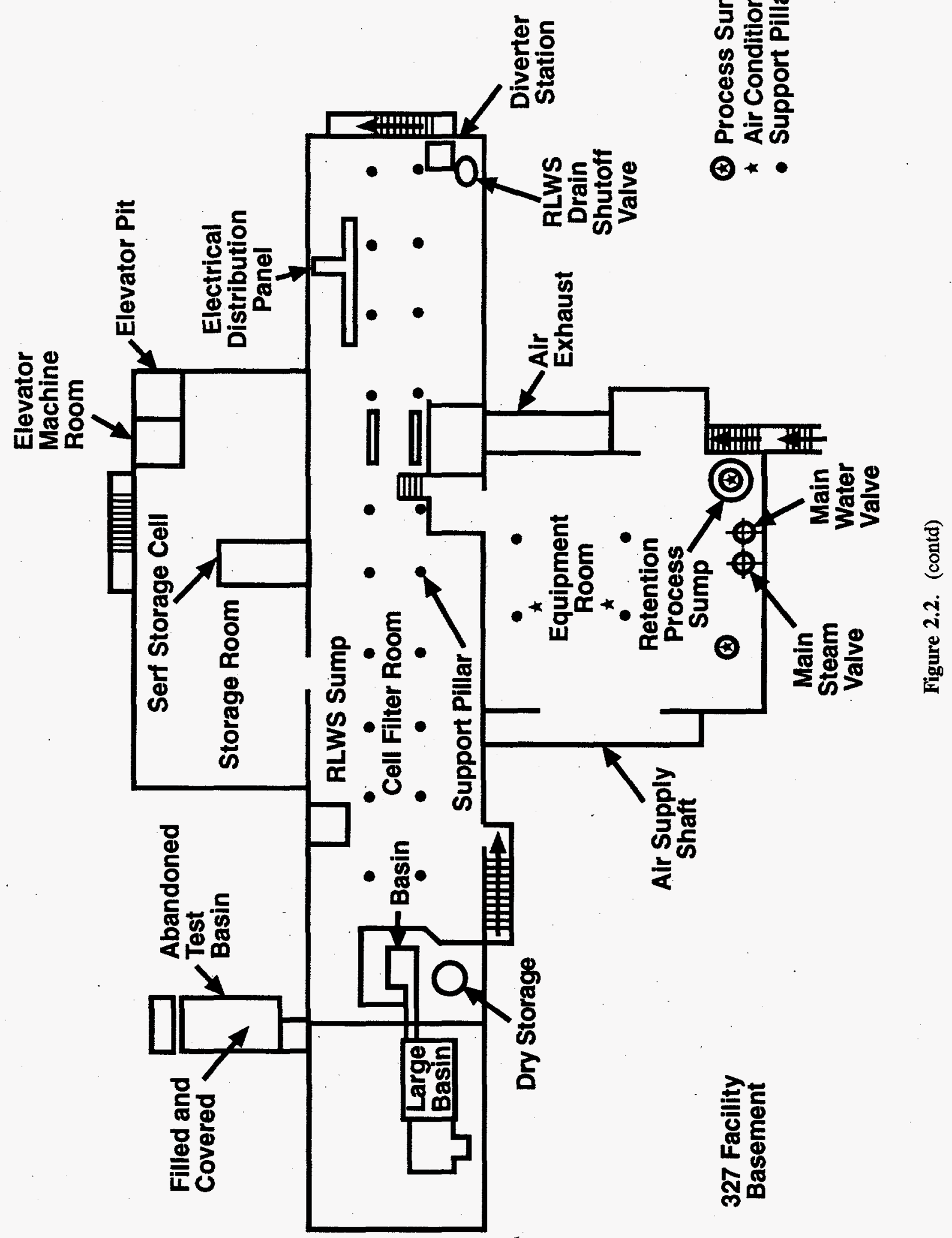




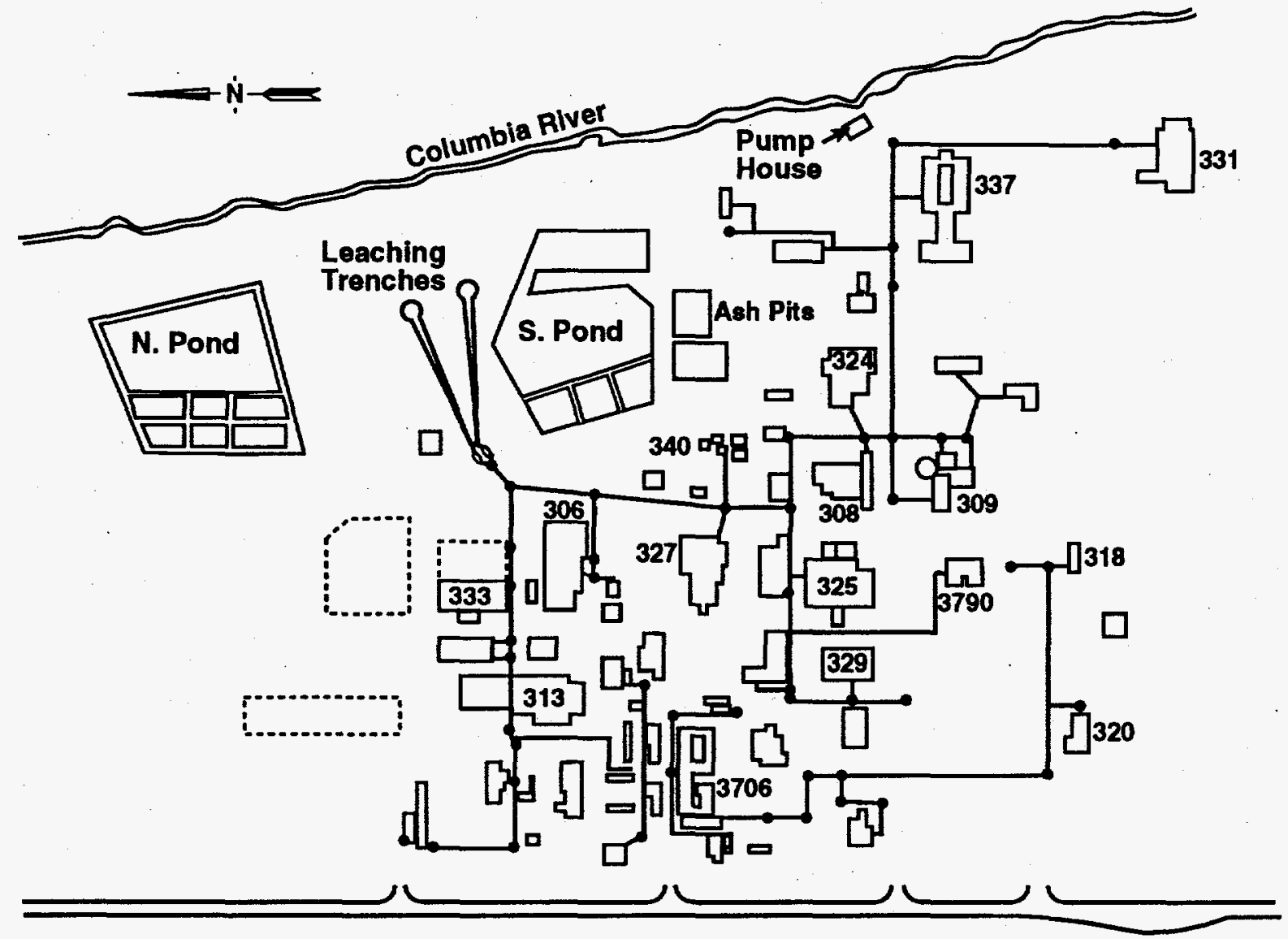

39410048.4

Figure 2.3. Schematic of Sanitary Sewer

\subsection{Brief Process Description}

The primary facility processes that generate solid, liquid, and gaseous effluent are associated with the conduct of testing and metallurgical examinations for supporting sponsors. Examinations and testing performed by staff located in the facility include the following:

- gas collection, precision sectioning, metallography, remote machining, alkaline metal reaction, isotope recovery, medical isotope processing

- specimen/equipment cleaning and decontamination

- irradiated materials preparation and testing 


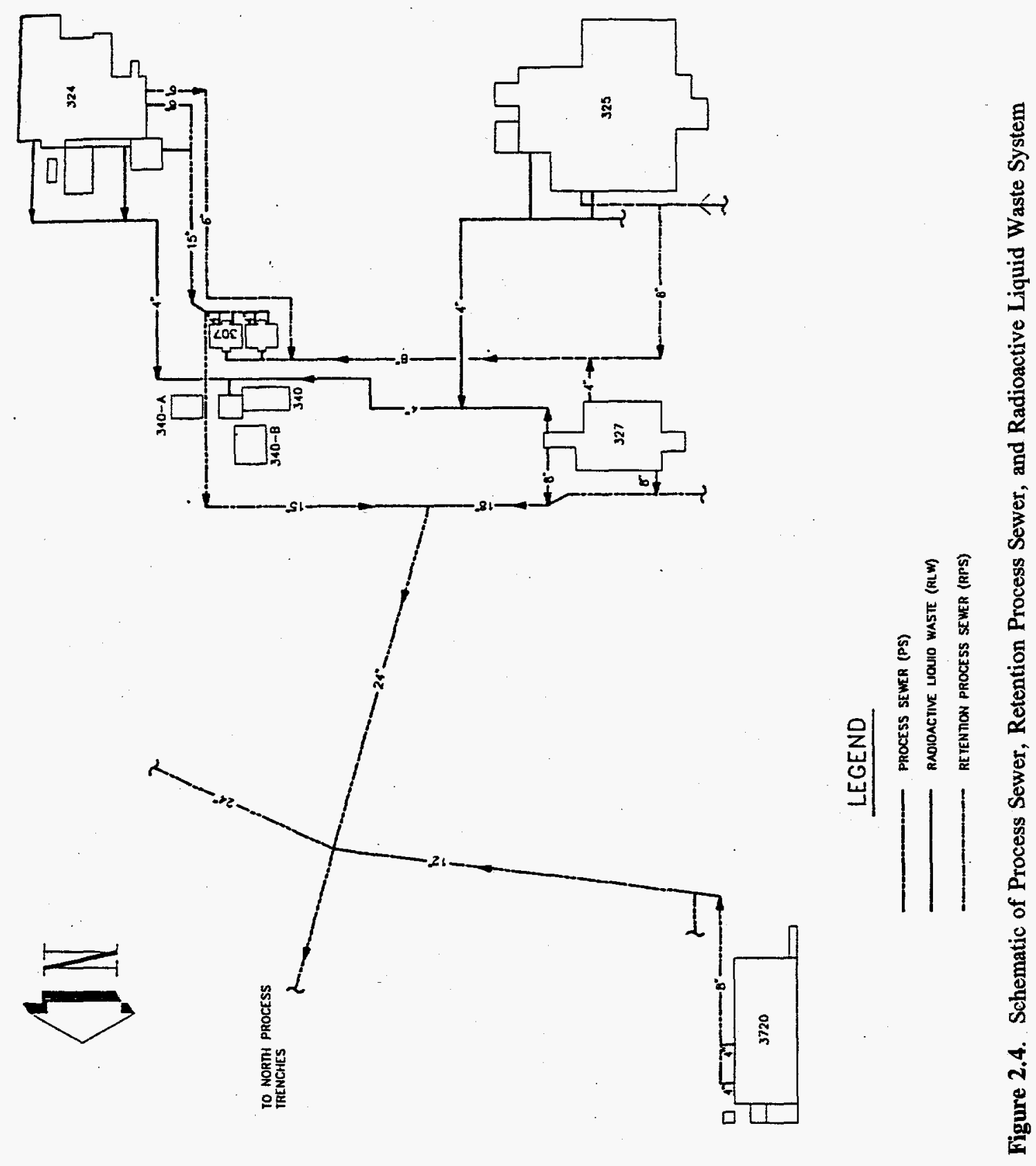


- remote assembly of irradiated components

- radioactive waste management

- shipping and receiving radioactive shipments.

Processes associated with Facility operation that could potentially result in such discharges include 1) stored radionuclides or chemicals and their usage; 2) liquid waste accumulation and storage; 3) programmatic sample storage; 4) research implementation (e.g., use of gloveboxes and hot cells); and 5) facility operations. Process evaluation was targeted at the process ventilation (HEPA, radioactive halogen filters) system, compressed gas storage, and pump systems for condensate return, vacuum and air sampling. Each of these source terms will be addressed relative to the 327 Facility programmatic activities and/or operations.

\subsection{Source Term Definition and Description}

For the purpose of this section, a source term is a description of the nature and location of potential releases of radioactive and/or chemical materials within a facility to the atmosphere, the PS, the RPS, or the RLWS due to process activities.

Figure 2.2 identifies locations in the facility where radionuclides may be found. Research activities are conducted primarily in the hot cells which are areas of potential source terms associated with the conduct of research in the 327 Facility that could lead to releases of pollutants to the RLWS, or the ventilation system. Brief summaries of research and laboratory activities for each hot cell, lab, or area in the 327 Facility are provided in Appendix A.

Research is performed on irradiated fuels and other structural materials. Experiments are conducted within hot cells, while decontamination takes place primarily in hot cells or fume hoods. Due to the dynamic activity of this facility, the activities within the cells or other work areas are subject to change. Strict administrative controls are carried out within the guidelines of PNL-MA-50, PNL Operation Manual. PNL-MA-540, Operation Manual for the 327 Building, provides specific operating procedures but will not exclude the guidelines set by PNL-MA-50. A material balance is maintained according to the guidelines of PNL-MA-5, Nuclear Material Control and Accountability. Liquid or solid wastes are disposed according to PNL-MA-8, Waste Management and Environmental Compliance.

Appendix B summarizes the nature of the radionuclide inventory. Most of the inventory is in the form of solids - irradiated fuel, cesium capsules, and structural material. . Very little is considered easily dispersed although fines may be generated during machining operations. The primary airborne release from research activities is the evolution of radon and thoron gases from medical isotope processing. The inventory method used in Appendix B does not account for gases generated during processing. Because of this deficiency in the method, project specific estimates are made on potential releases to the ventilation system for projects in which gases may be generated.

An evaluation was made of the nonradioactive hazardous materials stored in the 327 Facility. A summary of this evaluation is provided in Appendix C. 


\subsection{Applicable Regulations}

\subsection{Introduction}

\subsection{Environmental Regulations}

\subsubsection{Federal Clean Air Act}

Among the primary concerns of PNL management and staff are compliance with federal, state, and local regulations; DOE Orders; and the protection of the environment and public health. PNL's FEMPs support overall compliance and are intended to ensure liquid effluents and air emissions by the Laboratory conform to all applicable standards. This chapter provides a brief description of those standards. This material is intended to assist staff in gaining fuller understanding of those regulations that drive environmental compliance and better appreciation for the significance of noncompliance. Instances of noncompliance could result in violations of the law and imposition of fines or penalties on the Laboratory and/or individual staff members, and possible criminal action against the Laboratory and/ or individual staff members for willful neglect.

This section identifies the major environmental laws (federal and state) that guide PNL in implementing environmental protection policies with respect to air emissions and liquid effluents.

Most major federal environmental laws contain specific language defining their applicability to federal facilities and specifying the requirements for federal facilities to comply with certain state and local pollution-control regulations. Both federal and state laws are passed by act, statute, or executive order. Regulations are then prepared by an authorized agency, federal regulations are documented in the Code of Federal Regulations (CFR), and state regulations are documented in the Washington Administrative Code (WAC). In addition, policy and "guidance" documents are written, many of which must be strictly followed. A regulatory program is then often composed of the act, CFR or WAC, and written guidance. Federal regulations are often incorporated directly by reference into programs, or states implement their own, often more stringent, regulations. DOE Orders often use federal regulations as bases or may reference those regulations for compliance.

The Clean Air Act (CAA) of 1970, and its 1977 amendments established national ambient air quality standards and mechanisms for attaining and maintaining those standards. It also established standards and mechanisms for preserving air quality in areas already cleaner than the standards. The original CAA consisted of three titles. The Clean Air Act Amendments (CAAA) of 1990 greatly expanded the scope of the act consisting of eleven titles. Some of the titles amend the three earlier titles and others are new. Regulations implementing the amendments have been, and will continue to be, promulgated for several years.

Regulations implementing the amended act that are applicable to current PNL operations and that require emission monitoring include 40 CFR 61, "National Emissions Standards for Hazardous Air Pollutants, Subpart H National Emission Standards for Emissions of Radionuclides Other Than Radon from Department of Energy Facilities." The requirements of this regulation are discussed below. The State Department of Health (WDOH) has applied to the U.S. Environmental Protection Agency (EPA) for delegation of authority to implement this regulation. 


\subsubsection{NESHAPs}

\subsubsection{The Washington State Clean Air Act (WCAA)}

The WCAA empowers Ecology to develop, implement and enforce state air regulations. State air regulations are contained in the Washington Administrative Code (WAC-173-400 series). WAC 173-400, "General Regulations for Air Pollution Sources, " would impose monitoring and control requirements for new or modified sources. Also, WAC 173-460, "Controls for New Sources of Air Pollutants," is applicable to NESHAPs-regulated emission units and could also require the application of TBACT for new or modified sources of air pollutants. WAC 173-401, "Operating Permit Regulation," when approved by the EPA as implementing CAAA Title $\mathrm{V}$, may result in monitoring requirements as a permit condition, as discussed above. A related state regulation, WAC 246-247, "Regulation of Radioactive Air Emissions," requires monitoring of radioactive emissions incorporating the requirements of 40 CFR 60, Subpart $H$.

\subsubsection{Clean Water Act}

Section 313 of the Clean Water Act (PL 92-500, 33 USC 1251, et seq.) requires federal facilities to obtain a national pollutant discharge elimination system (NPDES) permit to ensure that all appropriate discharges into "navigable waters" are within applicable water quality standards and technology-based requirements 
(see Section 3.2.6 below). Currently, the Laboratory operates under two site-wide NPDES permits for its five outfalls in the 300 Area and one outfall in the 100 Area.

The 327 Facility releases liquid effluent to 300 Area sewer and waste systems operated by WHC. None of these systems are currently under an NPDES permit. However, future plans for the PS include treatment and discharge to the Columbia River for which an NPDES permit will be required.

\subsubsection{WAC 173-220, "National Pollution Discharge Elimination System Permit Program"}

WAC 173-220 implements authority delegated from EPA to Ecology to issue NPDES permits under the Federal Water Pollution Control Act (FWPCA) amendments of 1972. Permits under this program are required for the direct discharge of pollutants or other waste or substances from a point source into any navigable water of the state. The term "point source" includes any discrete conveyance, such as a ditch, pipe, well, container, or vessel from which pollutants may be discharged. "Pollutant" is defined broadly to include everything from sand to chemical, biological, and radioactive materials, and industrial, municipal, and agricultural waste. "Navigable waters" is defined very broadly to include all surface waters of the state. The term is not limited to waters that are, in fact, navigable. "Navigable waters" do not, however, include groundwater.

Permits under this program include effluent limitations, schedules of compliance, monitoring requirements, reporting requirements (including a requirement to report any new or increased discharge of pollutants), and any conditions necessary to prevent or control pollutant discharges. Effluent limitations may be based on federal technology-based standards or on "any more stringent limitation" imposed by state law, including applicable water quality standards or methods necessary to provide all known, available, and reasonable technologies (AKART) that exceed the requirements of federal law. Section 510 of the FWPCA reserves to the states the ability to promulgate additional effluent or treatment standards so long as they are at least as stringent as the federal standards.

As stated in the previous section, future plans for the process streams from the 327 Facility and other 300 Area facilities include treatment and discharge to the Columbia River; thus an NPDES permit will be required for the discharge.

\subsection{DOE Orders}

A number of DOE Orders establish the framework for environmental safety and health and environmental compliance by DOE and its contractor operations. These orders are essentially policy statements internal to DOE by which it commits operating contractors, such as PNL, to full compliance with all applicable federal, state, and local environmental standards. DOE Orders are essential components of PNL's environmental compliance program. The following are brief descriptions of major DOE Orders driving overall environmental compliance, including the development of FEMPs.

\subsubsection{DOE 5400.1, "General Environmental Protection Program"}

This order establishes environmental protection program requirements, authorities, and responsibilities for DOE operations to ensure compliance with all applicable federal, state, and local environmental protection laws and regulations, executive orders, and internal DOE policies. This order enumerates DOE's 
overall policy commitment to environmental compliance, as well as more specific commitments to a number of substantive objectives, including notification and reports for effluent releases, environmental protection program plans, and environmental monitoring requirements.

The development of FEMPs is driven by Chapter IV of this order, "Environmental Monitoring Requirements, " which states:

A written environmental monitoring plan shall be prepared for each site, facility, or process that uses, generates, releases, or manages significant pollutants or hazardous materials.

\subsubsection{DOE 5400.5, "Radiation Protection of the Public and the Environment"}

This DOE Order establishes standards and requirements for operations of DOE and DOE contractors with respect to protecting of the public and the environment against undue risk from radiation. Airborne emissions are limited to the extent required by the CAA and its amendments. Accordingly, exposing members of the public to radioactive materials released to the atmosphere as a consequence of routine DOE activities shall not cause members of the public to receive, in a year, an effective dose equivalent (EDE) greater than $10 \mathrm{mrem}(0.1 \mathrm{mSv})$.

DOE makes further provision for emissions and exposure to ${ }^{200} \mathrm{Rn},{ }^{222} \mathrm{Rn}$, and their respective decay products. These guidelines extend beyond federal guidelines in 40 CFR 61 and state guidelines in WAC 173-480 that explicitly exclude doses caused by these radionuclides.

\subsubsection{DOE EH-0173T, Environmental Regulatory Guide for Radiological Monitoring and Environmental Surveillance}

This document is significant because it provides guidance for DOE Orders concerning environmental safety and health and sets conditions for radiological emissions. DOE mandates that all airborne emissions be monitored and evaluated and potential for release of radionuclides be assessed. Furthermore, any airborne emissions that have the potential for causing doses exceeding 0.1 mrem EDE from emissions in a year shall be monitored in accordance with requirements set forth in DOE 5400.1 and 5400.5.

\subsection{PNL-MA-8, Waste Management and Environmental Compliance}

This document is an internal PNL guide to regulatory compliance. It is intended to supplement, not replace, compliance with applicable regulations and DOE Orders. PNL-MA-8 sets forth procedures and requirements that must be met for air and liquid discharges in the 300 Area. 


\subsection{Effluent Stream Characterization}

During normal operations, the effluent streams from the 327 Facility can contain source terms from a variety of research and development activities. Shutdown operations produce a small subset of the normal operating source terms. In addition, potential upset conditions must also be considered. These are nonroutine situations that would be expected to occur under normal operations. An upset could result in either an unusual release that follows a normal effluent pathway or a normal release that follows an unusual pathway. Unusual releases that follow unusual pathways are considered accidents and are discussed in the 327 Facility Safety Analysis Report (SAR).

The purpose of this section is to identify those effluent streams that require sampling and/or monitoring and the nature of the contaminants to be monitored. The determination of the need to monitor is based on the facility inventory available for release under the conditions cited above, the pathways available for discharge of materials, and regulatory requirements. These have been previously discussed in Sections 2.0 and 3.0.

\subsection{Identification of Effluent Pathways}

The 327 Facility produces both liquid effluent streams and airborne emissions, all of which are generated in the facility rather than being pass-throughs from other facilities. The effluent and emission streams during normal and shutdown operations include three sewers, one ventilation stack, and one decontamination cell stub stack. The liquid effluent streams are not released directly to the environment, but are released to the 300 Area effluent systems operated by WHC.

\subsubsection{Gaseous and Aerosol Emission Pathways}

Figure 4.1 provides a simplified summary of the 327 Facility exhaust system. Greater detail can be found in the schematics in Appendix E. These drawings were prepared and field verified in the summer of 1991 and verified again in 1994. They have been identified as critical facility drawings. Any facility modification that changes facility flow paths 1) must receive prior concurrence of the facility manager (per PNL-MA-8, 1991 revision), and 2) requires updating of the appropriate drawing prior to project close-out.

Almost the entire 327 Facility is in one ventilation zone, within which air balance keeps flow moving from "clean" to "dirty" areas and from the atmosphere into the facility. Some confinement is also provided by conducting high-inventory operations in hot cells. There are no process off-gas systems. All potentially radioactively contaminated air flow passes through at least one stage of HEPA filtration before leaving the facility through a monitored and sampled stack. 


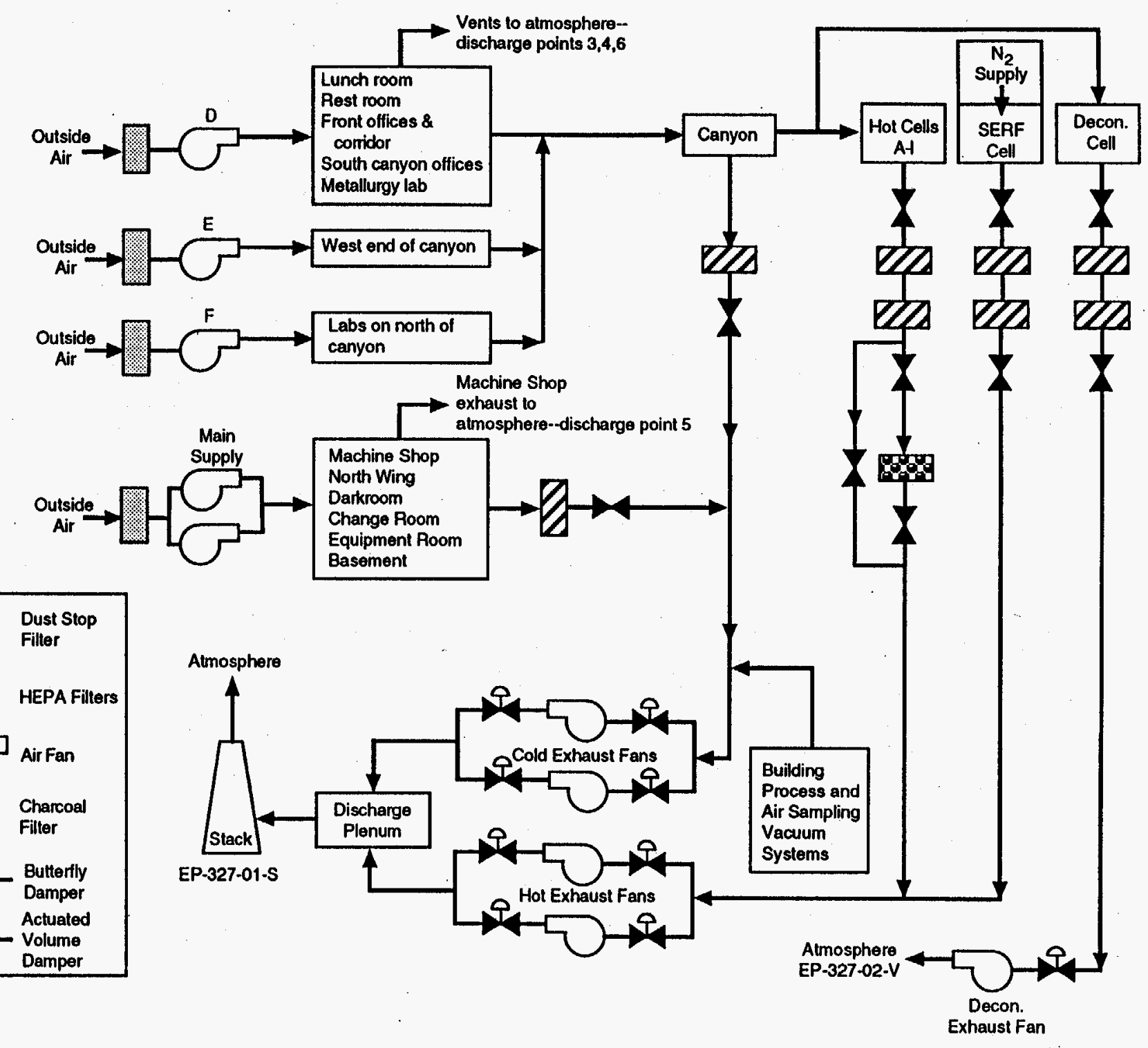


Supply

Exhaust

Vents
The following sections discuss the air flows from supply and through the exhaust stack and the vents. These descriptions are intended to support later descriptions (Section 4.3) of effluent release paths under normal and upset conditions.

Two main supply fans (with no standby) using $100 \%$ outside air provide supply air to the majority of the 327 Facility, as shown in Figure 4.1. The hot cells in the canyon do not have a separate air supply, but draw in air from the canyon through various leak paths. The SERF (or prep) Cell and the Storage Cell are supplied with nitrogen; like the other hot cells, they are maintained at belowcanyon pressure.

Smaller supply systems serve some parts of the facility, such as the transfer and storage area in the west end of the canyon; the southern, clean part of the facility, including the lunch room, front offices, south canyon offices, and metallurgy laboratory; and a room on the north side of the canyon.

During normal operation, the exhaust systems provide the only path followed by in-facility releases. The exhaust systems are described in this section. As shown in Figure 4.1, all air flow from the hot cells and dry storage is handled by the hot exhaust system (system C). This air passes through two stages of HEPA filtration and one stage of potassium-iodide-impregnated charcoal filtration (charcoal filtration is required via an OSR when more than $0.1 \mathrm{Ci}$ of radioiodine are in a cell) before exiting the facility through the main stack. A separate set of HEPA filters is used for each hot cell, but the charcoal filters are common to all except the Serf cell and the decontamination cell. The decontamination cell has its own stub stack and separate hot exhaust system (system G) that employs two stages of HEPA filtration. Air from the canyon, surrounding rooms, and the basement is exhausted by the cold exhaust system (system B). This air passes through one stage of HEPA filtration before the stack. The offices, lunchroom, restrooms, process vacuum system, and facility air sampling vacuum system also exhaust to the stack through the cold exhaust system, but with no HEPA filtration.

One exhaust fan (with a second on standby) exhausts air in the hot exhaust system. The machine shop and the decontamination chamber each have their own exhaust fan. Two fans (with no standby) are used for the cold exhaust system. These fans, except for the decontamination chamber fan, are all part of systems that discharge through the stack. There are also two small exhaust fans that discharge to roof vents, one for the rest rooms and one for the lunch room.

Both of the hot exhaust fans are connected to the emergency power system and have an automatic switch-over feature that activates the standby fan if the online fan malfunctions. The supply, cold exhaust, and hot exhaust fans are interlocked such that the hot exhaust fan cannot switch over or shut down without shutting down the cold exhaust fans. In turn, shut down of the cold exhaust fans causes shut down of the supply fans.

Most of the air vents in the 327 Facility can be considered to be part of the ventilation exhaust system, and as such have already been discussed. The remaining vents do not serve areas where chemicals or radioactive materials are stored or used. These include the equipment room relief vent, the front corridor ventilator, 


\subsubsection{Liquid Effluent. Pathways}

Sanitary Sewer the elevator shaft vent, the sewer system vents, and other pathways that can be produced by potential air balance problems.

The front corridor roof ventilator and the equipment room relief vent could be exit points for radioactive releases only if radioactivity was released from the hot cells and (as a result of the same failure) "backed up" into the corridor and office area. This situation is considered beyond what is likely to occur and is beyond the scope of this document.

The elevator shaft vents to atmosphere during normal operations when the elevator is moving upward in the shaft. Upset source terms of regulated material are unlikely to be released into and through the elevator shaft because the shaft is generally at a less negative pressure than the surrounding part of the facility.

The only sewer systems that vent to atmosphere are the PS and the SNS. The sewer vents are unfiltered but sealed off from facility atmosphere by liquid loop seals. An upset might cause a release to room air, a small part of which could then be entrained into the PS by concurrent liquid flow into the drain. In addition, small amounts of aerosol might be resuspended or vapor evaporated from the liquid contents of a process sewer line contaminated by an upset. However, these hypothetical drain paths are regarded as being implausible pathways for any significant release of regulated material.

Normal facility leak paths may also act as vents in extreme conditions. At average wind speeds, the normal air balance and pressure gradient ensure that all flow goes out the final exhaust plenum and stack, even if doors or the truck lock or smaller leak paths are open. The facility pressure is maintained at about 0.02 in. water negative (or $5 \mathrm{~Pa}$ negative) with respect to the atmospheric pressure measured on the roof. This same range of lower than roof pressure may be found on the sides of a flat-roofed facility at wind speeds of $4.5 \mathrm{~m} / \mathrm{s}(10 \mathrm{mph})$ or greater. Thus, flow might leave the facility through normal leak paths on the sides of the facility that are parallel to a high wind. Such hypothetical situations may occur during normal operations, but could only produce releases if an upset source term had escaped its local containment (e.g., hot cell). Only a small part of the air flow in the facility could escape in this manner.

Four liquid waste systems serve the 327 Facility: the SNS, PS, RPS, and the RLWS. The following sections describe the liquid effluent paths in the 327 Facility. This description is believed to be accurate, but is preliminary for the SNS and PS; the "as-built" drawings for these systems are not yet completed. The "as-built" drawings for the RPS and RLWS were completed in 1994.

The 327 Facility SNS serves only the lunchroom, water fountains, toilets, change areas, and other water uses in which no contamination is believed to be possible. Under normal operating conditions, no regulated materials are present in the SNS effluent. There are no connections between the SNS and any other liquid effluent stream or process water.

Process Sewer and Retention Process Sewer

The PS carries cooling water from the facility HVAC system and other nonsanitary liquid waste that does not contain regulated materials. Throughout most of 
Radioactive Liquid Waste System

\subsection{Facility Inventories}

\subsubsection{Radionuclides}

its length, the RPS is separate from both the PS and the RLWS. It drains normally nonradioactive water from parts of the basement, the machine shop, and the canyon, water systems that are normally free of radioactive contamination but have the potential for such contamination.

Normally the RPS effluent flows into the 307 basins operated by WHC, then to the PS system also operated by WHC. When the RPS contains more radioactivity than $5 \times 10^{-5} \mu \mathrm{Ci} / \mathrm{ml}$ of ${ }^{137} \mathrm{Cs}$, a gamma radioactivity monitor in the facility automatically operates a three-way valve and diverts RPS flow into the RLWS, which is intended to contain radioactivity. If diversion does not occur, the 327 Facility RPS wastes are discharged to the 307 basins where they are screened again for radioactivity. From the 307 basins the effluent is transferred to the 300 Area PS or, if diverted, the liquid goes to the 300 Area RLWS.

The RLWS serves the hot cells, fume hoods, decontamination cell, dry storage, and the portions of the basement that have high contamination potential. A sump and pump system in the basement serves the areas that are below the level of the RLWS main. The RLWS sump is doubly contained and includes a leak detection system, two float-controlled pumps, and high-liquid alarms.

The RLWS wastes are transferred after approval from WHC to the 340 Facility Waste Management Facility operated by WHC under contract with DOE. Transfer is accomplished by jetting the waste via the 300 Area RLWS line, a doublecontainment pipe with a leakage alarm.

The facility and local inventories of radionuclides and hazardous chemicals are important to effluent characterization because of their potential for release. The chemical inventories in the 327 Facility (and the associated small storage facility 3723) are discussed in Appendix C. This section provides information on the types and forms of radionuclides in the facility under current and foreseen operations.

Because 327 Facility is primarily intended for irradiated fuel and metal research, the radionuclides found in the facility include transuranics, uranium, mixed fission products (MFPs), and activated metal. The radionuclides in the facility are primarily in solid or metal form, although small amounts of fines may be generated by cutting and grinding operations, and small amounts of contaminated etchant solutions may be produced by etching. In addition, medical isotope production has been performed resulting in the emission of radon and thoron gases. Appendix $B$ lists the amounts and forms of radionuclides in the facility for current and near-future operations.

In-process radionuclides are only found inside hot cells, unless the radionuclides are in sealed sources. Aside from nuclides that are in process or potentially so, the facility also contains materials stored for future use. Finally, an indeterminate but probably small inventory of assorted radionuclides is believed to be present as "holdup" in HEPA filters and plated deposits in ventilation ducts and liquid pipes.

Note that the quantities of radionuclides listed in Appendix B are the total amounts of each in the facility, summed over all the inventory items (samples, fuel pellets, pins) in the facility. Each of the physical inventory items, being irradiated fuel or metal, may contain many of the isotopes shown. 


\subsection{Characterization of Source Terms Contributing to Effluent}

\subsubsection{Potential Air Emissions}

Normal Operations
The characteristics of source terms that could contribute to each effluent stream during normal operating, shutdown, and upset conditions are described in this section. Source terms potentially released to air effluent streams are discussed first, followed by source terms released to liquid effluent streams.

Unconfined contact with ventilation air is the only prerequisite for an inventory to contribute a gas or aerosol source term to the air effluent stream. Thus, all "passive" inventories stored in open containers, as well as those undergoing cutting, grinding, heating, and other "active" processes, can potentially produce gas or aerosol source terms. The following sections discuss potential source terms under normal, shutdown, and upset conditions.

Under normal operating conditions, all releases of radioactive materials undergo at least two stages of HEPA filtration. Almost all releases are sampled and monitored for total alpha, total beta, and iodine while leaving the facility through the main stack. In addition, the main stack is sampled for radon and thron gases. A minor amount of radioactivity may be released from the decontamination cell; this undergoes sampling for radioactivity. The activities that may generate normal source terms, their locations, and the types of source term that may be added to effluent streams are described below. Only the activities that have taken place in the last year or are expected to take place in the near future are included.

Normal operations can be broken down into storage and handling, sample preparation, and testing and use of instrumentation. Storage and handling operations tend not to produce emissions. Sample preparation is likely to include cutting or grinding of solid samples and possibly handling of small amounts of powder and contaminated etchant. In addition, dissolution of radioactive materials has been performed and can result in the release of gases or vapors. The source terms from testing and use of instrumentation are less well defined but probably small compared to others. All these source terms can be described in terms of four basic physical forms in which radioactive chemicals are found in the 327 Facility: powders or fines, crushable solids, metals, and gases/vapors generated in process.

Powders or fines are typically subjected to the physical processes of pouring, sieving, and resuspension of particulate from loose powders by air flow or wiping. The only operations normally performed on crushable solids (such as fuel pellets) are those that can be categorized as machining, such as cutting and grinding. Releases from the unmachined solids are much lower than for powders. In general, releases from metals are even lower than those from crushable solids.

The releases from normal operating processes can be roughly estimated based on current methods for release calculation (Ayer et al. 1988). Judging by this information, it seems likely that the fraction of the facility inventory that is made airborne within the facility during a year of normal operations is less than the annual release fraction that was assumed in Appendix B calculations for FEMP determination purposes. The Appendix B source term fractions--1.0 for gases and volatiles, $\mathbf{0 . 0 0 1}$ for nonvolatile powders and liquids, and $1 \times 10^{-6}$ for solids and 
Shutdown Conditions

Upset Conditions sealed sources-are therefore upper limits on the estimated annual facility release fraction within the facility. The actual in-facility source term estimates are easily several orders of magnitude lower.

The radionuclide releases from the 327 Facility during normal operations depend on the in-facility source term, the effectiveness of effluent filtration, and the amount of inventory that undergoes normal operations during the year. Airbone releases pass through at least two stages of HEPA filtration before being released. The major contributor to airborne releases has been from radon and thoron gases generated from dissolution of medical isotope sources. Filtration is not effective in mitigating these release.

Radionuclide releases are routed through the main stack. Main stack monitoring is required by NESHAPs.

During shut down, all materials will be in a configuration that can be relied upon not to undergo unexpected changes. All radionuclides and reactive chemicals will be stored in closed containers. No particulate radionuclide releases except for minor resuspension of holdup are anticipated for shutdown conditions. Radon and thoron gases continue to be emitted from the decay of thorium and radium contamination in the cell where medical isotope processing has taken place.

Upset conditions as considered in this document are those that are more than likely to occur. These events may either cause an unusual source term that follows a normal effluent pathway (source-term upset), or a normal source term that follows an unusual pathway (flow-path upset). Both of these types of upset conditions are discussed in this section.

Flow-Path Upsets. Flow-path upsets occur when normal source terms follow unintended paths to be released at effluent exit points. In general, this results in increased release owing to bypassed engineered controls, such as HEPA filters. An Operational Safety Requirement (OSR) on the facility ventilation and off-gas HEPA filters assures that any release of radioactive particles passes through at least one stage of HEPA filtration. Upset conditions (such as a release into the canyon) may not follow a normal flow path through the cell HEPA filters, but would be expected to go through at least one stage of HEPA filters and be vented out the facility stack which has NESHAPs required monitoring.

The decontamination cell inventory, when present, is a small percentage of the current facility inventory (although an exact value is not known). If one of the decontamination cell outlet HEPA filters were to fail, leaving only one stage of HEPA filtration on the decontamination cell exhaust, the upset release would be less than that for the main stack. Monitoring and sampling of the decontamination cell exhaust is required by NESHAPs.

Source-Term Upsets. Source-term upsets occur when an upset creates an unusually large source term, which then follows normal release paths. Upsets that are likely to occur involve only the contents of a single container.

Judging by the airborne source terms given by Ayer et al. (1988) for fires, spills and sprays of powder and liquid, and crushing of solids, the source-term fractions for these types of events are likely to be no more than 10 to 50 times as high as for normal operations. That is, 10 to $\mathbf{5 0}$ times as much material is released during a source-term upset as is released all year from normal operations. (This 


\subsubsection{Liquid Source Terms}

Normal Operations does not hold for gases, which already have an upper limit of 1.0.) Only the inventory in a single container or work station would be affected, and damage to sealed sources would not be a credible upsets. The upper-limit, single-item inventory (and source term) is no more than $10 \%$ of the total facility inventory (and source term) for radionuclides.

The upper-limit, source-term upset would be routed through two stages of HEPA filters and through the main stack for which monitoring is required. An upperlimit, decontamination cell, source-term upset would cause a release even lower than that from the other cells because the lower inventory.

Upon exit from the 327 Facility, control and monitoring responsibility for each of the three liquid waste systems passes from PNL to WHC. Since the streams are under WHC control at the point of discharge to the environment, sampling to demonstrate compliance with regulations is performed by WHC. Although PNL does not have responsibility for compliance sampling of these 300 Area streams, PNL does have the responsibility for maintaining control and accountability for operational discharges from its facility. Therefore, this section identifies the characteristics of the liquid effluent for each pathway, and notes the streams that should be sampled or monitored for characterization purposes. At the present time, PNL is not routinely sampling 327 Facility effluent streams, but samplers are being installed and operational by the end of 1994 .

Source terms to the liquid effluent pathways are those entering the SNS, PS, or RPS systems. The RLWS is sent via casks and piping to other containment outside the facility and is not released to the environment under normal conditions. The casks and double-containment piping are designed such that upset conditions would not cause an environmental release. Thus, only the SNS, PS, and RPS systems are discussed in this section. The following sections describe liquid effluent system releases under normal operating, shutdown, and upset conditions.

Under normal operating conditions, the SNS only receives effluent from the restrooms, water fountains, lunchrooms, and change rooms. No radioactive source terms are normally released through this pathway. The PS, which serves a number of laboratory areas, also does not have a potential for containing radioactive material.

Activities in the 327 Facility are administratively controlled such that the effluent from the RPS is free of radioactive contamination during normal operations.

Because the RPS serves areas of potential contamination, this system may contain radioactive material only under upset operating conditions. Liquid effluent from this system is monitored for gamma radioactivity before the effluent is released to the 300 Area PS.

These facts indicate that the current normal operations do not call for monitoring or sampling of the 327 Facility SNS, PS, or RPS sewer effluent. However, past operations are believed to have caused PS and RPS releases of materials that are now regulated, but then were not. For this reason, samplers are to be installed on the PS system by 1995. 
Shutdown Conditions

Upset Conditions
It is not likely that any liquid effluent source terms would occur during a facility shut down. The activities that can normally cause releases do not occur during shut down. Maintenance activities do not employ radionuclides.

As for upsets releasing airborne materials, the liquid effluent upsets that are likely to occur are the result of one failure of a system or control, or one human error. Upsets can be categorized as spills and contamination of process water.

Because of the separation between the SNS and PS and the facility radioactive source terms, normal radioactive source terms cannot escape by using the SNS or PS as an abnormal flow path. There are no flow-path upsets (e.g., failures of the RPS diverter monitor or diversion valve) that would be adequate to cause a release of radioactivity to the PS from the RPS, since a radioactive source term is not normally present. However, since the RPS serves areas of potential radioactive contamination, a source-term upset release of radioactive material could occur from spills or contamination of process water entering these systems. Such a release to the RPS could only be passed to the PS if the radionuclide concentration were below the diversion set-point of $5 \times 10^{-5} \mu \mathrm{Ci} / \mathrm{ml}$ of ${ }^{137} \mathrm{Cs}$ or its gamma equivalent. If the radionuclides in the spill were alpha or beta emitters, or gamma emitters with concentrations that are higher than the value cited above for ${ }^{137} \mathrm{Cs}$, the stream will pass through to the PS without diversion as a result of the source-term upset.

Radioactive contamination of RPS water could occur by spills, leaks of process inventories into cooling water, or carryover of inventory in off-gas streams drawn off by and condensed in the vacuum system.

Although administrative and engineered controls are in place to reduce the potential for upset conditions that could lead to releases of unwanted materials to the PS and RPS systems, the potential still exists. Liquid effluent sampling capability is to be installed on the 327. Facility PS system by 1995.

\subsection{Summary and Conclusions}

Under normal operations, radioactive airborne source terms pass through two stages of HEPA filtration and are sampled and/or monitored prior to their release from the main stack or the decontamination cell stub stack. Radioactive aerosol generated under upset conditions that are likely to occur are also carried through the main stack or stub stack, though it may have undergone only one stage of HEPA filtration. The upper-limit radioactive releases from the main stack are high enough under upset conditions to justify monitoring and sampling.

The only liquid effluent system that is released to the 300 Area PS system and has a potential for containing radionuclides under upset (but not normal) conditions is the RPS. This system includes monitoring for gamma radioactivity before the effluent is released to the 300 Area PS. Sampling capability is to be added to the PS and RPS by 1995.

\subsection{References}

40 CFR 61. 1990. Subpart H--National Emission Standards for Emissions of Radionuclides Other than Radon from Department of Energy Facilities. 7-1-90 Edition. U.S. Environmental Protection Agency, Washington, D.C. 
Ayer, J. E., A. T. Clark, P. Loysen, M. Y. Ballinger, J. Mishima, P. C. Owczarski, W. S. Gregory, and B. D. Nichols. 1988. Nuclear Fuel Facility Accident Analysis Handbook. NUREG-1320, U.S. Nuclear Regulatory Commission, Washington, D.C.

PNL. 1987. Safety Analysis Report for 327 Building. HEDL-TC-1009, Westinghouse Hanford Company, Richland, Washington. 


\subsection{Effluent Point-of-Discharge Description}

The term "point of discharge" as used in this chapter refers to the point at which the effluent leaves PNL control. For airborne emissions, the discharge point coincides with the point of effluent entry into the uncontrolled environment. Thus, "discharges" of airborne emissions must comply with DOE, EPA, and WDOH emission control and monitoring requirements. Liquid effluents originating in the 327 Facility, on the other hand, remain in a controlled system at the point of discharge. At this point, the responsibility for the effluent stream, including its ultimate disposition, passes from PNL to the site operations contractor, WHC. WHC has the responsibility for monitoring and controlling environmental discharges of liquid effluents.

WHC has established a separate FEMP to cover 300 Area liquid effluent discharge monitoring and control systems. Although PNL does not control the discharge of liquid effluent from 300 Area facilities, PNL does have responsibility for characterizing effluents originating in its facilities and for exercising appropriate control over these effluent sources.

This section provides information on the final point of discharge of liquid and airborne effluents originating in the 327 Facility.

\subsection{Airborne Emission Exhaust Points}

\subsubsection{Numbered Exhaust Points}

Issued: $11 / 94$

Supersedes: $11 / 91$
Airborne emissions from the 327 Facility are primarily via stacks and vents, although as discussed in Section 4.0, in some upset situations minor outleakage is possible via doorways and facility leaks.

Numbered exhaust points include all point-source discharge locations except for sanitary and process sewer vents. These exhaust points are listed in Table 5.1, and their locations are shown in Figure 5.1 on a plan view of the 327 Facility. Each exhaust point is identified by a unique "EP" number in the table and on the figure. The EP numbers also correspond to exhaust points identified on the 327 Facility exhaust flow diagrams in Section 4.0. Thus, with the information provided in this plan, it is possible to start with an identified exhaust point on the facility, and determine the origins within the facility of emissions at this point.

Emission sampling and monitoring is performed at the main facility stack, shown as exhaust sample point ESP-327-01-S in Figure 5.1 and at the decontamination cell exhaust shown as ESP-327-02-D. These monitoring locations are also shown on the facility exhaust flow diagram in Section 4.0. Detailed descriptions of the sampling/monitoring systems are given in Section 7.0.

Where the exhaust system is powered by fans or blowers, nominal exhaust flow rates are given in Table 5.1. Before 1991, the exhaust flow rate at these points was measured annually using the Associated Air Balance Council (AABC) national standards (AABC 1982). Since 1991, the exhaust gas velocities and volumetric flow rates have been measured using the EPA Method 2 (40 CFR 60) velocity traverse procedure at the sampling location. The use of quarterly measurements was implemented in 1994. 
Table 5.1. 327 Facility Ventilation Exhaust Points

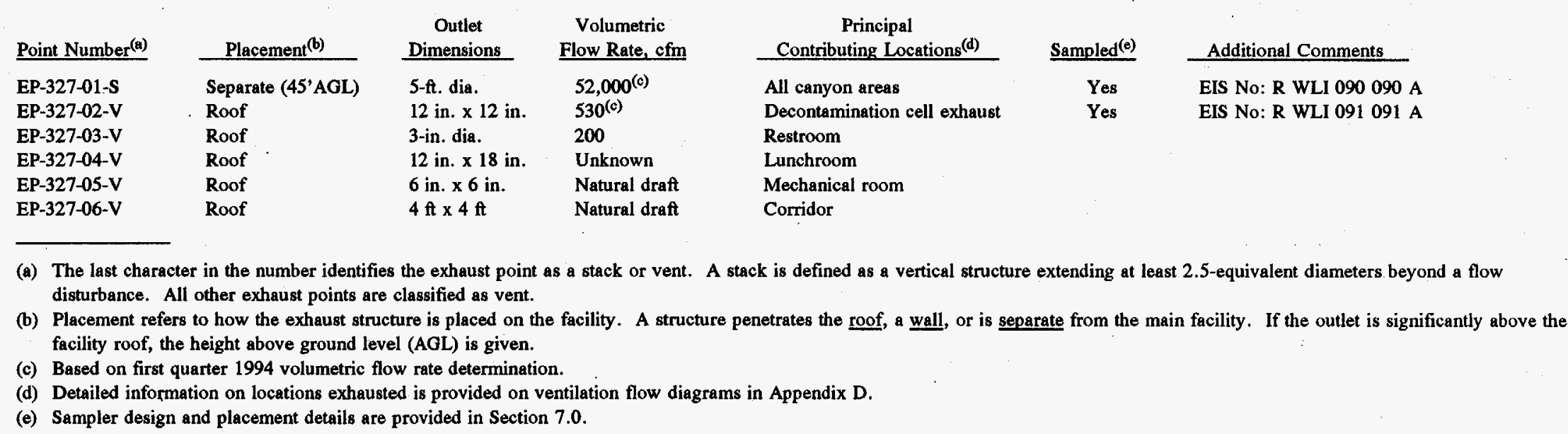

Separate (45'AGL)

Roof

Roof

Roof

Roof

Roof

Outlet

\section{Dimensions}

5-ft. dia.

12 in. $\times 12$ in.

3-in. dia.

12 in. $\times 18$ in.

6 in. $x 6$ in.

$4 \mathrm{ft} \times 4 \mathrm{ft}$

Volumetric

Flow Rate, cfm

$52,000^{(c)}$

$530^{(\mathrm{c})}$

200

Unknown

Natural draft

Natural draft

Principal

\begin{tabular}{l} 
Contributing Locations $(\mathrm{d})$ \\
\hline All canyon areas \\
Decontamination cell exhaust \\
Restroom \\
Lunchroom \\
Mechanical room \\
Corridor
\end{tabular}

\section{Sampled (e) Additional Comments}

Yes

Yes

EIS No: R WLI $090090 \mathrm{~A}$

EIS No: R WLI $091091 \mathrm{~A}$

(a) The last character in the number identifies the exhaust point as a stack or vent. A stack is defined as a vertical structure extending at least 2.5 -equivalent diameters beyond a flow disturbance. All other exhaust points are classified as vent.

(b) Placement refers to how the exhaust structure is placed on the facility. A structure penetrates the roof, a wall, or is separate from the main facility. If the outlet is significantly above the facility roof, the height above ground level (AGL) is given.

(c) Based on first quarter 1994 volumetric flow rate determination.

(d) Detailed information on locations exhauted is provided on ventilution flow digrams in Appendix D.

(e) Sampler design and placement details are provided in Section 7.0. 

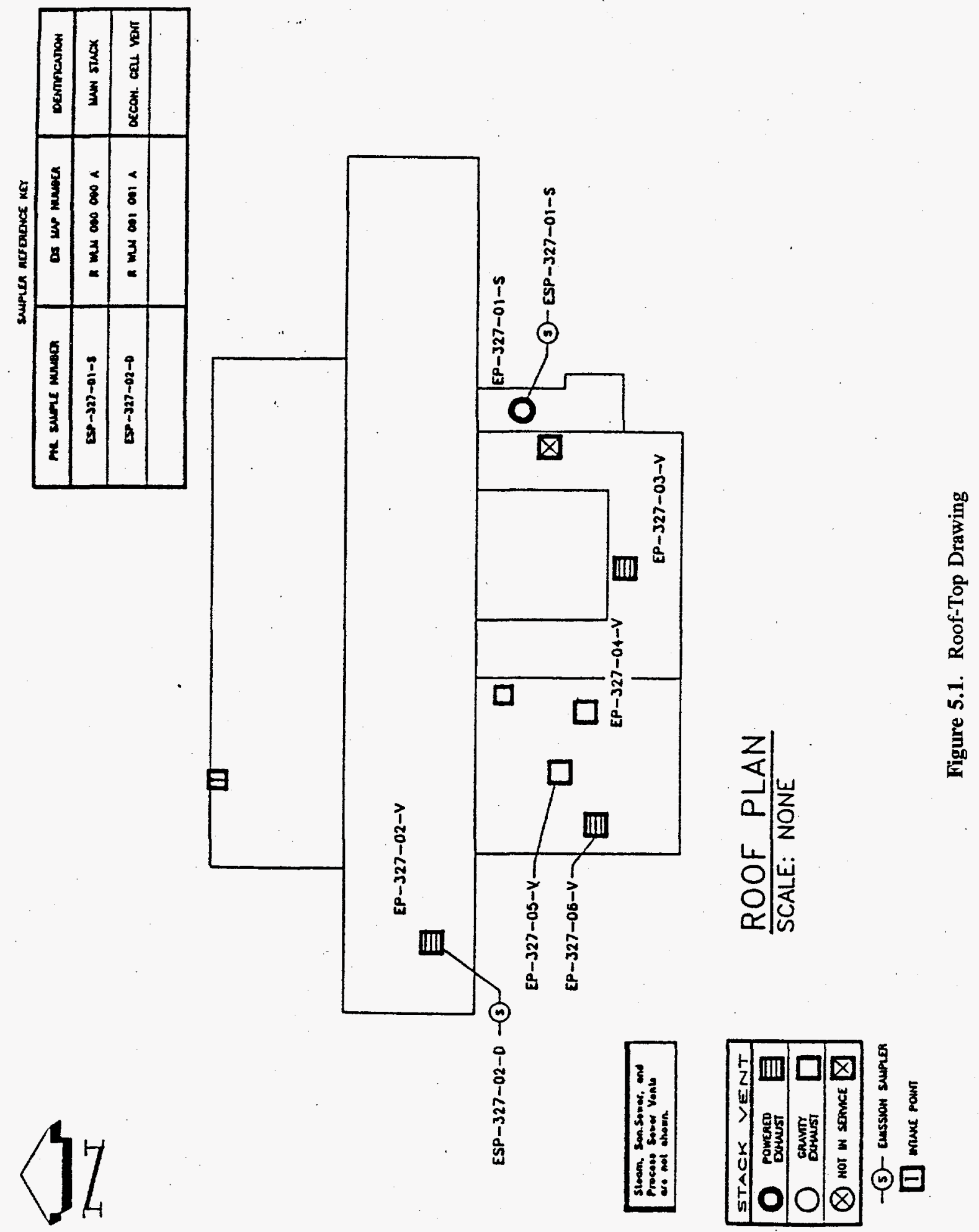
Annual stack volumetric flow rate determinations show the stack to have a relatively constant flow rate. Results of annual volumetric flow rate measurements for the 327 main exhaust stack and decontamination cell vent since 1987 when PNL first occupied the facility are shown in Tables 5.2 and Table 5.3.

Table 5.2. Volumetric Flow Rate Measurements - 327 Main Exhaust

\begin{tabular}{lll} 
Year & & Volumetric Flow Rate, $\mathrm{cfm}^{(\mathrm{a})}$ \\
\cline { 1 - 1 } 1987 & & 46,000 \\
1988 & & 44,000 \\
1989 & & 53,000 \\
1990 & & 49,000 \\
1991 & & $53,000^{(\mathrm{b})}(3 / 28 / 91)$ \\
1992 & & $47,000^{(\mathrm{b})}(9 / 24 / 92)$ \\
1992 & & $44,000^{(\mathrm{b})}$ \\
1993 & & $46,000^{\text {(b) }}(6 / 18 / 93)$ \\
1993 & & $51,000^{(\mathrm{b})}(10 / 28 / 93)$
\end{tabular}

(a) Rounded to two significant figures.

(b) Measured using EPA Method 2 (40 CFR 60).

Table 5.3. Volumetric Flow Rate Measurements - 327 Facility Decontamination Cell Exhaust

\begin{tabular}{lll} 
Year & & Volumetric Flow Rate, $\mathrm{cfm}^{(\mathrm{a})}$ \\
\cline { 1 - 1 } 1987 & & 900 \\
1988 & & 630 \\
1989 & & 680 \\
1990 & & 540 \\
1991 & & $520^{\text {(b) }}(4 / 8 / 91)$ \\
1992 & & $530^{\text {(b) }}(4 / 28 / 92)$ \\
1992 & & $740^{\text {(b) }}(11 / 17 / 92)$ \\
1993 & & $630^{\text {(b) }}(6 / 18 / 93)$ \\
1993 & & $580^{(b)}(11 / 22 / 93)$
\end{tabular}

(a) Rounded to two significant figures.

(b) Measured using EPA Method 2 (40 CFR 60). 


\subsubsection{Other Potential Exhaust Points}

Sanitary and process sewer vents constitute a pathway for exhaust to the environment; however, the systems do not contain radioactive contamination, and flow rates are cyclicle as liquids pass through the piping.

Ventilation air supply units have louvers but do not have backdraft dampers. Several access doors to the facility provide immediate access to the canyon area. With the exception of the truck lock, these doors are for emergency escape. Each of the normally used access points is equipped with a contamination monitor. The truck lock area is equipped with a CAM.

\subsection{Liquid Effluent Discharge Points}

Liquids effluents are discharged from the 327 Facility via the SNS system, the PS system, and the RLWS (see Section 2.2). These systems come under WHC control either just prior to or just after their exit from the facility. Table 5.4 summarizes the characteristics of these systems and Figure 2.5 shows the general layout of liquid effluent systems in the 300 Area.

Within the 327 Facility, the PS line branches into two contributing systems: the PS and the RPS. The RPS line serves processes and locations that are normally not contaminated, but would have a potential for contamination in the event of a failure of an engineered barrier or administrative procedure. Under normal operating conditions, the RPS connects to the PS. As part of their liquid effluent control responsibility, WHC maintains a gamma-radiation monitor on the RPS line. If this monitor detects radiation in the RPS above its alarm point, it actuates a control valve that reroutes the RPS to the RLWS. The diverter station is operated and maintained by WHC.

These systems are currently not being sampled by PNL, although efforts are underway to install samplers in each of the effluent lines exiting the facility (see Section 14.0).

Rainwater from the facility roof and runoff from the loading dock drain to the soil at various locations around the facility. There is no radioactive or chemical contamination present on external facility surfaces.

\subsection{Reference}

Associated Air Balance Council. 1982. National Standards for Total System Balance. AABC 1133 15th N.W., Washington D.C.

Table 5.4. Liquid Effluent Discharge Lines

\begin{tabular}{|c|c|c|}
\hline Liquid Discharge System & Pipe Size & Facility Exit Point \\
\hline Sanitary Sewer & & East Service Tunnel \\
\hline Process Sew & 10-cm (4-in.) dia. & East Service Tunnel \\
\hline Process Sewer-2 & 20-cm (8-in.) dia. & \\
\hline Rad. Liq. Waste System & 10-cm (4-in.) dia. & North side of facility \\
\hline
\end{tabular}





\subsection{Effluent Monitoring/Sampling System Requirements and Criteria}

This section discusses design criteria for the 327 Facility airborne emissions measurement program. Criteria are established to ensure that effluent measurements are performed according to applicable regulations and guidance and are appropriate for existing facility operations. Effluent streams from the 327 Facility are sent to one of the 300 Area liquid effluent systems (operated by WHC for DOE-RL). Thus, the 327 Facility does not have a liquid discharge to the environment. However, a sampling/monitoring program is in place for the facility with sampling estimated to begin before 1995 .

In this section, the terms "sampling" and "monitoring" are used to distinguish between two types of airborne emissions measurement processes:

"Sampling" refers to the collection of a representative portion of the emission over a period of time, with subsequent analysis for constituents of interest.

"Sampling" is an "after-the-fact" measurement.

"Monitoring", on the other hand, is the measurement of radionuclide emission rates by means of a detector located in the sample stream. "Monitoring" is a "real-time" measurement.

Airborne emission sampling is performed to demonstrate compliance with emission standards, to identify emission trends, and to provide evidence regarding the effectiveness of emission control systems (procedures and equipment). Emission monitoring is performed as a means to provide timely indication of a significant change in emission rate.

Section 7.0 describes design and operation of the airborne emission sampling/ monitoring system at the 327 Facility with specific reference to the criteria discussed in this section.

\subsection{Basis for Design Criteria}

Effluent sampling and monitoring system design and operation criteria are based on the following regulations and guidance:

40 CFR 60. Environmental Protection Agency, "Regulations on Standards of Performance for New Stationary Sources, Appendix A: Reference Methods." U.S. Code of Federal Regulations.

40 CFR 61. 1990. "National Emission Standards for Hazardous Air Pollutants." U.S. Code of Federal Regulations.

American National Standards Institute (ANSI). 1980. "Guide to Sampling Airborne Radioactive Materials in Nuclear Facilities." ANSI N13.1 - 1980.

American National Standards Institute (ANSI). 1980. "Specifications and Performance of Onsite Instrumentation for Continuously Monitoring Radioactivity in Effluents." ANSI N42.18 1980b.

U.S. Department of Energy. 1990. "Radiation Protection of the Public and the Environment." DOE 5400.5. 
U.S. Department of Energy. 1987. "General Design Criteria." DOE 6430.1A.

U.S. Department of Energy. 1991. Environmental Regulatory Guide for Radiological Effluent Monitoring and Environmental Surveillance. DOE/EH-0173T. (Regulatory Guide)

Additional requirements for sampling/monitoring at the 327 Facility are prescribed in PNL operational and programmatic documents. These are:

Gruber, W. J. 1987. Postirradiation Testing Laboratory (327 Building) Safety Analysis Report. HEDL-TC-1009, Hanford Engineering Development Laboratory, Richland, Washington.

Washington Department of Health. 1994. Radiation Protection - Air Emissions. Chapter 246-247 Washington Administrative Code.

\subsection{Criteria for Airborne Radionuclide Emission Sampling}

Airborne radionuclide emission points at PNL are classified as either "major" or "minor". These two categories are defined as follows.

Major emission points are those where radionuclide emissions could cause an offsite emission dose of $0.1 \mathrm{mrem}$ if emission controls were not applied. Sampling of major emission points is performed according to requirements in 40 CFR 61 Subpart $H$.

NOTE: The annual offsite emission dose (OED) is the maximum committed effective dose equivalent that could be expected to be received by an offsite individual from facility airborne radionuclide emissions if the facility was operated without any HEPA filtration or other emission controls. The method for calculating the OED, as described in PNL-MA-8, consists of identifying the radionuclide inventory potentially available for release, multiplying this by a fractional release value, and multiplying this product times an emission dose factor calculated by the EPA Clean Air Act compliance code CAP-88.

PNL 10061 provides additional discussion of this assessment method.

Minor emission points are those that potentially could release radionuclides, but not at the levels of a "major" point.

\subsubsection{Sampling System Performance}

Sampling at each major emission point shall be capable of detecting an annual radionuclide release quantity resulting in an OED of $0.1 \mathrm{mrem}$.

All radionuclides anticipated to contribute greater than $10 \%$ of the emission dose from the sampled emission point shall be accounted for, either by direct analysis or by inference from an indicator measurement.

Biases in emission measurements, arising from the sample collection and analysis process, shall be minimized through the judicious application of design and operation practices according to American National Standards Institute (ANSI) N13.1 and DOE/EH-0173T. 


\subsubsection{Sampling System Design Criteria}

Samplers shall be located according to criteria in EPA Method 1 in Appendix A of 40 CFR 60 . Method 1 states that

"Sampling or velocity measurement are to be performed at a site located at least eight stack or duct diameters downstream and two diameters upstream from any flow disturbance such as a bend, expansion, or contraction in the stack, or from a visible flame." However, the method also states that, "if necessary, an alternative location may be selected, at a position at least two stack or duct diameters downstream and 0.5 diameters upstream from any flow disturbance".

Representative samples shall be withdrawn on a continuous basis at the sampling site following the guidance in ANSI N13.1, Appendix A, Section A3.2, which recommends a minimum of six extraction points for the 327 Facility stack (ESP-327-01-S) and four extraction points for the decontamination cell exhaust (ESP-327-02-D). Furthermore, ANSI N13.1 recommends that each withdrawal point within a cylindrical stack be centered in an annular area of size equal to the cross sectional area divided by the number of probes. Withdrawal points may be on a single traverse or spaced to obtain samples from the total cross section. Additional design criteria for particulate and gaseous radionuclides are specified by ANSI N13.1 and DOE/EH-0173T.

\subsubsection{Sampling System Operation}

Sampling system operating criteria are based on regulations and guidance documents listed in 6.1.

Sampling shall be performed to quantify emissions over a calendar year period. Sample collection frequency shall be based on the need for unbiased samples while maximizing sensitivity and minimizing analytical costs. The period of sample collection thus should be as long as possible considering the half-life of the radionuclide, the capacity of the collection media, and the need for timely return of sampling data.

Since quarterly reports of facility emission trends are required by DOE (per Hanford RadCon Manual), the maximum sampling period should be three months. Where sample collection media with limited capacity are used (e.g., silica gel for water vapor collection, glass-fiber filter for particulate collection) sampling periods need to be reduced accordingly. Also, for sampling of short half-life radionuclides, the duration of the collection period should not exceed three halflives; and a correction for decay of the nuclide should be made.

Laboratory analysis of samples shall be according to procedures required by Appendix B, Method 114 "Test Methods for Measuring Radionuclide Emissions from Stationary Sources" in 40 CFR 61. Analyses should be conducted by radioanalytical laboratories according to prescribed statements of work. Work statements specify analytical performance requirements including minimum detectable activity (MDA), turnaround time, reporting requirements, quality control (QC) requirements, and sample handling.

Sampling program criteria in Section 6.2.1 specify an emission detection level of 0.01-mrem OED. The analytical MDA required to meet this criterion depends on 
a combination of factors including sample size, stack flow rate, collection period, radionuclide half-life, and radionuclide emission dose factor.

Historically, laboratory analysis of particulate emission samples consisted of total activity (total alpha, total beta) measurements. Total activity measurements were performed because:

- Emissions have historically been very low

- Potentially significant constituents of the emission stream were known, and

- The gross activity measurement is nondestructive; radionuclide-specific measurement could be performed on the sample if gross activity measurements show a potentially significant release quantity.

When gross activity measurements were used for assessing offsite dose, dose factors for the most restrictive radionuclide potentially contributing $10 \%$ or more to the annual emission dose were applied.

Since 1993, airborne particulate samples must be analyzed for several specific radionuclides in addition to the gross activity measurements. These specific analyses should include those radionuclides potentially contributing $10 \%$ of the offsite dose from the facility.

Exhaust stream flow rates at sampling locations shall be measured using EPA Method 2 (40 CFR 60). Flow rate measurements should be performed on a periodic basis, as well as following modifications to the exhaust system that could be expected to cause the average exhaust rate to differ by $+/-10 \%$ from the previously measured rate. Normally, stack flow rates should be measured on a quarterly frequency. However, if instantaneous flow rate at the sample location is expected to deviate from the mean flow rate by a factor of two more than $10 \%$ of the time, and the OED exceeds or is expected to exceed $1 \mathrm{mrem}$, continuous stack exhaust flow rate monitoring and totalizing should be provided (DOE/EH-0173T).

Air emission samplers should be designed to maximize the sensitivity of the sample, considering the capacity of the collection media, radioactive decay, and sample analysis costs.

Isokinetic sampling is required where particulate emissions are expected.

NOTE: Emissions from the 327 stack are filtered using HEPA filters prior to discharge. Unless failure of a HEPA filter system occurs (an unlikely event), particle emissions are expected to be relatively small. Based on criteria in ANSI N13.1, isokinetic sampling for systems emitting particles less than $5-\mu \mathrm{m}$ aerodynamic diameter is not necessary. The DOE Regulatory Guide recommends isokinetic sampling when particles greater than $0.5-\mu \mathrm{m}$ aerodynamic median diameter is exceeded.

Under most operating conditions, isokinetic sampling can be adequately accomplished by operating the sampler so that 1) sample probes are aligned axially with the stack and point into the direction of stack flow, and 2) sample nozzle inlet 
velocity is maintained within a factor of two of the mean stack exhaust velocity at the sample location.

NOTE: From Table C1 in ANSI N13.1, a sampler operating at an inlet velocity of within a factor of two of the stack velocity will have a particle interception bias of $14 \%$ for a $4-\mu \mathrm{m}$ aerodynamic equivalent diameter (AED) particulate emission.

At the "major" emission points, The sampler is operated continuously except during planned sampler maintenance or testing outages. When continuous sampling is required, the loss of sampling capability is limited to $24 \mathrm{~h} /$ month. If this limit is exceeded, special interim sampling is provided or pertinent facility operations are shut down.

\subsection{Criteria for Emission Monitoring}

\subsubsection{General}

\subsubsection{Monitor Performance}

\subsubsection{Monitor Design}

\subsubsection{Monitor Operation}

Continuous emission monitoring is required for any emission system where

- a potential of greater than once per year exists for exceeding $20 \%$ of the OED standard of $10 \mathrm{mrem} / \mathrm{yr}$ (credit may be taken for emission control equipment such as HEPA filters) per DOE/EH-0173T, or

- continuous emission monitoring is specified by a SAR or operational safety requirement (OSR).

The main stack of the 327 Facility (EP-327-01-S) meets the criteria in the second bullet. The 327 Facility SAR requires continuous alpha and beta particulate and radioiodine monitoring.

The purpose of continuous emission monitoring is to detect a significant increase in stack emission rate. Rapid detection of such an increase may assist operational response actions. The 327 Facility stack monitoring system is not used to activate engineered control systems, is not relied upon as a primary means for detecting an abnormal operating situation, and is not used to continuously monitor radionuclide release rates during normal facility operations.

The emission monitor should be able to detect a sudden release that could (assuming 95th percentile atmospheric dispersion under 2-h meteorological conditions) result in an OED of 2 mrem (i.e., $20 \%$ of the emission standard). The monitoring program should effectively provide notification to responsible personnel within $4 \mathrm{~h}$ of onset of such a release.

General criteria for design of monitoring systems are provided in DOE/EH-0173T.

Monitors are operated continuously, except

- when the monitored exhaust system is not operating, if approved by the Facility Manager and EC

- during planned maintenance or testing of the monitoring system if scheduled through the Facility Manager.

During periods when the exhaust system is operating and sampling is required, loss of monitoring capability is not to exceed $4 \mathrm{~h}$ at a time. If monitor outage 
exceeds this time, EC is required to specify requirements for interim sampling of emissions or shut down of pertinent operations.

Continuous stack monitors must provide easily discernible alarms to responsible personnel in continuously or frequently occupied areas. A frequently occupied area is one that is occupied at least once every 4 clock hours.

Flow rates through monitors should, in combination with other operating parameters, be sufficient to enable the monitor to detect an emission meeting the above dose criteria. 


\subsection{Characterization of Current Effluent Monitoring Systems}

Airborne radionuclide emission sampling and monitoring is performed by PNL at the 327 Facility. As described in Chapter 5.0, liquid effluents are discharged via a central liquid waste treatment facility currently operated for the Department of Energy by the Westinghouse Hanford Company.

Airborne radionuclides are potentially emitted from two facility exhaust points. These are the main facility stack (EP-327-01-S) and the decontamination cell exhaust vent (EP-327-02-V).

The main facility stack (EP-327-01-S) is the primary facility exhaust point at a flow rate of just under 50,000 cfm. [Averaged over 1991-1993 (see Chapter 5.0).] The stack is located on the ground on the southeast end of the canyon. Ventilation exhaust from hot cells, maintenance shops, and canyon areas is discharged via the main stack.

The decontamination cell vent (EP-327-02-V), averaging just above $500 \mathrm{cfm}$, is a small vent located on the southwest end of the canyon roof. The decontamination cell exhaust serves the facility waste compactor and the cask loadout station in addition to the decontamination cell.

Facility ventilation air comprises the major portion of the flow at both of the above emission points; thus, stack gas specific gravity is that of air, and humidity and temperature are in the range normally encountered in occupied facilities.

Continuous sampling for radioactive particulates is provided at both of the emission points. In addition, sampling for radon and thoron gases and continuous monitoring of particulate radionuclide and iodine-131 emissions are performed at the main stack. Table 7.1 summarizes emission sampling/monitoring for the 327 Facility.

Table 7.1. Airborne Emission Measurements - 327 Facility

\begin{tabular}{|c|c|c|}
\hline \multirow[b]{2}{*}{ Continuous Sampling } & $\begin{array}{l}\text { Main Stack } \\
\text { EP-327-01-S }\end{array}$ & $\begin{array}{c}\text { Decontamination C } \\
\text { EP-327-02-V }\end{array}$ \\
\hline & & \multirow[b]{2}{*}{$\begin{array}{l}\text { ESP-327-02-D } \\
\text { (Section 7.1.3) }\end{array}$} \\
\hline Particulate Radioactivity & $\begin{array}{l}\text { ESP-327-01-S } \\
\text { (Section 7.1.1) }\end{array}$ & \\
\hline Radon Gases & $\begin{array}{l}\text { ESP-327-01-T } \\
\text { (Section 7.1.2) }\end{array}$ & Not Performed \\
\hline \multicolumn{3}{|l|}{ Continuous Monitoring } \\
\hline Particulate Alpha & $\begin{array}{c}\text { ESP-32701-T } \\
\text { (Section 7.1.4) }\end{array}$ & Not Performed \\
\hline Particulate Beta & $\begin{array}{l}\text { ESP-327-01-T } \\
\text { (Section 7.1.4) }\end{array}$ & Not Performed \\
\hline Iodine-131 & $\begin{array}{l}\text { ESP-327-01-T } \\
\text { (Section 7.1.4) }\end{array}$ & Not Performed \\
\hline
\end{tabular}


Projected radionuclide emissions from the facility, assuming that no emission controls are in place (i.e., no HEPA filtration), are described in Chapter 4.

Using these emissions, radionuclides that may contribute $10 \%$ or more to the offsite dose from 327 Facility emissions are ${ }^{220} \mathrm{Rn},{ }^{137} \mathrm{Cs}$, and ${ }^{238} \mathrm{Pu}$. These radionuclides are included in the continuous emission sampling program.

NOTE: Emission control systems (HEPA filters) are employed in the exhaust stream and actual releases are low. Chapter 8.0 presents measured radionuclide emissions from past operations.

Continuous monitoring of stack emissions is required by the 327 Facility Safety Analysis Report (Gruber 1987) based on the consequences of potential accidents. Currently, airborne emission monitoring is required for airborne particulate radionuclides (alpha and beta radioactivity) and iodine-131. [There currently is no iodine-131 in the facility (see Chapter 4), and discontinuation of iodine-131 monitoring is expected in the near future.]

\subsection{Sampling/Monitoring System Description}

Two independent airborne emission sampling systems are installed in the main facility stack (EP-327-01-S). An ANSI N13.1 compliant isokinetic sampling system (ESP-327-01-S) is used for particulate emission sampling and a separate system (ESP-327-01-T) is used for radon gas sampling and continuous particulate emission monitoring (Figure 7.1).

\subsubsection{Main Stack Particulate Emission Sampling System (ESP-327-01-S)}

A NESHAP compliant airborne particulate radionuclide sampling system (ESP-327-01-S) was installed on the main facility stack in late 1991. The system complies with design requirements in Chapter 6.0.

The sampling system incorporates a six-nozzle isokinetic probe assembly (Figure 7.2) positioned in the stack 5.7 equivalent diameters downstream and 1.4 equivalent diameters upstream of any flow redirection (Figure 7.3). The probe assembly is oriented on a northeast-southwest traverse, and probe nozzles are located at the centers of equal annular areas according to requirements in ANSI N13.1 (1980).

A sample transport line extends from the probe assembly to the base of the stack (Figure 7.3) where a sample collection filter is located (Figure 7.4). The transport line is stainless steel tubing and is heat traced, thermally insulated, and electrically grounded.

Samples of stack airborne particulate emissions are drawn through the probe nozzle assembly using the facility vacuum system. Sample flow is controlled by means of a needle valve mounted downstream from the sample collection filter and flow is measured by a rotameter mounted just upstream from the needle valve (Figure 7.4). Rotameter readings are corrected for system pressure. The needle valve is adjusted so that the average velocity of air entering the sample system through the sample probe assembly is equal to the average velocity of the stack gas at the sampling location. Stack velocities are measured using EPA Method 2 (40 CFR 60) on a quarterly frequency. 


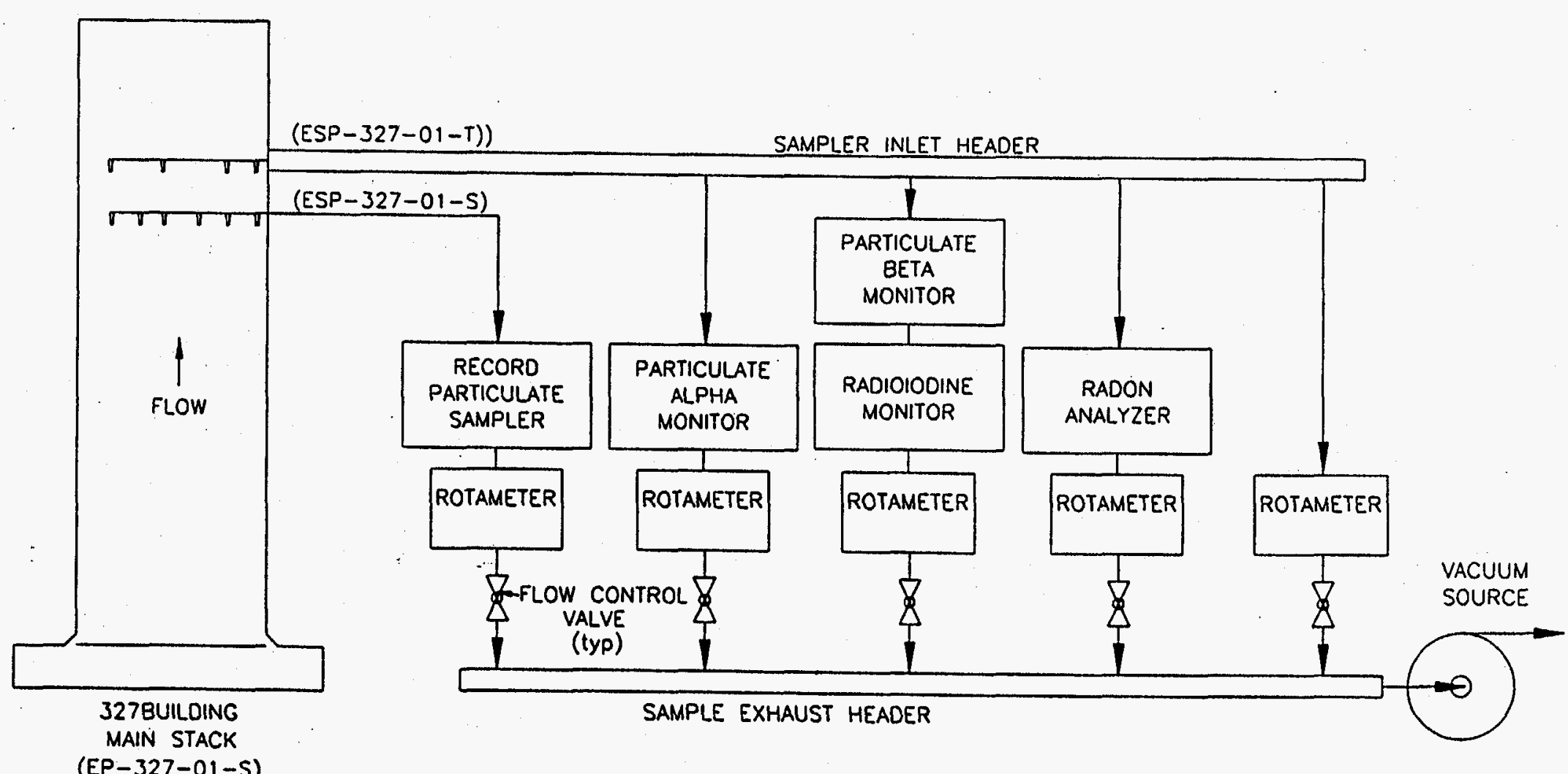

Figure 7.1. 327 Facility Sampling Systems 


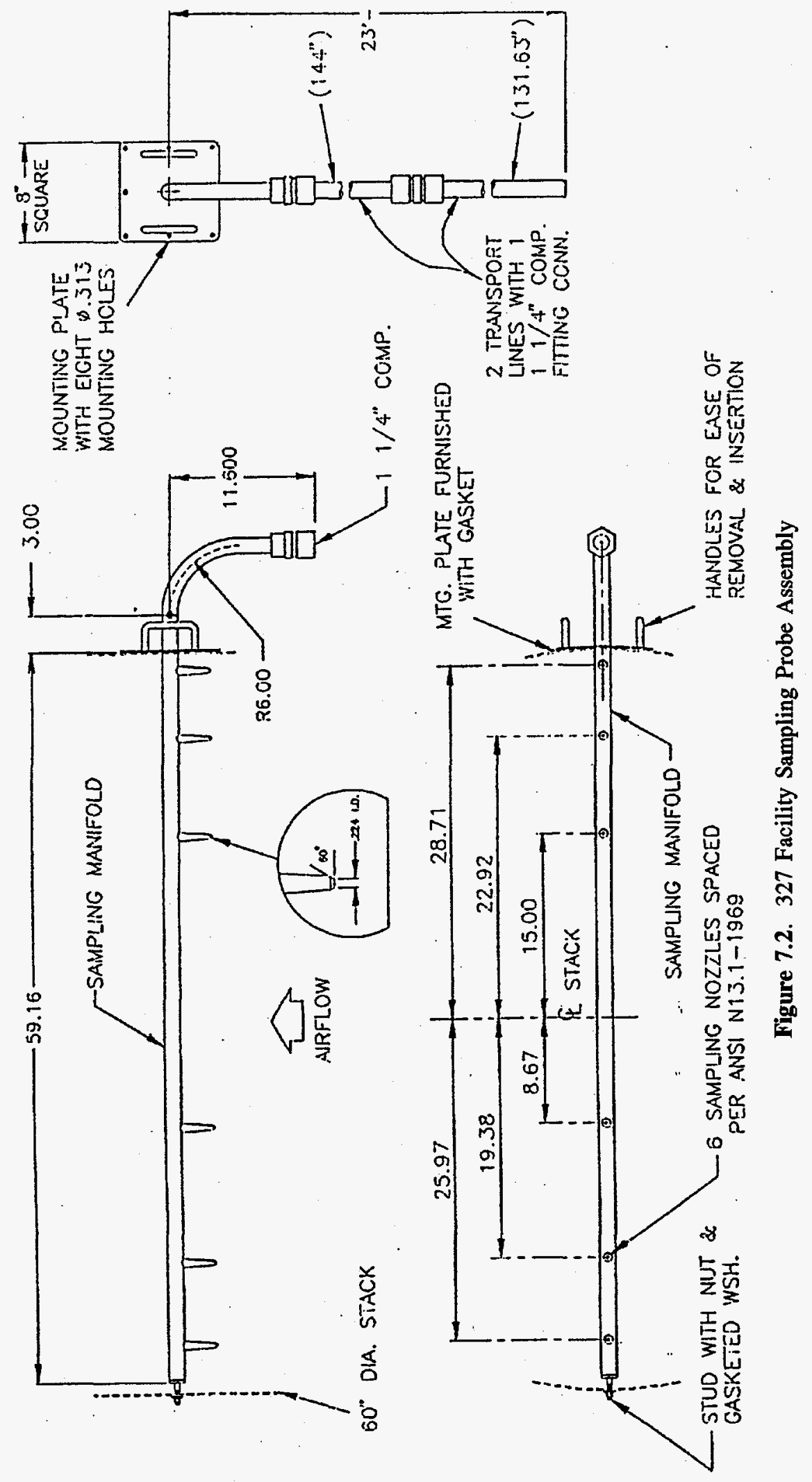




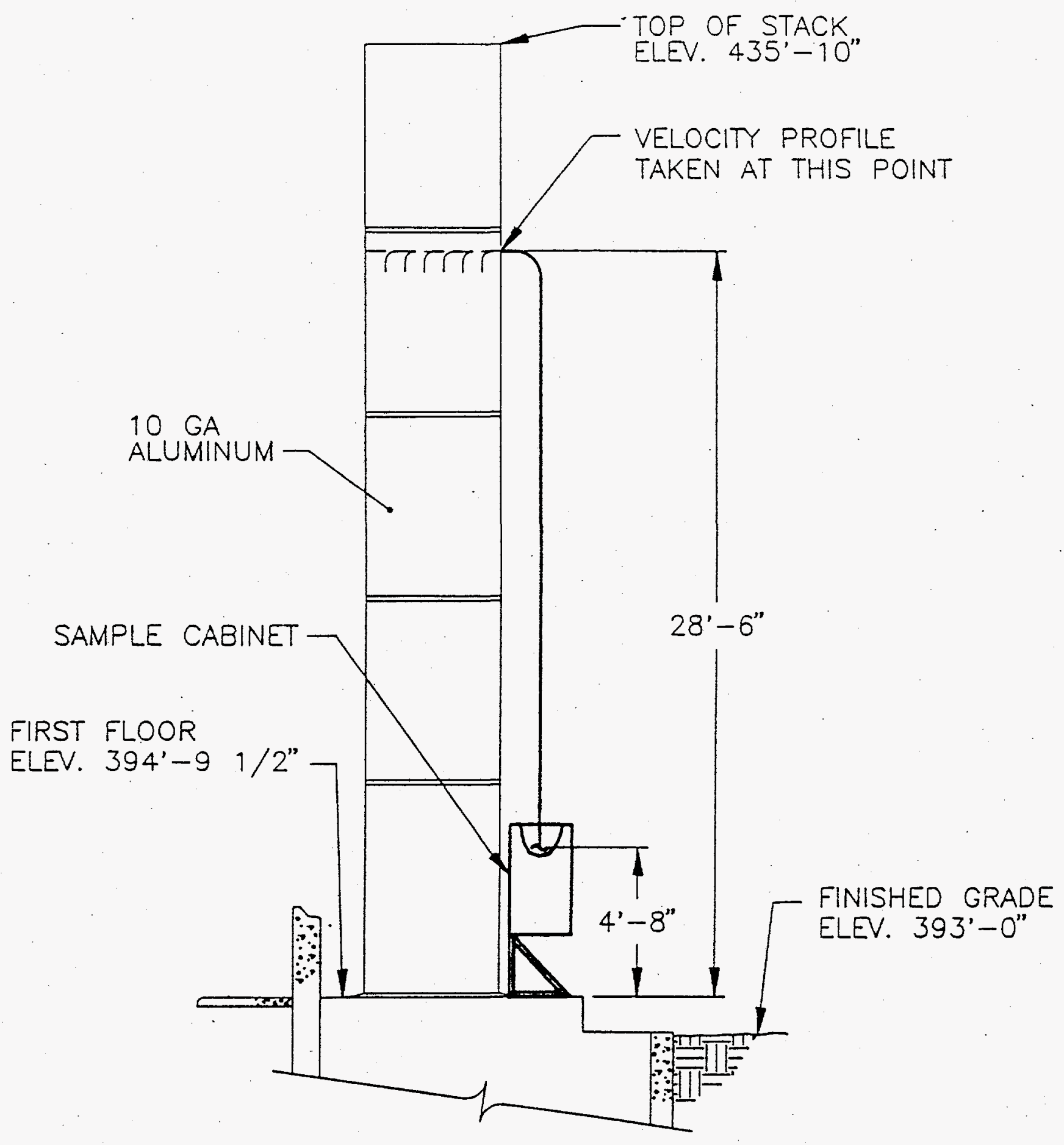

Figure 7.3. Sampling System on 327 Stack 


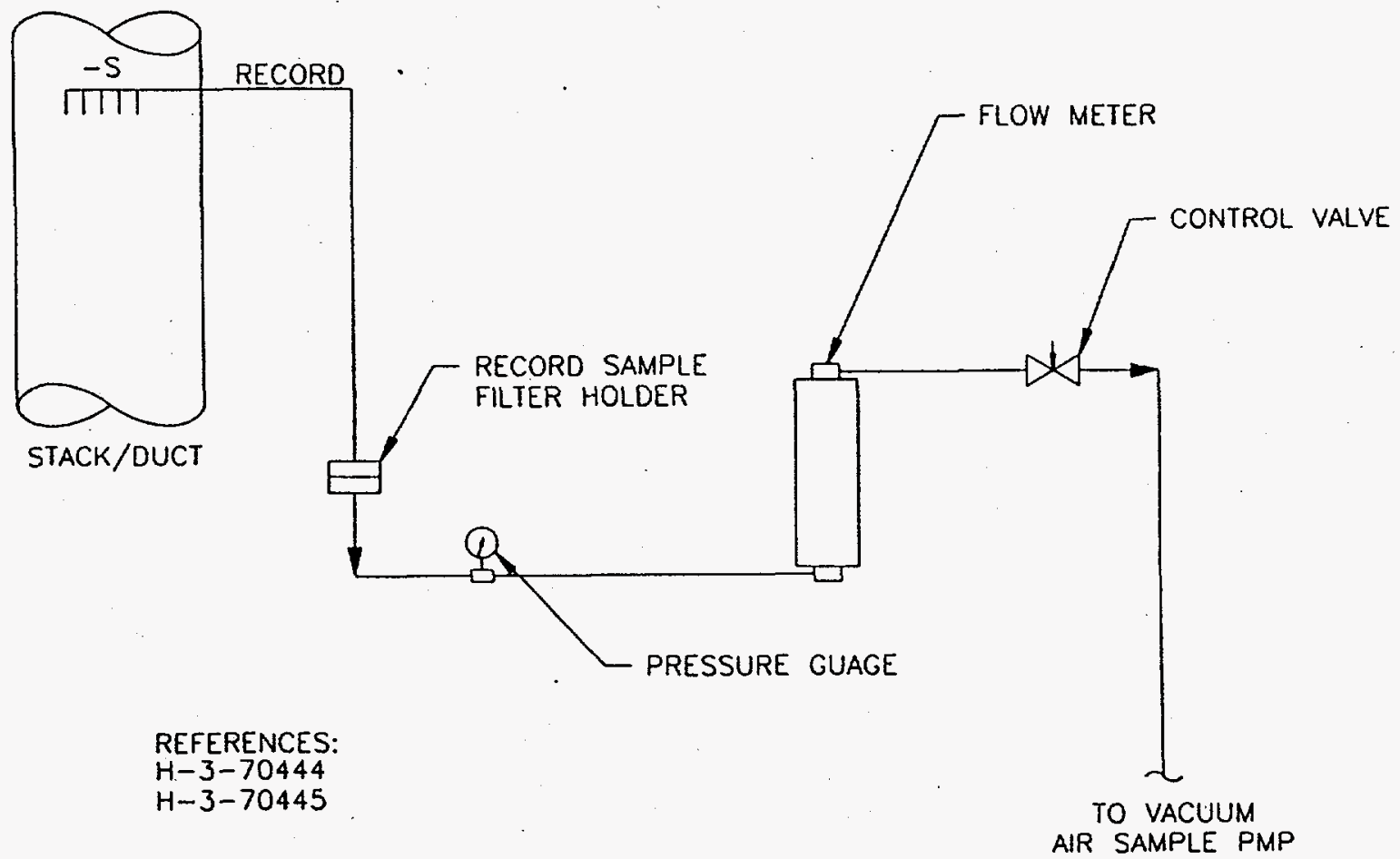

Figure 7.4. Sampling System at Base of 327 Stack

NOTE: Sample flow rates are adjusted by PNL Radiation Protection personnel using procedure in PNL-MA-508, Counting Lab Procedures. Stack velocity measurements are performed by PNL Air Balance personnel using procedure Air Balance -4 .

Loss of sample due to plateout in the sampling system has been estimated to be $5 \%$ for an assumed 1-micron AMAD aerosol at nominal sampler and stack flow rates. Loss calculations were performed using DEPO Version 2.0 (Wong 1991) A 1-micron AMAD polydisperse aerosol was assumed for the calculations based on the assumption that facility operations and controls (HEPA filters) are normal.

Airborne particles are collected on a 47-mm glass fiber filter (Hollingsworth and Vose, Model LB5211). The LB5211 has an estimated retention efficiency for 0.3 micron particles of greater than $99.87 \%$ at face velocities of $180 \mathrm{fpm}$ [extrapolated from tests conducted by Hollingsworth and Vose at face velocities ranging from 11 to $60 \mathrm{fpm}$. (Reference Airborne Emission Monitoring Project Report "Evaluating Effluent Sampling Data," February 1993)]. The filter itself has a maximum rated flow of $26 \mathrm{cfm}$ (Hi-Q Product Catalog) and a pressure drop of about 2 in. water at $4 \mathrm{cfm}$ (Hering 1989).

The sample collection filter is replaced biweekly. The used filter is stored for seven days to permit decay of radon and thoron daughter radionuclides and is then analyzed for radioactivity by a subcontracted analytical laboratory. 
NOTE: Sample collection is performed by PNL Radiation Protection personnel using procedures in PNL-MA-508. Radon and thoron emission measurements are performed separately as described later in this section.

Each particulate emission sample is screened for gross alpha and gross beta activity, and then combined with other stack particulate samples each calendar quarter. The composite sample is analyzed for specific radionuclides, as described in Chapter 9.0. Sample analysis results are evaluated, as described in Section 7.3.

\subsubsection{Main Stack Radon Gas Emission Sampling System (ESP-327-01-T)}

Sampling of radon-220 and radon-222 was initiated in December 1993, following identification of these gases in releases from G-Cell.

NOTE: Releases are from project number 21303 "Production and Recovery of Medical Isotopes from Radioactive Waste." A detailed description of radon/ thoron emission sampling methods employed is provided in an internal report titled "Assessment of 327 Facility Stack Emissions During Fourth Quarter of CY 1993" (in preparation).

The radioactive noble gases, radon-220 (thoron) and radon-222 (radon) are generated by decay of thorium-228 and radium-226 contamination in Cell-G. Special measurements have also indicated a minor source of ${ }^{220} \mathrm{Rn}$ in Cell-A. The radon, being a noble gas, is not removed by either HEPA filters or charcoal bed in the hot cell ventilation exhaust system.

Gas samples for radon determination are withdrawn from the stack using the continuous monitor system (ESP-327-01-T) pictured in Figure 7.5 and 7.6. A Pylon AB-5 with 0.27-L flow-through Lucas cell provides in-place measurement of stack radon gas activity. The Pylon monitor measures alpha activity in a grab sample of stack gas at approximately five hour intervals. The sample is collected by purging the Lucas cell with stack gas for three minutes, then shutting off sample flow and counting alpha emissions within the cell for successive threeminute intervals. The counting data are corrected for counter background, sample decay during transit and collection, and collection and counting efficiency.

Results are then converted to concentration of initial radon gas activity using the Bateman equations to determine the relative activities over time of alpha emitting daughter radionuclides with respect to the alpha-emitting radon gas parent. The rate of decay of the measured counts during the successive counting periods is used to estimate relative concentrations of radon-220 (thoron) and radon-222 (radon). Concentrations are multiplied times stack flow rate to yield radon gas release quantities. 

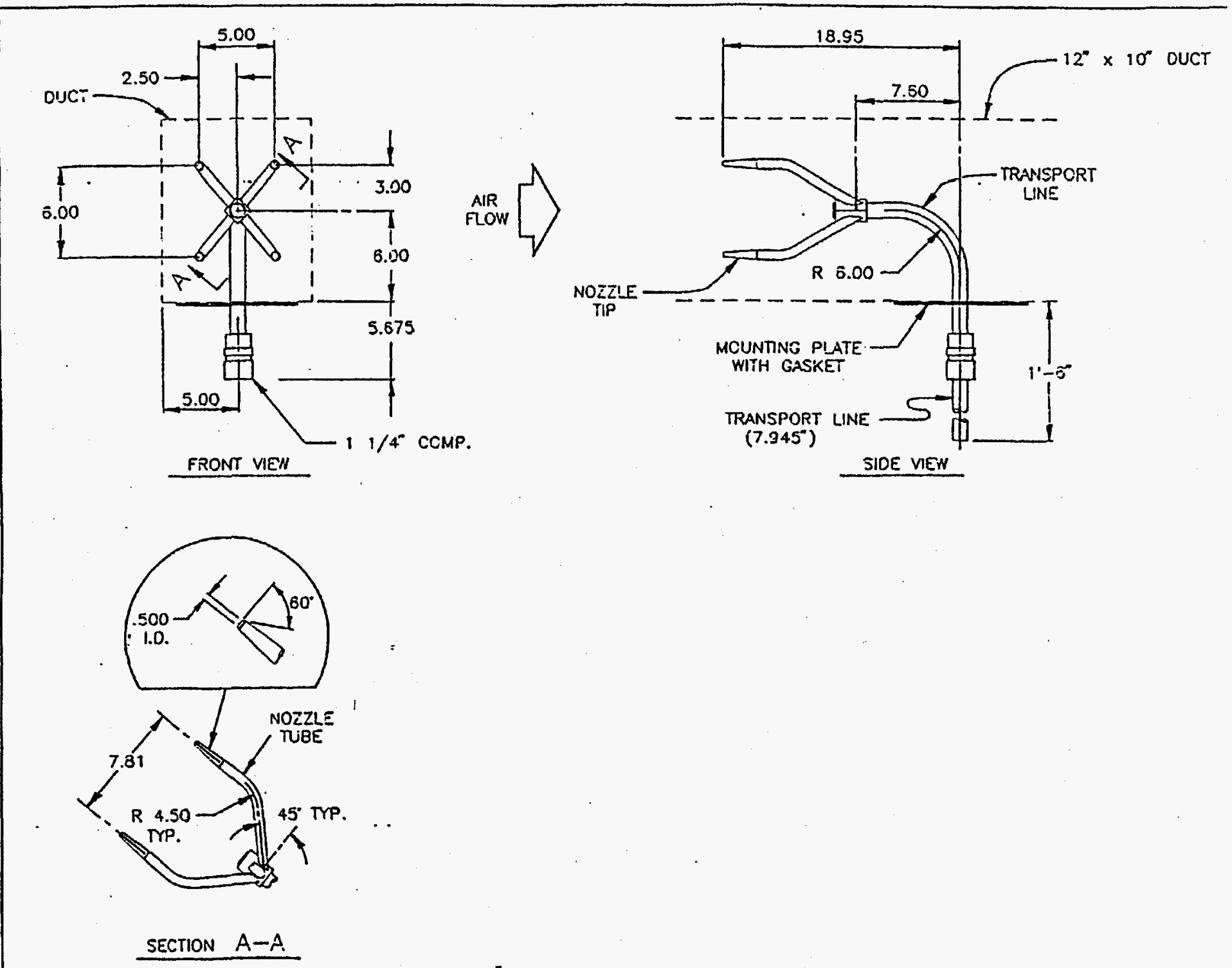

Figure 7.5. 327 Facility Radon Sampling System 


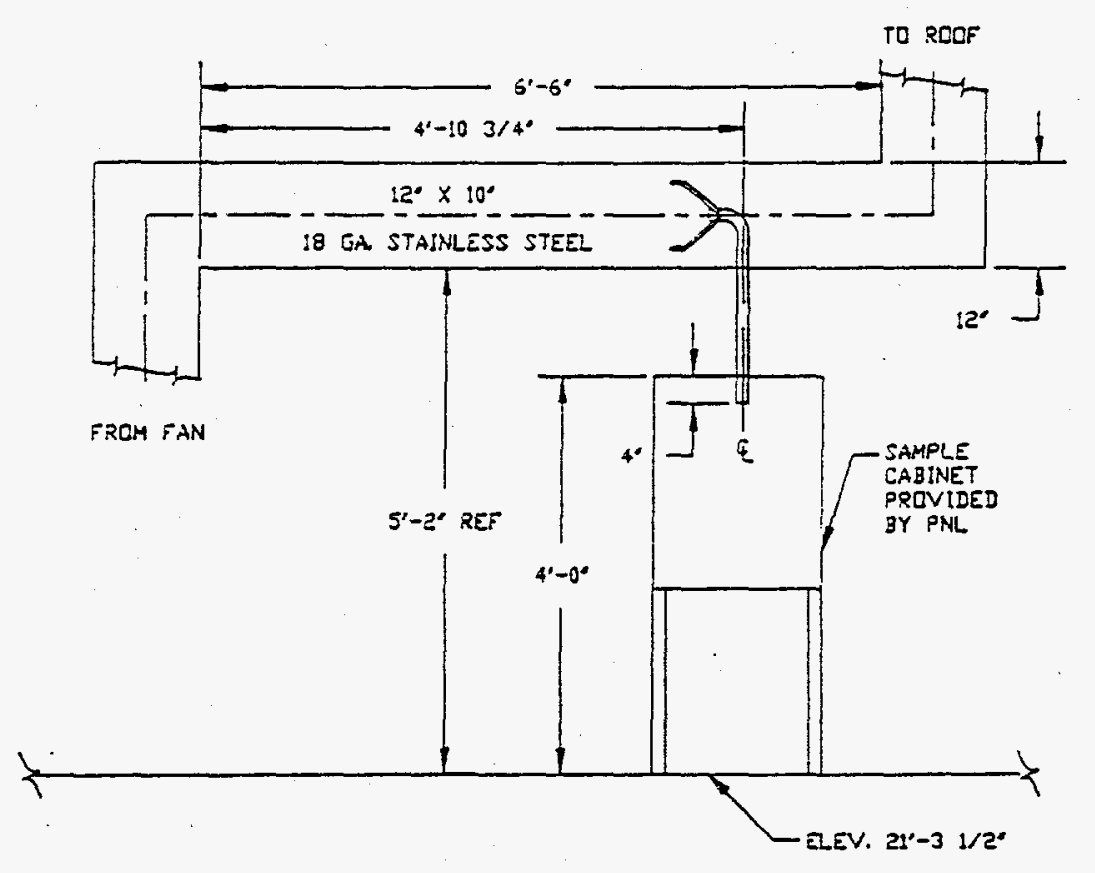

Figure 7.6. 327 Facility Radon Sample Collection System

\subsubsection{Decontamination Cell Particulate Emission Sampling System (ESP-327-02-D)}

An ANSI N13.1(1980) compliant isokinetic particulate radionuclide sampling system (ESP-327-02-D) was installed on the decontamination cell exhaust vent in late 1991. The new system, complies with design requirements in Chapter 6.0.

The system incorporates a four-nozzle isokinetic probe assembly (Figure 7.7) positioned in a horizontal section of the exhaust duct, 5.2 equivalent diameters downstream from flow disturbances and 1.9 equivalent diameters upstream from flow disturbance (Figure 7.8). The probe nozzles are located at the centers of equal areas according to requirements in ANSI N13.1(1980).

A sample transport line extends from the probe assembly to the sample collection filter, just below the horizontal duct section (Figure 7.8). The transport line is stainless steel tubing and is electrically grounded. The entire sampling system is located inside the 327 Facility. The sample collection filter and sample measurement and control equipment are configured, as shown in Figure 7.4.

Loss of sample due to plateout in the sampling system has been estimated to be less than 2\% for an assumed 1-micron AMAD aerosol at nominal sampler and stack flow rates. Loss calculations were performed using DEPO Version 2.0 (Wong 1991). A 1-micron AMAD aerosol was assumed for the calculations based on the assumption that facility operations and controls (HEPA filters) are normal.

Samples of stack airborne particulate emissions are withdrawn through the probe nozzle assembly using a vacuum supply pump. Measurement of duct flow and measurement and control of sample flow rates is performed as described for the 327 Facility Main Stack (Section 7.1.1). 


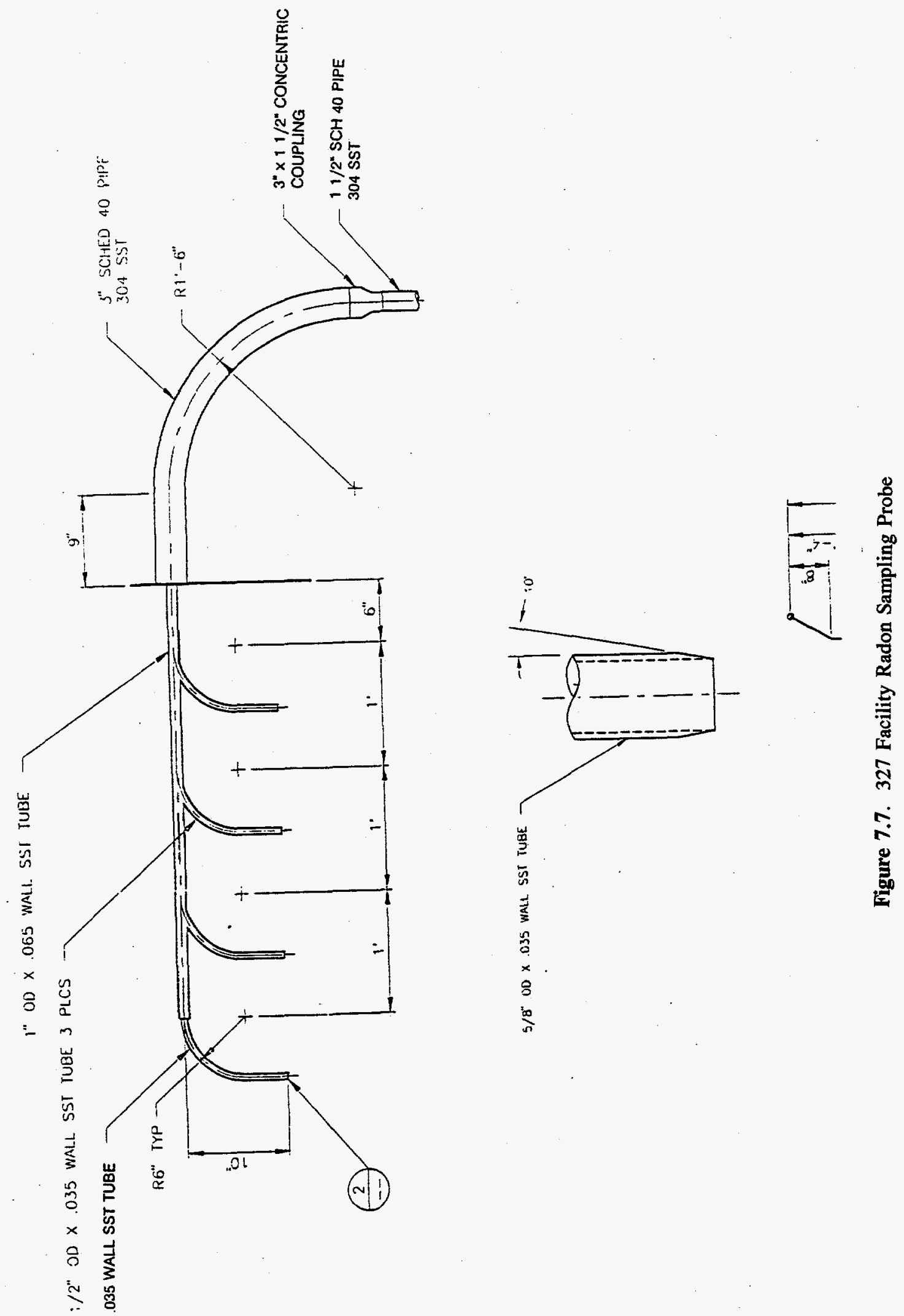




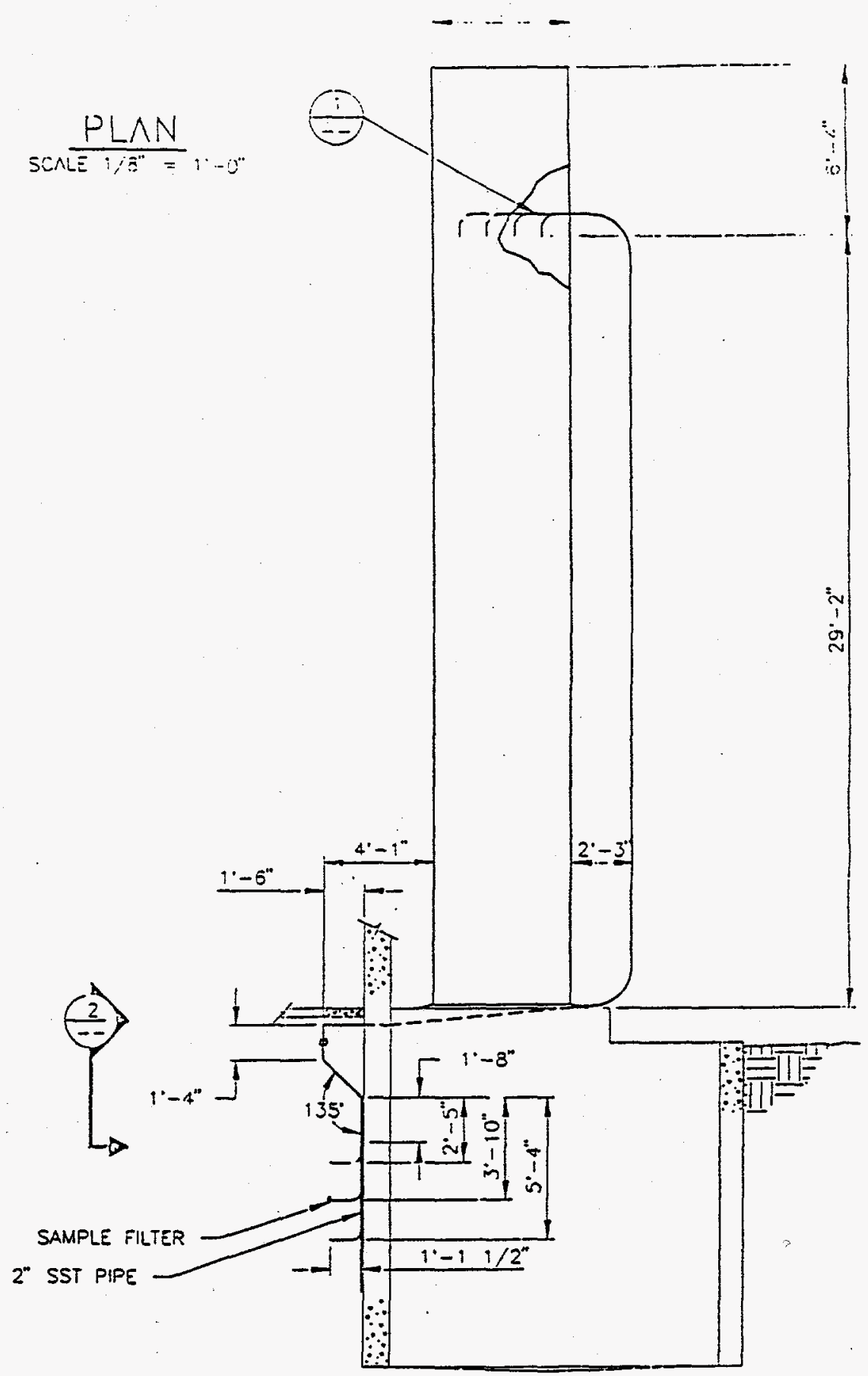

A SECTION

Figure 7.8. Facility Radon Sampling System on 327 Stack 


\subsubsection{Main Stack Continuous Emission Monitoring System (ESP-327-01-T)}

Continuous monitoring of stack emissions for particulate alpha and beta activity and for iodine-131 is required by the OSR in the facility's safety analysis report (Gruber 1987).

The 327 Facility main stack monitoring system (ESP-327-01-T), consists of primary-sample and subsample extraction units, associated sample transport lines, radiation detectors, and sample flow control and measurement components. The radiation detector units consist of a particulate alpha-activity monitor, a particulate beta-activity monitor, and a radioiodine monitor.

The primary sample extraction assembly is composed of four isokinetic sample withdrawal nozzles mounted at even intervals along a header. Each of the nozzles has an inlet diameter of $1.42 \mathrm{~cm}$ (Figure 7.5). The sample extraction assembly is mounted in the stack, on an east-west traverse, just downstream from the stack particulate sampler probe assembly (Figure 7.6).

The sample transport line exits the east wall of the stack, makes a gradual downward turn, and runs vertically along the stack wall to the base of the stack (Figure 7.6). At the stack base, the transport line penetrates the stack concrete pad, and turns horizontally to a westerly direction and into the mechanical equipment room in the facility basement. After a series of bends, to avoid obstacles, the sample line terminates in a vertical "sub-sample" header. Three subsamples of the main sample stream are extracted from the vertical header with vacuum provided by the facility vacuum system (Figure 7.6). Two of the subsamples are directed to the alpha monitor and beta-radioiodine monitor. A third subsample take-off provides backup particulate sampling capability, as well as the supply of stack air used by the stack radon gas sampler discussed in Section 7.1.2. A bypass line is also installed between the subsample header and the vacuum supply so that the flow through the primary sampling system can be adjusted independent of the flow through the subsample lines.

Flow rates through the subsample lines and the bypass line are measured using rotameters. Thus, isokinetic sampling can be achieved by adjusting the monitor unit and bypass flow rates.

NOTE: At the present time, the bypass rotameter is not calibrated and the primary sample flow is not controlled to isokinetic conditions. It is planned to install a calibrated rotameter in the bypass line and adjust the flow rate to achieve isokinetic sampling conditions.

Particulate-alpha activity is monitored using an in-line Eberline Alpha-5 air monitor. Particles are collected on a 3- $\mu \mathrm{m}$ Millipore filter through which a 1.5-cfm subsample of the stack sample stream is drawn. Alpha activity collected on the filter is measured using a solid-state detector with a single-channel pulse height analyzer tuned for alpha energies between 4.65 and $5.65 \mathrm{MeV}$ (plutoniumamericium region). Monitor output is recorded on a chart recorder. Filter media is replaced biweekly to avoid overloading. The monitoring unit is calibrated annually and operational tests are performed monthly. Operating procedures for the stack alpha-CAM monitor are described in PNL-MA-508. 
Particulate-beta activity is measured using a RadECo $250 \mathrm{~L}$ beta monitor. The monitor contains a shielded filter/charcoal cartridge holder. A GM tube is positioned against the collection side of the filter, and a $\mathrm{NaI}$ detector is positioned against the exhaust side of the charcoal cartridge. The filter is the same type used for the record particulate sampler. The monitor is operated at a sample rate of $2 \mathrm{cfm}$ and the filter is changed biweekly to avoid overloading. Monitor output is recorded on a chart recorder. The monitoring unit is calibrated annually and operational checks are performed monthly. Operating procedures for the stack beta-CAM monitor are described in PNL-MA-508.

\subsection{Sampling and Monitoring System Performance}

\subsubsection{Main Stack Sampler Performance}

Performance criteria for sampling are provided in Section 6.0. Two of the criteria concern measurement sensitivity and the third concerns measurement bias. The criteria for bias is based on conformance of the system to design and operational guidance in ANSI N13.1 and DOE/EH-0173T. System description information in Section 7.1 are consistent with the design and operational guidance; thus, the criteria for bias is met.

Sensitivity criteria are stated in terms of detectable offsite dose. According to the criteria, sampling at each major emission point (i.e., EP-327-01-S and EP-327-02-V) should be capable of detecting radionuclide emissions that together would result in a dose of $0.1 \mathrm{mrem}$ to an offsite individual. The criteria also specify that sampling account for specific radionuclides expected to contribute $10 \%$ or more to the annual emission point dose. For example, assuming an emission point potential offsite dose of $0.1 \mathrm{mrem}$ (the lowest dose that would be projected for a major emission point), the $10 \%$ criteria corresponds to the sampling of specific radionuclides that could contribute $0.01 \mathrm{mrem}$. Therefore, it can be assumed that for major emission points, the detectability criteria are met if sampling is capable of measuring radionuclides potentially contributing an offsite dose of $0.01 \mathrm{mrem}$.

Based on a radionuclide inventory assessment for the 327 Facility (Chapter 4.0), significant radionuclides in the 327 Facility are Radon-220, Cesium-137, and Plutonium-238.

Table 7.2 compares detectable release quantities for these radionuclides to the quantity associated with an offsite dose of $0.01 \mathrm{mrem}$. The table shows that sensitivity criteria are easily met with the currently operating emission sampling program. The above analysis, conducted for the main facility stack, also applies to the decontamination cell exhaust sampler, except that the isokinetic sampling ratio of sampler flow rate to stack is 1/170 compared to a ratio for the main stack record sampler of $1 / 11,900$. Thus, the annual detectable quantities are approximately 75 times better (i.e., lower) than those shown in the table for the main stack sampler. 
Table 7.2. Detection of Significant Radionuclides in 327 Stack Emissions

\begin{tabular}{|c|c|c|c|}
\hline Radionuclide & $\begin{array}{l}\text { Analytical Limit } \\
\text { (pCi/sample) }^{(a)}\end{array}$ & $\begin{array}{l}\text { Detectable Annual Release } \\
\text { (Ci) }\end{array}$ & $\begin{array}{l}\text { Release Resulting in } 0.01 \\
\text { Mrem (Ci) }\end{array}$ \\
\hline Beta Activity & $2.8^{(\mathrm{h})}$ & $9.2 \mathrm{E}-7^{(\mathrm{c})}$ & $2.0 \mathrm{E}-3$ \\
\hline Alpha Activity & $0.94^{(\mathrm{h})}$ & $3.1 \mathrm{E}-7^{(\mathrm{c})}$ & $5.4 \mathrm{E}-5$ \\
\hline Cs- 137 & 15 & $7.5 \mathrm{E}-7^{(\mathrm{d})}$ & $2.0 \mathrm{E}-3$ \\
\hline$R n-220$ & $5 \mathrm{pCi} / \mathrm{L}^{(\mathrm{b})}$ & $3.7^{(\mathrm{e})}$ & $90^{(\mathrm{g})}$ \\
\hline $\mathrm{Pu}-238$ & 0.038 & $1.9 \mathrm{E}-\mathrm{g}^{(\mathrm{d})}$ & $5.4 \mathrm{E}-5$ \\
\hline
\end{tabular}

(a) From ITAS Contract No. 108722-A-MI, except for Rn-220.

(b) The minimum detection level for thoron measurements is estimated to be about three times the background reading of the measurement system.

(c) Based on an isokinetic sampling ratio (stack/sampler) of 11,900 (i.e., stack area/probe nozzle inlet area), biweekly samples, particulate sampling efficiency of $95 \%$ (combined isokinetic, transport, and collection efficiency), analytical limit (column 2).

(d) Based on factors listed in b), except self-absorption factor $=1.0$ and quarterly sampling period.

(e) Based on measurement efficiencies described in Assessment of 327 Facility Stack Emissions During Fourth Quarter of CY 1993 (internal report, in preparation) and a nominal stack flow rate of $50,000 \mathrm{cfm}$. This minimum detectable quantity is equivalent to a release of $0.5 \mathrm{mCi}$ of lead-212, the initial significant decay product of thoron.

(f) Based on dose per release factors calculated by CAP-88 and used in 1993 facility radionuclide inventory assessment.

(g) Based on dose factor for lead-212, $0.13 \mathrm{Ci}$ of lead-212 will yield $0.01 \mathrm{mrem}$. This quantity of lead-212 is derived from 90 curies of parent radon-220.

(h) Corrected for $15 \%$ self-absorption loss in sample.

\subsubsection{Monitoring System Performance}

Under the current operating configuration, the stack alpha monitor operates at a sampling rate of $2 \mathrm{cfm}$. Under normal operating conditions, a nominal background count rate of $6 \mathrm{cpm}$ is recorded by the monitor. Calibration tests have shown the monitor to have a detection efficiency for alpha emissions of approximately $10 \%$ in the $4.65-5.65 \mathrm{Mev}$ energy range.

In practice, an increase in the indicated count rate by about a factor of three or more would be clearly distinguishable from background and provides a basis for assessing the minimum release that could be considered to be "detectable" by the monitor. A factor of three count rate increase, or $18 \mathrm{cpm}$, would imply a net filter activity of $12 \mathrm{cpm}$ (gross count rate - background count rate).

Assuming a nominal stack flow rate of $50,000 \mathrm{cfm}$ and a $15 \%$ self-absorption loss, the deposition of alpha emitting radionuclides on the filter yielding twelve counts per minute would imply a stack alpha release of $1.6 \mu \mathrm{Ci}$, assuming there are no sample losses during transport and collection. This assumption is reasonable for small particles, but sampling efficiency decreases as particle size increases due to deposition in the sample lines. For example, sample losses for a monodisperse aerosol of $10-\mu$ median aerodynamic diameter in the sampling system are estimated to be about $90 \%$, implying a detectable release of $10-\mu$ 
particles of $16 \mu \mathrm{Ci}$. [Calculation based on sampling system dimensions in Figure 7.5, 7.6, and 7.9, using DEPO Version 2.0 (Wong, et al. 1991).]

An acute airborne release of $16 \mu \mathrm{Ci}$ plutonium-238 could, under postulated adverse conditions, yield a dose to an offsite receptor of $0.2 \mathrm{mrem}$.

The dose was based on acute release dose factors for the maximum offsite individual in draft 327 Facility Safety Analysis Report.

The detection ability of the stack beta monitor is dependent on the energy of beta emissions radionuclide. Table 7.3 gives representative counting efficiencies for the RadEco 250L beta monitor for various beta energies (based on PNL tests using NIST traceable calibration sources). At a $20 \%$ counting efficiency, a 2-cfm sample rate, and $100 \mathrm{cpm}$ background, a minimum observable release of $10 \mu \mathrm{Ci}$ is calculated, assuming there are no sample losses during transport and collection. For a $10-\mu$ monodisperse aerosol, with a calculated sampling efficiency of $10 \%$ as discussed above, the detectable release would be $130 \mu \mathrm{Ci}$.

An acute airborne release of $130 \mu \mathrm{Ci}$ cesium-137 could, under postulated adverse conditions, yield a dose to an offsite receptor of $0.08 \mathrm{mrem}$.

Monitor alarm thresholds have been established by the current Safety Analysis Report for the 327. Facility (Gruber 1987). Alarm thresholds have been set at $40 \mathrm{cpm}$ alpha and $40,000 \mathrm{cpm}$ beta.

Under conditions assumed above, the maximum dose to an offsite receptor indicated by a stack alpha or beta monitor alarm would be as shown in Table 7.4.

Table 7.3. Beta-CAM Efficiency and Alarm Levels

$\begin{array}{cc}\text { Radionuclide } & \text { \% Counting Efficiency } \\ { }^{14} \mathrm{C} & \\ { }^{14} \mathrm{C} & 4 \\ { }^{99} \mathrm{Tc} & 10 \\ { }^{36} \mathrm{Cl} & 20 \\ { }^{210} \mathrm{Bi} & 20 \\ { }^{234} \mathrm{~Pa} & 10 \\ { }^{137} \mathrm{Cs} & 20 \\ { }^{90} \mathrm{Sr} & 20\end{array}$

(a) Counting efficiency exceeds these values. 
Table 7.4. Stack Particulate Radionuclide Monitoring Capability ${ }^{(a)}$

\begin{tabular}{|c|c|c|c|c|}
\hline & ALPHA & $\left.{ }^{38} \mathrm{Pu}\right)$ & BETA ${ }^{1}$ & \\
\hline & $\begin{array}{c}\text { Minimum } \\
\text { Observable Release }\end{array}$ & $\begin{array}{c}\text { Alarm Level } \\
(40 \mathrm{cpm})\end{array}$ & $\begin{array}{c}\text { Minimum } \\
\text { Observable Release }\end{array}$ & $\begin{array}{r}\text { Alarm Level } \\
(40,000 \mathrm{cpm})\end{array}$ \\
\hline $\begin{array}{l}\text { Acute Stack } \\
\text { Release (uCi) }\end{array}$ & $1.6-16 \mu \mathrm{Ci}$ & $4.5-46 \mu \mathrm{Ci}$ & $13-130 \mu \mathrm{Ci}$ & $2.6-26 \mathrm{mCi}$ \\
\hline $\begin{array}{l}\text { Offsite Receptor } \\
\text { Dose (mrem) }\end{array}$ & $0.02-0.2 \mathrm{mrem}$ & $0.06-0.6 \mathrm{mrem}$ & $0.008-0.08$ mrem & $2-20 \mathrm{mrem}$ \\
\hline
\end{tabular}

(a) Capability over range of system transport collection efficiencies from small-sized aerosols (collection efficiency assumed to be $100 \%$ ) to $10-\mu$, monodisperse aerosol (collection efficiency estimated to be $10 \%$ ).

\subsection{Handling of Sampling and Monitoring Data}

The continuous ${ }^{131}$ I monitor uses a NaI detector and a single-channel analyzer to measure ${ }^{131} \mathrm{I}$ photon emissions in the $364-\mathrm{KeV}$ photopeak region. Efficiency for a mock ${ }^{131}$ I source $\left({ }^{133} \mathrm{Ba}\right)$ is on the order of 5 to $6 \%$, which corresponds to an ${ }^{131}$ I efficiency of 6 to $7 \%$ (364-KeV photon from ${ }^{131}$ I has $82 \%$ yield). Because the charcoal also adsorbs radon and thoron gases present in the exhaust stream, a gradual buildup of radon/thoron daughters is observed over the sample period. This buildup reaches an equilibrium count rate of around $100 \mathrm{cpm}$ within a few days of adsorber media exchange.

The iodine monitor alarm level is set for $10,000 \mathrm{cpm}$. This level represents a stack ${ }^{131} \mathrm{I}$ 4-h average concentration of $5.6 \mathrm{E}-9 \mu \mathrm{Ci} / \mathrm{mL}$ assuming a 2 -cfm count rate, $100 \%$ adsorber retention efficiency for ${ }^{131} \mathrm{I}, 6 \%$ detector efficiency, and negligible background contribution and line loss.

Results obtained from the record sampling program are used to evaluate existing facility emission levels and to calculate annual emission quantities for compliance determination and reporting purposes. Results are also used to prepare a quarterly emission trends report.

Particulate samples are collected as described in Section 7.1. Analysis of samples by a laboratory is described in Chapter 9 . Data is evaluated as described in an internal procedure titled: "Evaluating Effluent Sampling Data" (issued February 1993). Data evaluation procedures are based on guidance in DOE/EH-0173T "Environmental Regulatory Guide for Radiological Effluent Monitoring and Environmental Surveillance" and EPA 520/1-80-012 "Upgrading Environmental Radiation Data."

Airborne emission sampling data are reviewed for anomalies and trends. Provisional release estimates are updated throughout the sampling year (calendar year) as data are received. At the completion of the calendar year, data are reviewed and the provisional release estimate is refined as necessary to account for anomalies or missing data, as well as a significantly skewed data set. Anomalous data are investigated and conclusions of the investigation are documented. 
Final release quantities include corrections for isokinetic sampling efficiency, sample transport losses, sample self-absorption, decay, counting efficiency, background, and collection media efficiency.

\subsection{Calibration and Maintenance of Equipment}

Sampling and monitoring equipment are maintained and calibrated according to predetermined schedules. Stack flow rates are measured using a standard-type pilot tube that is recognized by EPA as a primary calibration standard. Rotameters are calibrated or checked as described in preceding sections.

Radiation monitoring equipment is calibrated annually by the Hanford Instrument Evaluations Section of PNL. This group has responsibility for calibration of all portable radiation protection instrumentation at Hanford.

Sampling systems are checked weekly by the PNL Radiation Protection Section for proper flow rate setting and system operation. Monitoring systems are similarly checked each workday. In addition, response and alarm tests are conducted on monitoring systems monthly.

\subsection{Alternative Sampling Methods}

The continuous beta activity monitor uses the same type of filter media and sampler flow rate as the record sampling system; thus, the beta monitor provides backup capability in event of problems with the record sampler.

If a continuous monitoring system fails such that safety requirements in the facility SAR are not met, major facility operations are put on standby until an adequate monitoring program is reestablished. All monitoring systems have replacement units available, so down time is usually limited to no more than a few hours.

Alternative methods exist for assessing impacts of facility emissions. Workplace air monitoring systems provide evidence of the presence or absence of radionuclides in room air. Contamination surveys, routinely performed throughout the facility, provide additional evidence of contamination spreads. Air emission control systems are routinely checked for leaks. Differential pressure gauges installed across each filter bank would provide evidence of filter plugging or breakthrough. An extensive environmental surveillance program is operated for the Hanford Site by PNL. This program is described in detail in the Hanford Site Environmental Monitoring Plan. The program performs ambient air sampling around the 300 Area perimeter as well as along the Hanford Site boundary and in adjacent communities. In addition to ambient air sampling, the environmental surveillance program samples groundwater, river water, drinking water, foodstuffs, soil, native vegetation, and aquatic and terrestrial animals. Annual reports issued by the Hanford Environmental Surveillance Program document the results of these samples.

\subsection{References}

American National Standards Institute (ANSI). 1980. "Guide to Sampling Airborne Radioactive Materials in Nuclear Facilities." ANSI N13.1-1980.

Gruber, W. J. 1987. Postirradiation Testing Laboratory (327 Building) Safety Analysis Report. HEDL-TC-1009, Hanford Engineering Development Laboratory, Richland, Washington. 
Hering, S. V., ed. 1989. Air Sampling Instruments, 7th Edition. American Conference of Governmental Industrial Hygienists, Cincinnati, Ohio.

Napier, B. A., R. A. Peloquin, D. L. Strenge, and J. V. Ramsdell. 1988. GENII - The Hanford Environmental Dosimetry Software System. PNL-6584. Battelle, Pacific Northwest Laboratory, Richland, Washington.

Wong, F. S., N. K. Anand, and A. R. McFarland. 1991. Software Program for Characterizing Aerosol Penetration Through Transport Systems. Aerosol Technology Laboratory, Department of Mechanical Engineering, Texas A\&M University. 


\subsection{Historical Monitoring/Sampling Data for Effluent Streams}

The 327 Facility was built in 1953 for storage, transfer, and destructive and nondestructive examinations of irradiated reactor fuel and structural materials. Some of the effluent streams from the facility have been sampled and monitored over the history of operations. Information from historical sampling and monitoring is provided in this section to aid in providing a basis for future monitoring needs. A description of historic sampling and monitoring data under normal operating conditions for air and liquid effluent streams is given in Section 8.1. Estimates of the types of releases and release pathways experienced during plant operations under upset conditions are given in Section 8.2.

\subsection{Normal Conditions}

Sampling and monitoring of some of the air and liquid effluent streams have occurred since the 327 Facility started operations. The types and location of sampling and monitoring and methods of analysis are described in this section for normal operations. Discussion is generally limited to the past seven years since this time period is the most relevant to future operations and monitoring needs; the 327 Facility was transferred to PNL in June 1987.

\subsubsection{Air Emission Monitoring/Sampling}

Air emissions from the 327 Facility has been sampled for radioactive particles at two locations: at the main exhaust stack and at the decontamination facility stack. Continuous air monitoring has also been done at the main exhaust stack. The monitoring systems currently in place (see Section 7.0) have not been significantly changed over the past seven years. The sampling system was updated in 1993. Monitoring of gross alpha and beta and sampling of ${ }^{131} I$, gross alpha, and beta were provided. In addition, sampling of stack gases to determine the quantity of radon and thoron released was instituted in 1993. As described in Section 7.0, a probe array with several sample nozzles located in the duct just upstream of the 327 stack (ESP-327-01-S) has been used to provide continuous air monitoring and weekly record samples. A similar system in the decontamination facility stack (ESP-327-02-D) provided information on gaseous and particulate emissions from the decontamination facility. See Chapter 7 for additional information.

A portion of the stack gas was passed through continuous air monitors that detected alpha and beta activity. Samples were collected by passing a continuous stream of the stack air through a particulate filter and charcoal bed. The filter samples were analyzed for total alpha and total beta, and the charcoal beds were analyzed for ${ }^{131} \mathbf{I}$.

In 1987, control of facility operations was transferred from WHC to PNL, and the analyses were done as described in Section 9.0. The MDL under the present analysis method varies from sample to sample because it is sensitive to changes in background (which are highly variable) and counting time.

Estimated emissions calculated from the sampling data from 1987 to 1994 are shown in Tables 8.1 and 8.2. In addition to the emission listed, a total of $85 \mathrm{Ci}$ of radon-220 (thoron) and $1.5 \mathrm{Ci}$ radon-222 (radon) were measured from the main stack in 1993. 
Table 8.1. 327 Facility Main Stack Sampling Data

\begin{tabular}{|c|c|c|c|}
\hline Year & Gross Alpha & Gross Beta & ${ }^{131} I$ \\
\hline 1987 Total, $\mathrm{Ci} / \mathrm{yr}$ & $<1.0 \mathrm{E}-6$ & $<2.3 \mathrm{E}-6$ & $<6.5 \mathrm{E}-5$ \\
\hline 1988 Total, $\mathrm{Ci} / \mathrm{yr}$ & $2.6 \mathrm{E}-6$ & $8.6 \mathrm{E}-5$ & $<2.7 \mathrm{E}-4$ \\
\hline 1989 Total, Ci/yr & $5.2 \mathrm{E}-7$ & $7.6 \mathrm{E}-5$ & $<2.7 \mathrm{E}-5$ \\
\hline 1990 Total, Ci/yr & $6.3 \mathrm{E}-7$ & $1.4 \mathrm{E}-5$ & $<2.1 \mathrm{E}-5$ \\
\hline 1991 Total, Ci/yr & 4.7E-7 & $1.3 E-5$ & \\
\hline 1992 Total, $\mathrm{Ci} / \mathrm{yr}$ & $8.5 \mathrm{E}-7$ & $2.4 \mathrm{E}-6$ & \\
\hline 1993 Total, $\mathrm{Ci} / \mathrm{yr}$ & $2.6 \mathrm{E}-7$ & $2.8 \mathrm{E}-6$ & \\
\hline
\end{tabular}

Table 8.2. 327 Decontamination Facility Stack Sampling Data

\begin{tabular}{|c|c|c|c|}
\hline Year & Total Alpha & Total Beta & ${ }^{131} I$ \\
\hline 1987 Total, Ci/yr & $<1.6 \mathrm{E}-8$ & $<5.9 \mathrm{E}-8$ & $<5.3 \mathrm{E}-7$ \\
\hline $1988 \mathrm{Total}, \mathrm{Ci} / \mathrm{yr}$ & 4.3E-8 & $1.4 \mathrm{E}-6$ & $<5.5 \mathrm{E}-7$ \\
\hline 1989 Total, Ci/yr & $9.4 \mathrm{E}-9$ & $1.0 \mathrm{E}-6$ & \\
\hline 1990 Total, $\mathrm{Ci} / \mathrm{yr}$ & $7.8 \mathrm{E}-9$ & 9.9E-8 & $<4.2 \mathrm{E}-7$ \\
\hline 1991 Total, $\mathrm{Ci} / \mathrm{yr}$ & 9.9E-9 & $1.1 \mathrm{E}-7$ & \\
\hline 1992 Total, $\mathrm{Ci} / \mathrm{yr}$ & $1.1 \mathrm{E}-7$ & 9.3E-7 & \\
\hline 1993 Total, Ci/yr & 2.7E-9 & $3.1 \mathrm{E}-8$ & \\
\hline
\end{tabular}

A few values in Table 8.1 are reported as less-than values because samples, collected for analysis on a weekly basis, often contained levels of contaminant lower than the detection limit. Each of the weekly measurements were summed, including those assigned with a value of less than detection limit, to obtain the total for the year.

The deficiencies in the sampling method are described in Section 7.0. Because of these deficiencies, the values given in Table 8.1 have some degree of uncertainty. However, these data show that releases of contaminant from the stack can be measured. A longer collection period (2-week samples) was instated in 1991 to provide larger samples with higher contaminant concentrations, which allow better resolution of the data.

\subsubsection{Liquid Effluent Monitoring/Sampling}

Liquid waste streams in the 327 Facility have been served by four systems as described in Section 4.0. Table 8.3 summarizes the type of historical monitoring/ sampling each system has had. As noted in Table 8.3, no monitoring of the SNS or PS took place at the 327 Facility. However, sampling of the composite liquid waste from the 300 Area was done before the waste was disposed of in trenches. A brief description of the sampling and analysis program is given by McCarthy (1990). Since this sampling program is not specific to the 327 Facility, the historical data from it are not given in this report. 
Table 8.3. Summary of Historical Liquid Monitoring/Sampling

\begin{tabular}{ll}
\multicolumn{1}{c}{ System } & \multicolumn{1}{c}{ Notes } \\
\hline Sanitary sewer & $\begin{array}{l}\text { No sampling or monitoring at } 327 \text { Facility; } \\
\text { sampled as composite with other 300 Area } \\
\text { SNS. }\end{array}$ \\
Process sewer & $\begin{array}{l}\text { No sampling or monitoring at } 327 \text { Facility; } \\
\text { sampled as composite with other 300 Area PS; } \\
\text { grab samples taken in 1989. }\end{array}$ \\
Retention process sewer & $\begin{array}{l}\text { Monitored at diverter station in 327 Facility; } \\
\text { grab samples taken in 1989; sampled as } \\
\text { composite with other 300 Area PS. }\end{array}$ \\
RLWS & Sampled at 340 Facility after transfer.
\end{tabular}

The RPS was monitored with a counting instrument that detected excessive levels of radioactivity (gamma detector) in the liquid waste. The liquid passed through a diverter station supplied with a probe and a detection instrument. The diverter automatically diverted RPS effluent to the RLWS line when radionuclides were detected at or above $5 \times 10^{-5} \mathrm{Ci} / \mathrm{mL}$ of ${ }^{137} \mathrm{Cs}$ equivalent. The diverter station automatically reset when the level of radioactivity dropped below the set point. Diverter alarms were annunciated at various locations in the 327 Facility when diversion occurred and a sample was taken automatically. Data from the monitor were not recorded.

Normally, the 327 Facility RPS passed through the diverter station and into the 307 basins where it was screened a second time before entering the 300 Area PS lines. Sampling of the composite liquid waste from all 300 Area PS lines was done before the liquid was discharged to the 300 Area process trenches. A description of the sampling and analysis program is provided by McCarthy (1990). Sampling data from this program are not specific to 327 Facility PS lines and thus are not included in this report.

The RLWS served liquid waste streams expected to contain radioactive liquids. This system was composed of pipes within the 327 Facility. Waste flowed through the pipes to holding tanks in the $\mathbf{3 4 0}$ Facility via the 300 Area RLWS line (a double-containment pipe provided with a sump alarm if leakage occurred from the primary pipe). Composite water in the holding tanks at the 340 Facility was sampled before being transferred to the 200 Area by rail car. Since the RLWS stream was not released to the environment, the sampling program is not pertinent to the FEMP.

No historical monitoring or sampling of nonradioactive constituents in the 327 Facility has occurred except for grab samples taken in 1989. A PS line in the basement of the 327 Facility was sampled three times in May and June 1989. The samples were scheduled, collected, preserved, shipped, and analyzed according to the procedures of EPA protocol SW-846 (EPA 1986). A detailed description of the collection and analysis is given in the Waste Stream Characterization Report (Westinghouse Hanford Company 1989). Data from this effort are shown in Appendix D. The data indicate that releases from the 


\subsection{Upset Conditions}


Table 8.4. (contd)

Date

Class

$1 / 25 / 93$

$9 / 29 / 93$

$10 / 26 / 93$

$12 / 30 / 93$

$3 / 22 / 94$

$4 / 15 / 94$

$4 / 27 / 94$

ONO
Contained radioactive liquid leak from an RLWS isolation valve in the 327 basement, and subsequent shoe cover contamination of two staff.

ONO During controlled experiment, radon released and reached the inlet to the facility ventilation system. The CAM alarmed.

ONO During maintenance, the fire alarm sounded and the facility was evacuated.

ONO Beta continuous air monitor alarmed during transfer of a waste drum to the 327 canyon.

ONO During a facility fire protection inspection, the fire protection engineer noticed that air appeared to be following from a radiological buffer area to an office hallway. Condition was verified and there was no spread of contamination.

ONO A PNL radiation worker was exiting the changeroom of the 327 Facility and alarmed the Personnel Contamination Monitor. The RPT confirmed 5,000 dpm of beta-gamma around the nose.

ONO After completing a job in a radiologically controlled area that required respiratory protection, an RPT noticed that an electrician had entered the area, in violation of a posted sign and warning light.

ONO A fire alarm caused the 327 Facility to be evacuated. WHC was filling a water storage tank and throttled a valve, sending a pressure spike through the water grid. This activated the facility fire protection sprinkler system alarm.

Before 1987, upset conditions have included fires in some of the hot cells and floods in the 327 basement. One incident in 1986 involved the burning of a flammable liquid in the SERF Cell (Gruber 1987, pp. 6-9). Following a manipulator changeout, the nitrogen atmosphere in the cell, which contained alcohol, was not turned back on. A spark initiated a fire in the cell.

Another incident in 1976 involved a spill of $\mathrm{NaK}$ and a flammable liquid in a drain in F Cell. A reaction occurred that caused dispersion of the flammable liquid into fine droplets. The droplets ignited, and F Cell overpressurized from the ensuing fire that lasted about thirty minutes and released an estimated $27-\mu \mathrm{Ci}$ MFPs out the stack (Gruber 1987).

In 1980, the decontamination hood was flooded, which resulted in contamination of the cell but no releases to the environment. Subsequent changes in piping have eliminated the possibility of a similar event in the future. 


\subsection{References}

Because corrective actions in the form of engineered and administrative controls have been instated after each event, these types of events are not expected to occur in the future as upset conditions. However, even if cell fires did occur (flammable solvents and alkali metals may be used in future operations), the airborne release would exhaust to the main stack, which is monitored. Potential floods in the basement would drain to the RLWS, which is sent to the 340 Facility and not released to the environment. Information from past upset conditions does not indicate a need for monitoring of other pathways.

Other upset conditions, such as procedural or administrative control violations, have occurred that have been of a minor nature and have not required formal reporting. None of these incidences have indicated additional monitoring.

Environmental Protection Agency. 1986. Test Methods for Evaluating Solid Waste, Physical/Chemical Methods, Third Edition. SW-846, Washington, D.C.

Gruber, W. J., coordinator. 1987. Postirradiation Testing Laboratory (327 Building) Safety Analysis Report. HEDL-TC-1009, Hanford Engineering Development Laboratory, Richland, Washington.

McCarthy, M. J. 1990. Westinghouse Hanford Company Effluent Report for 300, 400, and 1100 Area Operations for Calendar Year 1989. WHC-EP-0267-1, Westinghouse Hanford Company, Richland, Washington.

Westinghouse Hanford Company. 1989. Waste Stream Characterization Report. WHC-EP-0287, Westinghouse Hanford Company, Richland, Washington. 


\subsection{Analysis of Effluent Samples}

This section provides information on the analytical laboratories and procedures used to analyze samples collected in support of the PNL effluent monitoring program. As stated in previous sections, these samples may contain radioactivity associated with emissions from the 327 Facility main stack. Since liquid discharges from the 327 Facility are sampled by WHC at the point of discharge to the uncontrolled environment, and since sampling for chemical constituents is currently not performed, analysis of PNL-collected effluent samples is limited to determination of radioactivity in samples collected from the main facility stack.

Section 7.0 describes the types of samples collected by the main facility stack sampling system. These are particulate radionuclides on filter paper, and radon gas. The laboratories and procedures used to perform these analyses are described in Section 9.1. Section 9.2 provides a description of the chain-of-custody procedures employed by PNL and its supporting analytical laboratories.

\subsection{Analytical Procedures}

Analytical procedures for alpha and beta particulate radioactivity, radon and thoron, and isotopic analysis are provided in this section. The principal radionuclides in 327 Facility emissions are described in Section 6.0. These radionuclides are detectable using procedures described in this section.

\subsubsection{Determination of Alpha and Beta Activity on Particulate Air Filter}

Particulate air filter samples are collected every two weeks, as described in Section 7.0. The samples are initially delivered to a laboratory at the 3745 Facility operated by PNL's Radiation Protection Section. The samples are held at the 3745 Facility to allow adequate decay of Radon daughter radionuclides.

Record Alpha and Beta Activity Determination by ITAS-Richland

Following the hold time for Radon daughter decay, each particulate filter is delivered to the International Technology Analytical Services-Richland (ITAS) analytical laboratory. ITAS operates under contract to Battelle and performs analyses on a large variety of effluent and environmental samples. Work under the contract is performed according to documented requirements in a Statement of Work.

Samples are received, logged in, classified, and analyzed according to procedures documented as Standard Operating Procedures (SOPs).

The ITAS particulate alpha and beta analysis method is described in SOP 30-05. Samples are counted on an alpha and beta proportional counter. The counters are operated with a full open energy window and are calibrated using ${ }^{239} \mathrm{Pu}$ and ${ }^{90} \mathrm{Sr}$ sources corrected for self-absorption. As specified in the Statement of Work, required detection levels are $0.8-\mathrm{pCi}$ alpha and $2.4-\mathrm{pCi}$ beta activity on a filter for Type I and Type II errors of 0.05 . For the 327 Facility stack, this equates to a detectable concentration of $4 \mathrm{E}-16 \mu \mathrm{Ci} / \mathrm{cm}^{3}$ alpha and $1 \mathrm{E}-15 \mu \mathrm{Ci} / \mathrm{cm}^{3}$ beta. Section 7.0 addresses the performance capability of the particulate emission sampling program in terms of detectable offsite dose. 


\subsubsection{Determination of Radon and Thoron}

Sampling of radon-220 and radon-222 was initiated in December 1993 following identification of these gases in releases from the facility. Section 7.1.2 discusses sampling of these isotopes and describes the method used to determine their release.

\subsubsection{Isotopic Analysis}

The record particulate filters analyzed by ITAS for alpha and beta discussed in Section 9.1.1 are further analyzed for ${ }^{90} \mathrm{Sr},{ }^{241} \mathrm{Am},{ }^{238} \mathrm{Pu},{ }^{239 / 240} \mathrm{Pu}$, and by gamma scan. These analyses are performed by ITAS on particulate samples composited on a quarterly basis.

The ITAS composite preparation and analysis methods used for the above isotopes are listed in Table 9.1. As specified in the Statement of Work, required detection levels are also listed in Table 9.1.

Before digesting the particulate filters for isotopic analysis, the filters are grouped by quarter and transferred to a standard geometry container for counting on the gamma detectors. Hyper Pure Germanium (HPGE) detectors are used to detect isotopes with gamma ray energies between 5 and $200 \mathrm{Kev}$. The "n-type" HPGE or Low Energy Photon Detectors (LEPD)are generally used for isotopes with gamma ray energies less than $200 \mathrm{Kev}$. Activity is determined using software provided by a Canberra Nuclear Data acquisition system.

Following the gamma scan, the quarterly groups are digested and the radionuclides of interest are separated from other radionuclides and the sample matrix by radiochemical procedures. The activity of strontium- 90 is determined by the radiochemical separation and counting of a daughter, yttrium-90. The strontium is separated from other elements radiochemically, then yttrium- 90 is permitted to grow into equilibrium with the strontium-90. The yttrium-90 is then separated and processed to determine the chemical recovery and counted on a low background beta proportional counter. The quantity of strontium- 90 is then determined based on the quantity of the daughter yttrium- 90 produced.

Plutonium is separated from other elements and the sample matrix by adsorption on an anion exchange column. The plutonium is then processed radiochemically and electroplated or coprecipitated as rare earth fluorides. The isotopic activity of the deposited material is determined by alpha spectrometry. Following the removal of the plutonium, the sample matrix is further processed radiochemically

Table 9.1. Isotopic Separation and Analysis Methods

Method

Air Filter Preparation and Compositing Gamma Analysis Sample Preparation, All Matrices

Electrodeposition Procedure for the Actinides Strontium Determination for Environmental Matrices Isotopic Plutonium Determination, All Matrices Isotopic Americium/Curium Determination

\section{ITAS SOP MDA, pCi}

$\begin{array}{cc}\text { RD-3242 } & \text {-NA- } \\ \text { RD-3219 } & 200^{(\text {a) }} \\ \text { 30-ED-02 } & \text {-NA- } \\ \text { 20-Sr-03 } & 10 \\ \text { RD-3209 } & 1 \\ \text { RD-3206 } & 1\end{array}$

(a) MDA for $\mathrm{Cs}-137$ 
and the americium and curium removed by passing the sample through a cation exchange column. The americium and curium are eluted from the column and either electroplated or coprecipitated. As with the plutonium, isotopic activity of the deposited material is determined by alpha spectrometry.

\subsection{Chain-of-Custody Procedures}

Chain-of-custody procedures for air emission samples are documented in PNL-MA-508. Procedures include provisions for transfer of samples between operational staff, to and from regulated storage areas, and to the analytical laboratory. Both PNL and its offsite analytical services contractor implement chain of custody within the Laboratory.

Analytical laboratory chain-of-custody procedures are documented in PNL-MA-508 for the preliminary analyses of particulate emission samples, and in ITAS SOP RD-20800 and Laboratory Support Manual RD-2201 for record analysis of particulate air filters and silica gel collectors.

Samples are stored for one year before being discarded. 


\subsection{Notifications and Reporting Requirements}

\subsection{Off-Normal Event Notification and Reporting}

This section identifies the requirements and provides an overview of the procedural steps for the notification, investigation, and reporting of all environmental off-normal events for Battelle, Pacific Northwest Laboratory operations. This section provides a basic outline of the environmental off-normal event information available in PNL-MA-7, Off-Normal Event Reporting System, and DOE 5000.3B, "Occurrence Reporting and Processing of Operations Information."

NOTE: In this section, all discussion of off-normal events refers only to the environmental category of these events.

The basic objective of the system is to gather data on environmental off-normal events to

- obtain immediate resources required to deal with the off-normal event and coordinate activities

- alert PNL management to off-normal operating conditions and activities

- make proper notification to DOE and regulatory agencies

- allow management to make decisions concerning any corrective action to prevent recurrence

- perform analyses using all available data to identify any trends in events

- distribute findings useful to others.

10.1.1 Definitions

Emergency: The most serious occurrence category requiring an increased alert status for onsite personnel and, in specified cases, for offsite authorities.

Event: A real-time occurrence (e.g., pipe break, valve failure, loss of power).

Federally permitted release: Any release that satisfies the definition of "federally permitted release" in 40. CFR 302.3.

Hazardous substance or material: Any solid, liquid, or gaseous material that satisfies the regulatory definition provided in 40 CFR 300 . Oil is excluded from this definition.

Logbook only off-normal event: An off-normal event that has a low potential for creating a serious safety hazard.

Occurrence Classifier: A senior staff member who is knowledgeable and experienced in off-normal event reporting who concurs with the facility manager on the final decision on categorizing occurrences. 
Occurrence Report: A written evaluation of an event or condition that is prepared in sufficient detail to enable a reader to assess its significance, consequences, or implications, and to evaluate the actions being proposed or employed to correct the condition or to avoid recurrence.

Off-normal event (ONE): An unplanned or unexpected event, or the discovery of a deficiency in a procedure, plan, or system. The event must have real or potentially undesirable effects on personnel, equipment, facilities, or programs. Effects can include damage, loss, failure, or delays that can have undesirable results.

Off-normal occurrence: Abnormal or unplanned events or conditions that adversely affect, potentially affect, or are indicative of degradation in the safety, security, environmental or health protection performance, or operation of a facility.

Oil: Oil of any kind or in any form, including but not limited to petroleum, fuel oil, sludge, oil refuse, and oil mixed with wastes other than dredged soil.

Release: Any spilling, leaking, pumping, pouring, emitting, emptying, discharging, injecting, escaping, leaching, dumping, or otherwise disposing of substances into the environment. This includes abandoning/discarding any type of receptacle containing substances or the stockpiling of a reportable quantity of a hazardous substance in unenclosed containment structures.

Reportable occurrence: Events or conditions to be reported in accordance with the criteria defined in DOE 5000.3A.

Reportable quantity: For any Comprehensive Environmental Response, Compensation, and Liability Act (CERCLA) hazardous substance, the quantity established in Table 302.4 and Appendix B of 40 CFR 302, the release of which requires notification unless federally permitted.

Unusual occurrence: A nonemergency occurrence that has significant impact, or potential for impact, on safety, environment, health, security, or operations.

\subsubsection{Categorization of $\mathrm{ONE}$}

ONE reporting requirements vary depending primarily on the categorization of the event. A ONE may be categorized as an emergency, an unusual occurrence, an off-normal occurrence, or a logbook entry only.

NOTE: Any of the above categories could easily become elevated to a higher severity event.

PNL-MA-7, Appendix B, "Categorization of Reportable Occurrences, " provides a generic list of occurrences to guide the occurrence classifier in categorizing reportable occurrences. Occurrences have been arranged into nine groups that relate to DOE operations. Only the environmental group is addressed in this section.

Within each environmental grouping is a list of occurrences derived from DOE 5000.3A. They are categorized as emergency, unusual occurrences, or 
off-normal occurrences. The list presents a minimum set of standards that reflect the DOE-desired degree of significance in categorization. The information contained in these categories is presented in Table 10.1.

\subsubsection{Event Notification Procedure}

Staff members must make notifications to ensure activation of emergency response personnel and proper communication of facts to PNL management, DOE, and others.

NOTE: First priority is always given to the appropriate emergency action necessary to control an event.

PNL-MA-7 provides specific procedures in off-normal events requiring immediate emergency assistance, event notification procedures, off-normal event investigation, off-normal event reporting, and off-normal event recovery.

\subsection{Periodic Routine Effluent Monitoring Reports}

On a periodic basis, effluent monitoring data are gathered by PNL on specific DOE Richland Operations Office (RL) facilities for compilation and reporting to $\mathrm{DOE}$ and the various regulatory agencies.

The following report is submitted on a monthly basis.

- WDOE is provided with a status of all reportable spills from the previous month through RL.

The following reports are submitted on an annual basis.

- The Air Emissions Report for the Hanford Site is submitted to the EPA and the Washington Department of Health for the Hanford Site radiological emissions.

- The Annual Radioactive Effluent and Onsite Discharge Data Report is submitted to DOE-Headquarters, the EPA, and Washington Department of Health through RL after compilation by EG\&G Idaho.

- The Hanford Site Environmental Report is submitted to DOE-Headquarters, the EPA, WDOE, and the Washington Department of Health through RL. 
Table 10.1. Categorization of Off-Normal Events

\begin{tabular}{|c|c|c|c|c|}
\hline Condition/Event & Definition & $\mathbf{E}$ & UO & ONO \\
\hline \multicolumn{5}{|c|}{ Group 2) Environmental } \\
\hline \multirow[t]{9}{*}{$\begin{array}{l}\text { 2)A. } \\
\text { Radionuclide Releases }\end{array}$} & $\begin{array}{l}\text { Any release of radionuclide material to controlled or uncontrolled areas in } \\
\text { concentrations which, if averaged over a period of } 24 \text { hours, would exceed } \\
5 \text { times the respective Reportable Quantities (RQs) specified for such } \\
\text { materials in } 40 \text { CFR } 302 \text {. }\end{array}$ & $\mathrm{X}$ & & \\
\hline & $\begin{array}{l}\text { Release of a radionuclide material that exceeds a Federally permitted } \\
\text { release by the amount of a CERCLA RQ or, where no Federally permitted } \\
\text { release exists, the release exceeds the RQ. }\end{array}$ & & $\mathbf{X}$ & \\
\hline & $\begin{array}{l}\text { Release of radionuclide material that violates environmental requirements } \\
\text { in Federal permits, Federal regulations, or DOE standards. }\end{array}$ & & $\mathrm{X}$ & \\
\hline & $\begin{array}{l}\text { Release below Emergency levels which requires immediate (less than four } \\
\text { hours) reporting to Federal regulatory authorities or triggers specific action } \\
\text { levels for an outside Federal agency. }\end{array}$ & & $\mathbf{X}$ & \\
\hline & $\begin{array}{l}\text { Any release of radionuclide material to controlled or uncontrolled areas } \\
\text { that is not part of a normal monitored release and exceeds } 50 \% \text { of a } \\
\text { CERCLA RQ specified for such material per } 40 \text { CFR } 302 \text {. }\end{array}$ & & & $\mathrm{X}$ \\
\hline & $\begin{array}{l}\text { Any controlled release of radionuclide material that occurs as a monitored } \\
\text { part of normal operations which exceeds what historical data and/or } \\
\text { analysis show is expected as a result of normal operations. }\end{array}$ & & & $\mathbf{X}$ \\
\hline & $\begin{array}{l}\text { Any monitored facility or site boundary where exposure or concentrations } \\
\text { exceed what historical data and/or analysis show is expected as a result of } \\
\text { normal operations. }\end{array}$ & & & $\mathrm{X}$ \\
\hline & $\begin{array}{l}\text { Any detection of a radionuclide in a sanitary or storm sewer, waste or } \\
\text { process stream, or any holding points where such a material is not } \\
\text { expected. }\end{array}$ & & & $\mathrm{X}$ \\
\hline & $\begin{array}{l}\text { Any controlled, uncontrolled, or accidental release which is not classified } \\
\text { as an Unusual Occurrence but which will be reported in writing to State/ } \\
\text { local agencies in a format other than routine monthly or quarterly reports. }\end{array}$ & & & $\mathbf{x}$ \\
\hline \multirow{2}{*}{$\begin{array}{l}\text { 2)B. } \\
\text { Release of Hazardous } \\
\text { Substances/Regulated } \\
\text { Pollutants/Oil } \\
\text { (Spills or releases of } \\
\text { ethylene glycol and } \\
\text { glycol ethers reported } \\
\text { at levels in excess of } \\
100 \text { pounds) }\end{array}$} & $\begin{array}{l}\text { Any actual or potential release of material to the environment that results } \\
\text { in or could result in significant offsite consequences (e.g., need to relocate } \\
\text { people, major wildlife kills, major wetland degradation, major aquifer } \\
\text { contamination, need to secure downstream water supply intakes, etc.). }\end{array}$ & $\mathrm{X}$ & & \\
\hline & $\begin{array}{l}\text { Any release of hazardous substances or regulated pollutants in } \\
\text { concentrations which exceed } 5 \text { times the respective RQs specified for such } \\
\text { materials in } 40 \text { CFR } 302 \text {. }\end{array}$ & $\mathbf{X}$ & & \\
\hline
\end{tabular}


Table 10.1. (contd)

\begin{tabular}{|c|c|c|c|c|}
\hline Condition/Event & Definition & E & UO & ONO \\
\hline
\end{tabular}

Group 2) Environmental

2)B.

Release of Hazardous

Substances/Regulated

Pollutants/Oil

(Spills or releases of ethylene glycol and glycol ethers reported at levels in excess of 100 pounds)
Any actual or potential release of material to the environment that results in or could result in significant offsite consequences (e.g., need to relocate people, major wildlife kills, major wetland degradation, major aquifer contamination, need to secure downstream water supply intakes, etc.).

Any release of hazardous substances or regulated pollutants in concentrations which exceed 5 times the respective RQs specified for such materials in 40 CFR 302.

Release of a hazardous substance or regulated pollutant that exceeds a CERCLA RQ per $\mathbf{4 0}$ CFR 302 or exceeds a Federally permitted release by an RQ.

Release of a hazardous substance, regulated pollutant, or oil that violates environmental requirements in Federal permits, Federal regulations, or DOE standards.

Release below Emergency levels that requires immediate (less than four hours) reporting to Federal regulatory agencies or triggers specific action levels for an outside Federal agency.

Any release of 100 gallons or more of oil.

Release of a hazardous substance or regulated pollutant to controlled or uncontrolled areas that is not part of a normal, monitored release and exceeds $50 \%$ of a CERCLA RQ as specified for such material per 40 CFR 302.

Any release of oil less than Unusual Occurrence level but greater than 10 gallons.

Any detection of a toxic or hazardous substance in a sanitary or storm sewer, waste or process stream, or any holding points where such a material is not expected.

Any controlled, uncontrolled, or accidental release which is not classified as an Unusual Occurrence but which will be reported in writing to State/local agencies in a format other than routine monthly or quarterly reports.

Any controlled release of hazardous/regulated material that occurs as a monitored part of normal operations which exceeds what historical data and/or analysis shows is expected as a result of normal operations. 
Table 10.1. (contd)

\begin{tabular}{|c|c|c|c|c|}
\hline Condition/Event & Definition & $\mathrm{E}$ & UO & ONO \\
\hline \multicolumn{5}{|l|}{ Group 2) Environmental } \\
\hline & $\begin{array}{l}\text { Any general environmental monitoring where concentration increases } \\
\text { to a level which exceeds what historical data and/or analysis shows is } \\
\text { expected as a result of normal operations. }\end{array}$ & & & $\mathrm{X}$ \\
\hline \multirow{3}{*}{$\begin{array}{l}\text { 2)C. } \\
\text { Hazardous material } \\
\text { contamination due to } \\
\text { PNL operations }\end{array}$} & $\begin{array}{l}\text { Discovery of contamination that results or could result in significant } \\
\text { consequences (i.e., exceeding safe exposure limits to workers or } \\
\text { public). }\end{array}$ & $x$ & & \\
\hline & $\begin{array}{l}\text { Discovery of onsite or offsite hazardous material contaminations in } \\
\text { concentrations that exceed } 5 \text { times the respective RQs specified for } \\
\text { such materials in } 40 \text { CFR } 302 \text {. }\end{array}$ & $\mathrm{X}$ & & \\
\hline & $\begin{array}{l}\text { Discovery of onsite or offsite contamination due to PNL operations } \\
\text { which does not represent an immediate threat to the public, that } \\
\text { exceeds a reportable quantity for such materials per } 40 \text { CFR } 302 \text {. }\end{array}$ & & $\mathbf{x}$ & \\
\hline & $\begin{array}{l}\text { Any discovery of groundwater contamination that is not part of an } \\
\text { existing plume previously identified in either an annual report or in } \\
\text { any CERCLA/RCRA activity or report. }\end{array}$ & & $\mathrm{x}$ & \\
\hline & $\begin{array}{l}\text { Discovery of onsite contamination attributable to PNL operations that } \\
\text { exceeds } 50 \% \text { of a reportable quantity for such material per } \\
40 \text { CFR } 302 \text {. }\end{array}$ & & & $\mathbf{X}$ \\
\hline $\begin{array}{l}\text { 2)D. } \\
\text { Ecological Resources }\end{array}$ & $\begin{array}{l}\text { Any occurrence causing significant impact to any ecological resource } \\
\text { for which PNL is a trustee (i.e., destruction of a critical habitat, } \\
\text { damage to a historic/archeological site, damage to wetlands, etc.). }\end{array}$ & & $\mathbf{X}$ & \\
\hline \multirow[t]{3}{*}{$\begin{array}{l}\text { 2)E. } \\
\text { Agreement/Compliance } \\
\text { Activities }\end{array}$} & $\begin{array}{l}\text { Any agreement, compliance, remediation, or permit-mandated } \\
\text { activity for which formal notification has been received from the } \\
\text { relevant regulatory agency that a site plan is not satisfactory, or that } \\
\text { a site is considered to be in noncompliance with schedules or } \\
\text { requirements. }\end{array}$ & & $\mathbf{X}$ & \\
\hline & $\begin{array}{l}\text { Any occurrence under any agreement or compliance area that } \\
\text { requires notification of an outside regulatory agency within four } \\
\text { hours or less, or triggers an outside regulatory agency action level, } \\
\text { or otherwise indicates specific interest/concern from such agencies. }\end{array}$ & & $\mathrm{X}$ & \\
\hline & $\begin{array}{l}\text { Any occurrence under any agreement or compliance area that will be } \\
\text { reported in writing to outside agencies in a format other than routine } \\
\text { monthly or quarterly reports. }\end{array}$ & & & $\mathrm{X}$ \\
\hline
\end{tabular}




\subsection{Interface with the Operational Environmental Surveillance Program}

Environmental surveillance of the $\mathbf{3 0 0}$ area and the surrounding onsite and offsite areas is performed by the PNL Hanford Site Surface Environmental Surveillance Project and the PNL Site-Wide Groundwater Monitoring Project. These projects should be notified in the event of actual or apparent new or off-normal discharges to the soil, surface waters, or air so they can assist in assessing their environmental and compliance significance. The data from these programs are also useful to verify the occurrence or nonoccurrence of facility releases. These surveillance projects are described in detail in the Hanford Site Environmental Monitoring Plan. 


\subsection{Quality Assurance Plan}

A Quality Assurance Plan (Quality Assurance Plan for PNL Radionuclide Air Emission Monitoring, FO-011) was developed to address quality assurance with regard to radionuclide air emission monitoring. The QA Plan applies to Battelle's PNL facility airborne radionuclide emission monitoring activities.

The QA program described by the plan is based on the following documentation:

- the U.S. Environmental Protection Agency (EPA) QAMS-005/80, Interim Guidelines for Preparing Quality Assurance Project Plans

- DOE 5700.6C, "Quality Assurance"

- DOE 5400.1, "General Environmental Protection Program"

- DOE/EH-0173T, "Environmental Regulatory Guide for Radiological Effluent Monitoring and Environmental Surveillance"

- applicable criteria of ASME NQA-1, Quality Assurance Requirements for Nuclear Facilities, as reflected in PNL's Quality Assurance Manual, PNL-MA-70, and associated implementing procedures.

Additions to or deviations from PNL-MA-70 procedures are documented in the plan under the appropriate criteria headings.

The QA Plan addresses the sections of QAMS-005/80, with additional sections added to incorporate necessary modifications or clarifications to the supporting NAQ-1-and DOE Order 5700.6C-based QA Program, as documented in PNL-MA-70. A cross reference between the format used in the plan and the format recommended in DOE 5400.1 is provided in Appendix A to the plan. Where DOE Order 5400.1 requirements appear primarily in PNL-MA-70 instead of the plan, a reference to PNL-MA-70 is provided.

A QA Plan addressing monitoring of liquid effluents is being developed in concert with the installation and development of PNL's liquid effluent monitoring program. A plan has been drafted and will be finalized in 1995 . 


\subsection{Internal and External Plan Review}

DOE 5400.1 (DOE 1988a) states that the EMP will be reviewed annually and updated every three years. As a support document for the EMP, this FEMP will also be updated every three years. Additionally, this plan will be updated, as necessary, after each major change in facility processes, structure, ventilation and liquid collection systems, monitoring equipment, waste treatment, or a significant change to SARs or safety assessments. At a minimum, a FEMP assessment will be performed annually. 


\subsection{Compliance Assessment}

The sampling systems for radioactive air emissions have been upgraded to meet 40 CFR 61 requirements.

The point of environmental release of liquid effluents from the 327 Facility is the 300 Area process trench. Monitoring of 300 Area liquid effluents is conducted by WHC. PNL will initiate installation of liquid effluent sampling for the 327 Facility PS during FY 1995 as part of a program to characterize facility contributions to the 300 Area liquid waste streams.

\subsection{Basis for Compliance Assessment}

Standards and criteria used for system design and operation have been listed previously in Section 6.1. These include EPA requirements in 40 CFR 61, "National Emission Standard for Hazardous Air Pollutants" and DOE/EH-0173T, Environmental Regulatory Guide for Radiological Effluent Monitoring and Environmental Surveillance. These requirements are communicated to PNL management and staff via PNL-MA-8, Waste Management and Environmental Compliance.

\subsection{Summary of Existing Sampler Compliance Deficiencies and Scheduled Corrective Actions}

No compliance-related deficiencies have been identified for the existing 327 Facility stack sampling/monitoring system (Section 7.0).

\subsection{Program Upgrades}

Over the past several years, a significant effort has been made to upgrade PNL's effluent monitoring program. The upgrades are summarized as follows.

- The sampling system for radioactive air emissions have been upgraded to meet 40 CFR 61 requirements.

- Revisions to the liquid effluents chapters of PNL-MA-8 are being made. The revised chapters include administrative guidelines and practices for monitoring and controlling effluents to the liquid waste streams. Revisions are planned to be completed and issued by the end of 1994 .

- Procedures for collection and analysis of record air samplers have been periodically updated.

- The quality assurance plan, covering all elements of the PNL radioactive air emissions monitoring program, has been updated.

- Air sample line loss assessments have been performed using the DEPO computer code.

- Stack velocity and volumetric flow rate measurement procedures, conforming to EPA Method 2, have been implemented.

- Data accessibility, management, and security have been improved through database upgrades. 
- Documented statements of work have been prepared for required support functions such as sample collection, sample analysis, stack velocity measurement, instrument calibration, and maintenance.

- Data handling procedures have been documented.

Additional program upgrades are planned. These are as follows:

- The radioactive particulate CAM in the 327 Facility main stack will be upgraded.

- Documented statements of work will be prepared for database support.

- Liquid effluent sampling systems will be installed on facility process sewer lines and sampling started before 1995. 


\section{Lab Research and Management Summaries: 327 Facility}

\section{Canyon}

\section{Waste Compactor}

Description of Technical Activities: Compaction of low-level waste for the 327 Facility and limited amounts from other 300 Area activities.

Chemical/Radionuclide Inventory: Low-level radioactive materials are present here. The compaction of low-level waste is primarily in the form of gloves, wipes, and swabs.

Waste Streams and Their Management:

The compactor is a HEPA-filtered system to eliminate airborne contamination. Only qualified operators are allowed to perform the compacting and pre-paration of DOT-17 C or $\mathrm{H}$ barrels for disposal. This waste goes to the site disposal for retention.

\section{Decontamination Chamber}

Description of Technical Activities: This chamber is currently inactive. The chamber is primarily used for decontamination of structural material and/or equipment.

Chemical/Radionuclide Inventory: There is currently no radioactive material stored here.

Waste Streams and Their Management:

This chamber has an air filtering system and a drain for liquids. The chamber is vented to the process HEPA filtration system before being released to the atmosphere. The drain goes to RLWS sump located in the basement. Strict administrative controls are followed to maintain the safe operation of this chamber.

\section{Water Basins}

Description of Technical Activities: The basins consist of columns of mixed bed resins (nonhazardous) in ionized water, which is used to remove radionuclides. The water is maintained near the Derived Concentration Guides (DCGs). The basins are used for storing and loading/unloading shipping casks, store encapsulated fuels and other irradiated structural materials.

Chemical/Radionuclide Inventory: The basins store radionuclides, fuels, and irradiated materials. The basins are dynamic storage areas and the inventory changes.

Waste Streams and Their Management:

All liquids from the basins drain, by way of the overflow or the drain, to the RLWS line for retention and are released to the RLWS treatment facility (340 Facility) for sampling and disposal. 


\section{Dry Storage}

Description of Technical Activities: Storage of fuels and irradiated materials.

Chemical/Radionuclide Inventory: Radionuclides, fuels, and irradiated materials. This is a dynamic storage area and the inventory changes.

Waste Streams and Their Management:

The dry storage unit is ducted to the HEPA system and through the activated charcoal filter bank before effluents are released to the atmosphere via the monitored stack. The inventory is monitored and controlled by the facility material balance custodian who is responsible for accounting for material under safeguards and security control.

\section{A-Cell}

Description of Technical Activities: This cell is used primarily for general utility and observation. Transuranic (TRU) waste compaction/waste packaging is performed within this cell.

Chemical/Radionuclide Inventory: TRU waste is compacted here for disposal.

Waste Streams and Their Management:

The cell is ducted to the HEPA system and through the activated charcoal filter bank before effluents are released to the atmosphere. Liquids drain into the RLWS system. The inventory is monitored and controlled by the facility material balance custodian. Any chemicals introduced to the cell are under strict administrative controls. The hazardous material custodian maintains the chemical inventory.

\section{B-Cell}

Description of Technical Activities: Irradiated material sample preparation (nonfuel) and storage.

Chemical/Radionuclide Inventory: Non-TRU waste is found in this cell.

Waste Streams and Their Management:

The cell is ducted to the HEPA system and through the activated charcoal filter bank before effluents are released to the atmosphere. Liquids drain into the RLWS system. The inventory is monitored and controlled by the facility material balance custodian. Any chemicals introduced to the cell are under strict administrative controls. The hazardous material custodian maintains the chemical inventory.

\section{C-Cell}

Description of Technical Activities: Metallography material sample preparation of irradiated fuels and structural materials.

Chemical/Radionuclide Inventory: TRU waste is found in this cell. 
Waste Streams and Their Management:

The cell is ducted to the HEPA system and through the activated charcoal filter bank before effluents are released to the atmosphere. Liquids drain into the RLWS system. The inventory is monitored and controlled by the facility material balance custodian. Any chemicals introduced to the cell are under strict administrative controls. The hazardous material custodian maintains the chemical inventory.

\section{D-Cell}

Description of Technical Activities: Work performed within this cell includes fuel transient testing and specimen profilometry.

Chemical/Radionuclide Inventory: TRU waste is found in this cell.

Waste Streams and Their Management:

The cell is ducted to the HEPA system and through the activated charcoal filter bank before effluents are released to the atmosphere. Liquids drain into the RLWS system. The inventory is monitored and controlled by the facility material balance custodian. Any chemicals introduced to the cell are under strict administrative controls. The hazardous material custodian maintains the chemical inventory.

\section{E-Cell}

Description of Technical Activities: Metallography material sample preparation of irradiated materials and fuels.

Chemical/Radionuclide Inventory: TRU waste is found in this cell.

Waste Streams and Their Management:

The cell is ducted to the HEPA system and through the activated charcoal filter bank before effluents are released to the atmosphere. Liquids drain into the RLWS system. The inventory is monitored and controlled by the facility material balance custodian. Any chemicals introduced to the cell are under strict administrative controls. The hazardous material custodian maintains the chemical inventory.

\section{F-Cell}

Description of Technical Activities: This cell is primarily used for general utility, fabrication, machining, and sample preparation on fuels and/or structural materials.

Chemical/Radionuclide Inventory: TRU waste is found in this cell.

Waste Streams and Their Management:

The cell is ducted to the HEPA system and through the activated charcoal filter bank before effluents are released to the atmosphere. Liquids. drain into the RLWS system. The inventory is monitored and controlled by the facility material 
balance custodian. Any chemicals introduced to the cell are under strict administrative controls. The hazardous material custodian maintains the chemical inventory.

\section{G-Cell}

Description of Technical Activities: Work performed in this cell includes fabrication, machining sample preparation, profilometry of structural irradiated materials, and dissolution of medical sources.

Chemical/Radionuclide Inventory: Non-TRU waste is found in this cell.

Waste Streams and Their Management:

The cell is ducted to the HEPA system and through the activated charcoal filter bank before effluents are released to the atmosphere. Liquids drain into the RLWS system. The inventory is monitored and controlled by the facility material balance custodian. Any chemicals introduced to the cell are under strict administrative controls. The hazardous material custodian maintains the chemical inventory.

\section{H-Cell}

Description of Technical Activities: This cell is used primarily for specialized testing to suit the customers needs.

Chemical/Radionuclide Inventory: Non-TRU waste is found in this cell.

Waste Streams and Their Management:

The cell is ducted to the HEPA system and through the activated charcoal filter bank before effluents are released to the atmosphere. Liquids drain into the RLWS system. The inventory is monitored and controlled by the facility material balance custodian. Any chemicals introduced to the cell are under strict administrative controls. The hazardous material custodian maintains the chemical inventory.

\section{I-Cell}

Description of Technical Activities: Work performed in this cell includes corrosion testing/weighing of commercial spent fuel. An evaporator cell (carbon coating) is attached to this cell.

Chemical/Radionuclide Inventory: Non-TRU waste is found in this cell.

Waste Streams and Their Management:

The cell is ducted to the HEPA system and through the activated charcoal filter bank before effluents are released to the atmosphere. Liquids drain into the RLWS system. The inventory is monitored and controlled by the facility material balance custodian. Any chemicals introduced to the cell are under strict administrative controls. The hazardous material custodian maintains the chemical inventory. 
SERF Cell

Description of Technical Activities: This cell is used primarily for metallography. Irradiated fuels are prepared for sectioning, gas sampling, photography, and microhardness. This cell is maintained as a nitrogen-charged atmosphere. A storage cell is located in the basement.

Chemical/Radionuclide Inventory: TRU waste is found in this cell.

Waste Streams and Their Management:

The cell and storage is ducted to the HEPA system and through the activated charcoal, filter bank before effluents are released to the atmosphere. Liquids drain into the RLWS system. The inventory is monitored and controlled by the facility material balance custodian. Any chemicals introduced to the cell are under strict administrative controls. The hazardous material custodian maintains the chemical inventory.

\section{Elevator Room}

Description of Technical Activities:

This room contains a fume hood used primarily for decontamination.

Chemical/Radionuclide Inventory: Low levels of TRU waste can be generated in this hood. A small volume of chromium trioxide, sodium hydroxide, and mercury (thermometer) is located within this room in a chemical storage cabinet, with the exception of the thermometer, which is located in a locked cabinet.

Waste Streams and Their Management:

The hood and room are ducted to the HEPA system and emitted through the monitored stack to the atmosphere. Liquids drain into the RLWS system. The radioisotope and chemical inventory are monitored and controlled by the facility material balance custodian and hazardous material custodian, respectively, via the approved requirements for disposal. Any chemicals introduced to the room are under strict administrative controls.

\section{Low-Level Lab}

Description of Technical Activities: This room contains a fume hood used primarily for decontamination.

Chemical/Radionuclide Inventory: Low levels of TRU waste can be generated in this hood.

Waste Streams and Their Management:

The hood and room are ducted to the HEPA system and emitted through the monitored stack to the atmosphere. Liquids drain into the RLWS system. The radioisotope and chemical inventory are monitored and controlled by the facility material balance custodian and hazardous material custodian, respectively, via the approved requirements for disposal. Any chemicals introduced to the lab are under strict administrative controls. 


\section{Dark Room (Planned to Be Removed in 1994)}

Description of Technical Activities: This room is used primarily for developing film for various contractors.

Chemical/Radionuclide Inventory: Fixer and developer for film processing.

Waste Streams and Their Management:

The fixer is tested and then transferred to the hazardous material custodian. The developer goes to the RLWS sump for sampling and disposal. Process water goes to the RPS drain. Any chemicals introduced to the dark room are under strict administrative controls. The hazardous material custodian maintains the chemical inventory.

Floor Drains and Machine Shop

Description of Technical Activities: These areas contain floor drains. The machine shop sink drains to the RPS.

Chemical/Radionuclide Inventory: Not applicable.

Waste Streams and Their Management:

These drains feed into the RLWS system. 


\section{Appendix B}

\section{Projection of Offsite Emission Dose}

DOE Order 5400.1 states that Environmental Monitoring Plans (EMP) "shall be prepared for each site, facility, or process that uses, generates, releases, or manages significant pollutants or hazardous materials" (DOE Order 5400.1, IV-2). To support the EMP, FEMPs are being prepared for those facilities that have the potential to release significant pollutants or hazardous materials. A methodology has been developed to determine whether potential releases of radioactive material are significant. This method is the same as that used to determine whether monitoring is required for the National Emission Standards for Hazardous Air Pollutants (NESHAPs - U.S. Code of Federal Regulations, Title 40 Part 161, Subparts H and I) and is described in Pacific Northwest Laboratory Facilities Radionuclide Inventory Assessment CY 1992-1993 (Sula and Jette 1994, PNL-10061).

The first step in the method (called the FEMP Determination when used to determine whether or not a FEMP is needed for a facility) is to obtain a listing of the facility inventory. The inventory includes the radionuclide, isotope, quantity, and form. Form can be gas, liquid or powder, solid (nondispersible), contained (in sealed sourced or DOT containers), or exempt (sealed sources meeting certain criteria). At PNL, radioactive source and material information is maintained using three separate inventory systems: (1) facilities management radioactive materials inventory, (2) composite radioactive materials inventory, and (3) nuclear materials inventory. An identifier on the inventory listing indicates the inventory system that the information was obtained from. Additional detail on the FEMP Determination method is provided in PNL-10061. The attached table contains the inventory information for the 327 Facility for 1994 . The total unmitigated dose from the inventory is 150 mrem using the inventory-based method. Most of this dose is from

$\mathrm{PuO}_{2}$ powder. 
Table B.1. 1993 PNL Facility Radionuclide Inventory Assessment

\begin{tabular}{|c|c|c|c|c|c|c|c|c|}
\hline$\frac{\text { Nuclide }}{\text { U(dep) }}$ & $\frac{\text { Quantity }}{6.24 E+03}$ & $\frac{\text { Units }}{\text { grams }}$ & $\frac{\text { Form }}{s}$ & $\frac{\text { Inv. }}{3}$ & $\frac{\text { Rel.Proi. }}{6.2 \text { E-03 }}$ & $\frac{\text { Units }}{\text { grams }}$ & $\frac{\text { Dose Fact. }}{2.33 E-05}$ & $\frac{\text { Dose }}{1.5 \mathrm{E}-07}$ \\
\hline$U$ (nat) & $4.32 E+02$ & grams & s & 3 & 4.3E-04 & grams & 4.4OE-05 & $1.9 \mathrm{E}-08$ \\
\hline$U(20 \%)$ & $1.11 E+04$ & grams & s & 3 & $1.1 E-02$ & grams & $6.41 E-04$ & 7.1E-06 \\
\hline$U(90 \%)$ & $4.65 E+03$ & grams & s & 3 & 4.7E-03 & grams & $4.25 E-03$ & 2.0E-05 \\
\hline Th-232 & $2.18 E+02$ & grams & s & 3 & $2.2 E-04$ & grams & $2.18 E-05$ & 4.7E-09 \\
\hline Am-241 & $5.10 \mathrm{E}-01$ & grams & s & 3 & $5.1 \mathrm{E}-07$ & grams & $9.50 E+02$ & $4.8 E-04$ \\
\hline $\mathrm{Cm}-244$ & $4.50 \mathrm{E}-01$ & grams & $s$ & 3 & $4.5 E-07$ & grams & $1.29 E+04$ & $5.8 \mathrm{E}-03$ \\
\hline Np-237 & $3.99 E+00$ & grams & s & 3 & 4.0E-06 & grams & $1.84 E-01$ & $7.4 \mathrm{E}-07$ \\
\hline $\mathrm{Pu}(12 \%)$ & $2.52 E+03$ & grams & s & 3 & $2.5 \mathrm{E}-03$ & grams & $1.92 E+01$ & $4.8 E-02$ \\
\hline FE-55 & $4.89 E+03$ & $c t$ & s & 1 & 4.9E-03 & $C i$ & $7.02 E-03$ & $3.4 \mathrm{E}-05$ \\
\hline $\mathrm{MN}-54$ & $3.46 \mathrm{E}+02$ & $\mathrm{Cl}$ & $\mathbf{s}$ & 1 & $3.5 E-04$ & $c t$ & $3.50 E-01$ & 1.2E-04 \\
\hline Co-60 & $1.69 E+02$ & $c i$ & s & 1 & 1.7E-04 & $c t$ & $5.11 E+00$ & 8.6E-04 \\
\hline NI-63 & $7.10 E+01$ & $c i$ & s & 1 & 7.1E-05 & $c$ & $1.05 E-02$ & 7.5E-07 \\
\hline EU-155 & $1.04 E+03$ & $c i$ & $\mathbf{s}$ & 1 & $1.0 \mathrm{E}-03$ & $c t$ & $1.71 E-01$ & $1.8 \mathrm{E}-04$ \\
\hline$S M-151$ & $1.49 E+03$ & $\mathrm{Cl}$ & $\mathbf{s}$ & 1 & $1.5 E-03$ & $c t$ & $1.80 E-02$ & 2.7E-05 \\
\hline PM-147 & $3.29 E+04$ & $\mathrm{Cl}$ & s & 1 & 3.3E-02 & $C r$ & $2.84 E-02$ & 9.3E-04 \\
\hline PR-144 & $3.90 E+03$ & $C l$ & s & 1 & $3.9 \mathrm{E}-03$ & $\mathrm{Cr}$ & $3.17 E-05$ & $1.2 \mathrm{E}-07$ \\
\hline CE-144 & $3.90 \mathrm{E}+03$ & $\mathrm{Ci}$ & s & 1 & $3.9 \mathrm{E}-03$ & $\mathrm{Cr}$ & $3.81 E-01$ & 1.5E-03 \\
\hline CS-137 & $2.73 E+04$ & $C i$ & s & 1 & 2.7E-02 & $C t$ & $5.02 E+00$ & $1.4 \mathrm{E}-01$ \\
\hline TE-125M & $1.25 E+02$ & $C i$ & s & 1 & $1.3 E-04$ & $C t$ & $3.56 E-02$ & 4.5E-06 \\
\hline SB-1 25 & $5.72 E+02$ & $c t$ & s & 1 & 5.7E-04 & $c t$ & $6.32 E-01$ & 3.6E-04 \\
\hline$R U-106$ & $5.04 E+03$ & $C r$ & $\mathbf{s}$ & 1 & $5.0 \mathrm{E}-03$ & $\mathrm{Cl}$ & $4.83 E-01$ & $2.4 \mathrm{E}-03$ \\
\hline$Y-90$ & $1.31 E+04$ & $c t$ & $\mathbf{s}$ & 1 & $1.3 E-02$ & $C i$ & $1.12 E-02$ & $1.5 \mathrm{E}-04$ \\
\hline SR-90 & $1.31 E+04$ & $C i$ & $s$ & 1 & $1.3 E-02$ & $c$ & $4.96 E+00$ & $6.5 E-02$ \\
\hline KR-85 & $1.41 E+03$ & $c i$ & $s$ & 1 & $1.4 \mathrm{E}-03$ & $c t$ & $9.42 E-07$ & $1.3 E-09$ \\
\hline $\mathrm{H}-3$ & $6.20 E+01$ & $C i$ & s & 1 & $6.2 E-05$ & $\mathrm{Ct}$ & $4.23 E-04$ & 2.6E-08 \\
\hline CS-137 & $9.31 E+05$ & $a$ & s & 1 & $9.3 \mathrm{E}-01$ & $\mathrm{Cl}$ & $5.02 E+00$ & 4.7E + OO \\
\hline TH-230 & 3.00E-09 & $\mathrm{Cl}$ & c & 2 & $0.0 E+00$ & $C r$ & $1.21 E+02$ & $0.0 E+00$ \\
\hline SR-90 & $1.42 \mathrm{E}-03$ & $c t$ & c & 2 & $0.0 E+00$ & $a$ & $4.96 E+00$ & $0.0 E+00$ \\
\hline SR-90 & $1.42 \mathrm{E}-03$ & $C i$ & c & 2 & $0.0 E+00$ & $c i$ & $4.96 E+00$ & $0.0 E+00$ \\
\hline $\mathrm{CO}-60$ & $7.00 \mathrm{E}-03$ & $c i$ & $c$ & 2 & $0.0 E+00$ & $a$ & $5.11 E+00$ & $0.0 E+00$ \\
\hline $\mathrm{CO}-60$ & $5.60 \mathrm{E}-04$ & $\mathrm{Cl}$ & c & 2 & $0.0 E+00$ & $c i$ & $5.11 E+00$ & $0.0 E+00$ \\
\hline Co-60 & 4.51E-05 & $C r$ & $c$ & 2 & $0.0 E+00$ & $c i$ & $5.11 E+00$ & $0.0 E+00$ \\
\hline$U-233$ & $2.28 \mathrm{E}+01$ & grams & $L$ & 3 & 2.3E-02 & grams & 7.09E-01 & 1.6E-02 \\
\hline
\end{tabular}


Table B.1. (contd)

$\begin{array}{crlllllll}\text { Pu-238 } & 1.32 E+01 & \text { grams } & \mathrm{C} & 3 & 0.0 \mathrm{E}+00 & \text { grams } & 3.16 E+03 & 0.0 \mathrm{E}+00 \\ \mathrm{Pu}-238 & 6.85 \mathrm{E}+00 & \text { grams } & \mathrm{L} & 3 & 6.9 \mathrm{E}-03 & \text { grams } & 3.16 E+03 & 2.2 \mathrm{E}+01 \\ \mathrm{PU}-238 & 1.25 \mathrm{E}+01 & \text { grams } & \mathrm{S} & 3 & 1.2 \mathrm{E}-05 & \text { grams } & 3.16 E+03 & 3.9 \mathrm{E}-02 \\ \mathrm{PU}-238 & 7.30 \mathrm{E}-01 & \text { grams } & \mathrm{S} & 3 & 7.3 \mathrm{E}-07 & \text { grams } & 3.16 E+03 & 2.3 \mathrm{E}-03 \\ \mathrm{PU}-238 & 3.80 \mathrm{E}+01 & \text { grams } & \mathrm{L} & 3 & 3.8 \mathrm{E}-02 & \text { grams } & 3.16 E+03 & 1.2 \mathrm{E}+02 \\ \mathrm{H}-3 & 4.00 \mathrm{O}-02 & \text { grams } & \mathrm{S} & 3 & 4.0 \mathrm{E}-08 & \text { grams } & 4.19 E+00 & 1.7 \mathrm{E}-07\end{array}$




\section{Appendix C}

\section{Nonradioactive Hazardous Materials Characterization}

DOE Order 5400.1 states that Environmental Monitoring Plans (EMP) "shall be prepared for each site, facility, or process that uses, generates, release s, or manages significant pollutants or hazardous materials" (DOE Order 5400.1, IV-2). The FEMPs that are being prepared to support the EMP include the consideration of nonradioactive hazardous materials. No methodology has been developed to determine the potential release of nonradioactive hazardous chemicals, but hazardous chemicals are considered for the facilities that are determined to need a FEMP from potential radioactive airborne emissions.

A listing of the chemicals used in the facility is obtained using the PNL Chemical Inventory System. The inventory information includes the location, chemical name, and quantity. In some cases the manufacturer and individual container quantities are also tracked. In addition, the CIS data includes the RQ of the chemical. RQs are obtained from 40 CFR 302 and are the amounts which, if released to the environment from a facility, require notification to the National Response Center. RQs can indicate the relative hazard of a chemical. For the FEMP facilities, chemicals that may be present in greater than RQ amounts were identified to characterize the potential for emissions of nonradioactive hazardous materials. Hydrogen peroxide with an RQ of $453.59 \mathrm{~g}$ was listed in quantities of $566.99 \mathrm{~g}$ in the 327 Facility and was the only chemical in the 327 Facility in greater than RQ amounts. 


\title{
Appendix D
}

\author{
Data from Waste Stream Characterization Report \\ (Westinghouse Hanford Company. 1992. Hanford 300 Area \\ Process Wastewater Characterization Data Report. \\ WHC-SD-L045H-DP-001, Rev. 0, Westinghouse Hanford \\ Company, Richland Washington)
}

\section{Summary of Data from Waste Stream Characterization Report}

\begin{tabular}{|c|c|c|c|c|c|}
\hline \multirow[b]{2}{*}{ Analyte } & \multicolumn{3}{|c|}{ Date Samples Taken } & \multirow[b]{2}{*}{$\mathrm{ACV}$} & \multirow[b]{2}{*}{$\%$ of $\mathrm{ACV}$} \\
\hline & $5 / 25 / 89$ & $5 / 31 / 89$ & $6 / 8 / 89$ & & \\
\hline Beta, $\mathrm{pCi} / \mathrm{L}$ & 5.53 & 14.7 & 13.1 & 120 & 12 \\
\hline $\mathrm{Ra}$ total, $\mathrm{pCi} / \mathrm{L}$ & & 0.174 & & & \\
\hline Acetone, ppb & 30 & 31 & & & \\
\hline Alkalinity, ppb & 47,100 & 44,300 & 36,200 & & \\
\hline Aluminum, ppb & & & 220 & & \\
\hline Barium, ppb & 27 & 31 & 28 & 1,000 & 3 \\
\hline Bis(ethylhexyl)pthlate & 15 & & & & \\
\hline Boron, pp & & & 19 & & \\
\hline Calcium, ppb & 16,200 & 17,800 & 14,800 & & \\
\hline Chloride, ppb & 3,400 & 3,300 & 3,900 & 250,000 & 2 \\
\hline Chloroform, $\mathrm{ppb}$ & 47 & 51 & 66 & & \\
\hline Conductivity & 133 & 133 & 133 & & \\
\hline Copper, ppb & 12 & & 18 & 1,000 & 2 \\
\hline Dichlorodifluoromethane & 58 & & 183 & & \\
\hline Fluoride, ppb & 182 & 209 & 190 & 2,000 & 10 \\
\hline Iron, $\mathrm{ppb}$ & 212 & 80 & 179 & & \\
\hline Lead, ppb & 5 & & 5 & 50 & 10 \\
\hline Magnesium, ppb & 3,980 & 4,260 & 3,660 & & \\
\hline Manganese, $\mathrm{ppb}$ & 6 & & 6 & & \\
\hline Nickel & & & 11 & & \\
\hline Nitrate, $\mathrm{ppb}$ & 700 & 950 & & 45,000 & 2 \\
\hline $\mathrm{pH}$ & 6 & 6 & 5.63 & $2-12.5$ & \\
\hline Potassium, ppb & 830 & 816 & 757 & & \\
\hline 2-Propanol & 115 & 71 & & & \\
\hline Silicon, ppb & 2,870 & 2,760 & 2,720 & & \\
\hline Sodium, ppb & 3,590 & 2,610 & 2,340 & & \\
\hline Strontium, $\mathrm{ppb}$ & 77 & 82 & 72 & & \\
\hline Sulfate, $\mathrm{ppb}$ & 16,900 & 17,200 & 17,300 & 250,000 & 7 \\
\hline Temperature & 20.8 & 20.8 & 24 & & \\
\hline Total Organic Carbon & 5,500 & 3,900 & & & \\
\hline Total Carbon, ppb & 16,200 & 14,600 & 11,200 & & \\
\hline Total dis. solids & 83,000 & 65,000 & 59,000 & & \\
\hline TOX & 306 & 268 & 390 & & \\
\hline Unknown PAH & & 35 & & & \\
\hline Uranium, ppb & 0.406 & & 0.268 & & \\
\hline Zinc, ppb & 97 & 80 & 80 & & \\
\hline
\end{tabular}


Sample Point Number: 9

Location: Basement of 327 , (see drawing H-3-57573, sheet 2)

Type: Drip Sampler

Buildings involved: 327 (partial, Radiation Protection Sewer)

Notes: Contact Del Deschane, check upstream sightglass for flow.

Diagram:
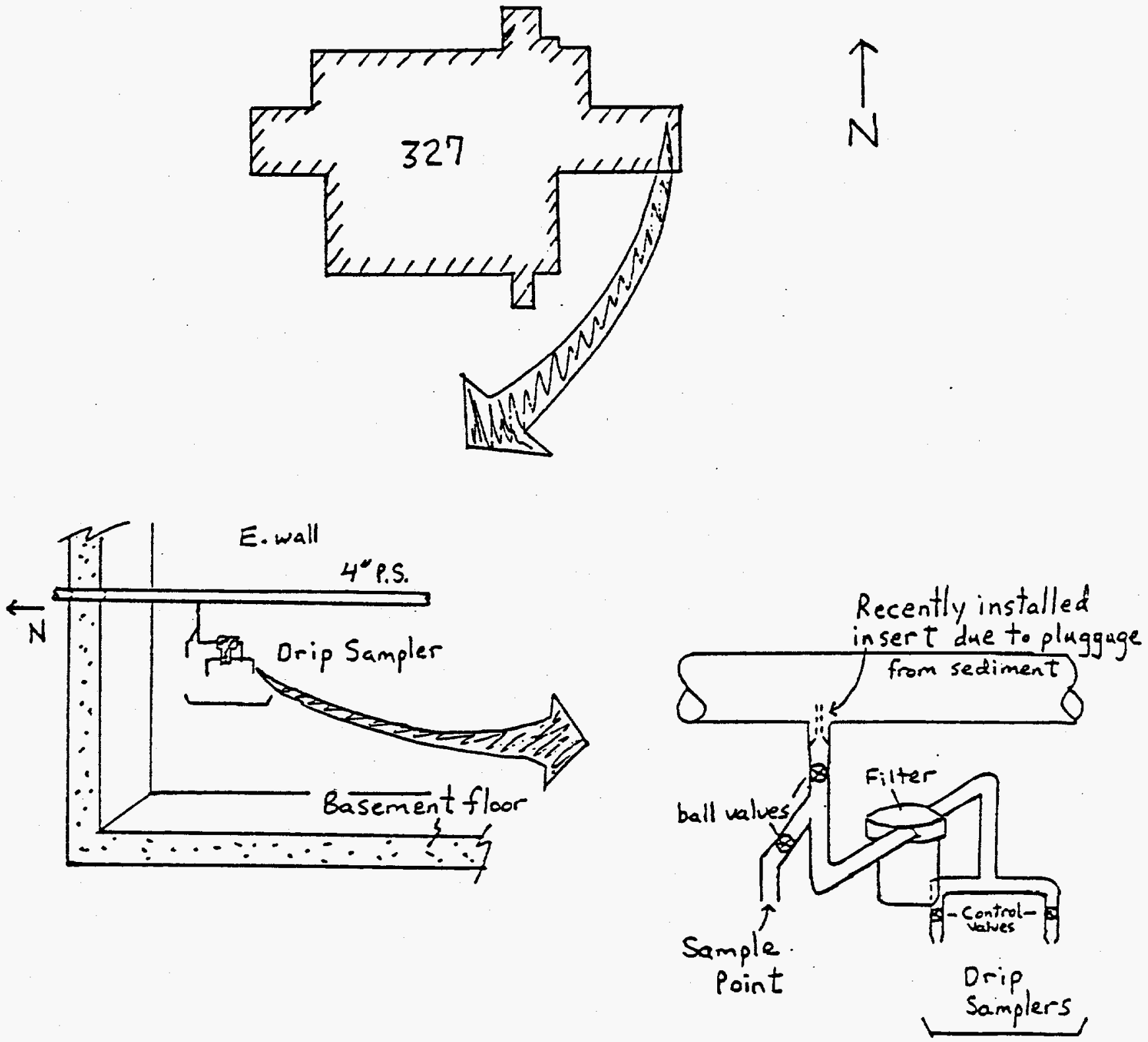
Sample 58124: 05/25/89 09:14, 3w08

$(B=58125, T=58126)$

Kearingful Results

\begin{tabular}{|c|c|c|}
\hline \multirow[b]{2}{*}{ Rey } & \multicolumn{2}{|c|}{ 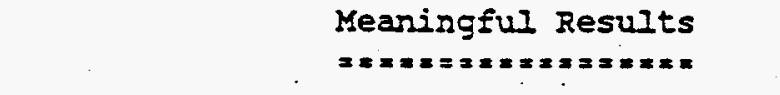 } \\
\hline & Analyte & Result \\
\hline & Beta Activity (pCi/I) & $5.53 E+\infty 0$ \\
\hline & Acetone (VOA) & $3.00 \Sigma+01$ \\
\hline s & Altalisity (Method B) & $4.712+04$ \\
\hline s & Barium & $2.70 E+O I$ \\
\hline s & Bis(ethylhexyl) phthalate & $1.50 E+01$ \\
\hline $\mathbf{s c}$ & Calciun & $1.62 \mathrm{E}+04$ \\
\hline s c & coloride & $3.405+03$ \\
\hline $\mathbf{s}$ & Ciloroform & $4.70 E+01$ \\
\hline sc & Conductivity-Field (us) & $1.33 E+02$ \\
\hline$s$ & Copper & $1.20 E+01$ \\
\hline s I & Dichlorodifluoromethare & $5.80 E+01$ \\
\hline s & Fluoride (ISE) & $1.82 \Sigma+02$ \\
\hline$s:$ & Iron & $2.12 \Sigma+02$ \\
\hline S I & Iead (GFAA) & $5.00 \Sigma+00$ \\
\hline s: & Magnesium & $3.98 E+03$ \\
\hline S s & Manganese & $6.00 \Sigma \div 00$ \\
\hline S 1 & Nitrate & $7.00 E+02$ \\
\hline $5 \xi$ & pH-Field & $6.00 \Sigma+00$ \\
\hline$S E$ & Fotassium & $8.30 z+02$ \\
\hline 52 & 2-2ropanol & $1.15 \Xi+02$ \\
\hline$s \mathbf{s}$ & silicon & $2.87 \Sigma+03$ \\
\hline s $s$ & Sodiun & $3.59 E+03$ \\
\hline s s & Strontius & $7.70 E+0.1$ \\
\hline s $s$ & sulfate & $1.69 \Sigma+04$ \\
\hline$S \mathbf{I}$ & Temperature-Field (celsius) & $2.08 E+01$ \\
\hline$S I$ & TOC & $5.50 E+03$ \\
\hline$S T$ & Total Carbon & $1.625+04$ \\
\hline$S I$ & Total Dissolved Solids & $8.30 \Sigma+04$ \\
\hline$S I$ & $\operatorname{TOX}(I D L)$ & $3.06 \mathrm{E}+02$ \\
\hline su & Uranium & $4.06 E-01$ \\
\hline s. & Uranium & $2.15 E-01$ \\
\hline$s z$ & zinc & $9.70 E+01$ \\
\hline
\end{tabular}


Meaningful Results

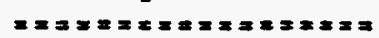

Key

Aralyte

Result

S Beta Activity (PCi/L)

1. $47 E+01$

$S$ Ra Total ( $P C i / L)$

1.74E-0I

$S$ Acetone (VOA)

$3.10 E+01$

S Alkalinity (Method B)

4. $43 E+04$

$S$ Barium

$3.10 E+01$

s calciun

$s$ choride

1. $78 \mathrm{E}+04$

$s$ chlorofora

3. $305 \div 03$

$s$ Conductivity-Field (us)

5. $10 . E \div 01$

$S$ Fluoride (ISE)

1. $33 E+02$

$2.09 E+02$

$s$ Iron

8. $00 E+01$

S Magnesium

4. $26 \mathrm{E}+03$

s Nitrate

s pR-Field

$9.50 \mathrm{E}+02$

$s$ Potassiun

$6.00 \mathrm{E}+00$

8. $16 E+02$

5 2-Propanol

$7.10 E+01$

5 silicon

2. $76 \mathrm{E}+03$

S sodiun

S strontium

$2.61 \equiv+03$

S Sulfate

8. $20 \mathrm{E}+01$

1. $72 \Xi+04$

S Temperature-Field (celsius)

$s$ Toc

2. $08 \mathrm{E}+01$

$S$ Total Carbon

3. $90 \mathrm{E}+03$

S Total Dissolved Solids

1. $46 E+04$

$S \operatorname{mox}(I D I)$

6. $50 \mathrm{E}+04$

$2.68 \mathrm{E}+02$
$S$ UnMOWR PAI
3. $50 E+01$
5 zinc
$8.00 E+01$

Key: $S$ = Sample, $E$ = Extract, $B=$ Blank, $T=T=i p$ Blank 
Sample 58175: 06/08/89 13:37, 3w08

$(B=58176, T=58177)$

Meaningful Results

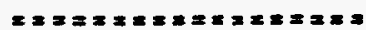

Key

Analgte

Result

S Beta Activity (pCi/I)

$1.31 E+01$

$S$ Alralioity (Method B)

$3.62 \mathrm{E}+04$

5 Aluminum

$2.20 E+02$

5 Barium

$2.80 E+01$

$S$ Boron

$1.90 \mathrm{E}+01$

$s$ Calciura

1. $48 E+04$

$s$ alorice

3. $90 \mathrm{E}+03$

$S$ Chloroform

$6.60 E+01$

s Conductivity-Field (us)

1. $33 E+02$

$s$ Copper

1. $80 \mathrm{E}+01$

S Dichlorodifluoromethane

$1.83 E+02$

$S$ Fluoride (ISE)

$1.90 \mathrm{E}+02$

$s$ Iron

$S$ Iead (GFAA)

1. $79 \pm+02$

s Magnesium

$5.00 \Sigma+00$

$3.66 \Sigma+03$

5 Manganese

5 Nickel

S PE-Fiezd

$6.00 E+00$

s Potassium

1. $10 E+01$

$5.63 E+00$

$7.57 E+02$

5 silicon

$2.72 \mathrm{E}+03$

S Sodiun

2. $34 E+03$

s strontium

$7.20 \Xi+01$

s sulfate

1. $73 E+04$

s Temperature-Field (celsius)

2. $40 E+01$

$s$ Total carbon

$1.12 \mathrm{E}+04$

$s$ Total Dissolved Solids

5. $90 E+04$

$S \operatorname{TOX}$ (IDL)

3. $90 \mathrm{E}+02$

5 Uranium

2. $68 \Sigma-01$

s zinc

$8.00 E+01$

Key: $S=$ Sample, $E$ = Extract, $B=$ Blank, $I=$ Trip Blank 
Summary of Data from Waste Stream Characterization Report

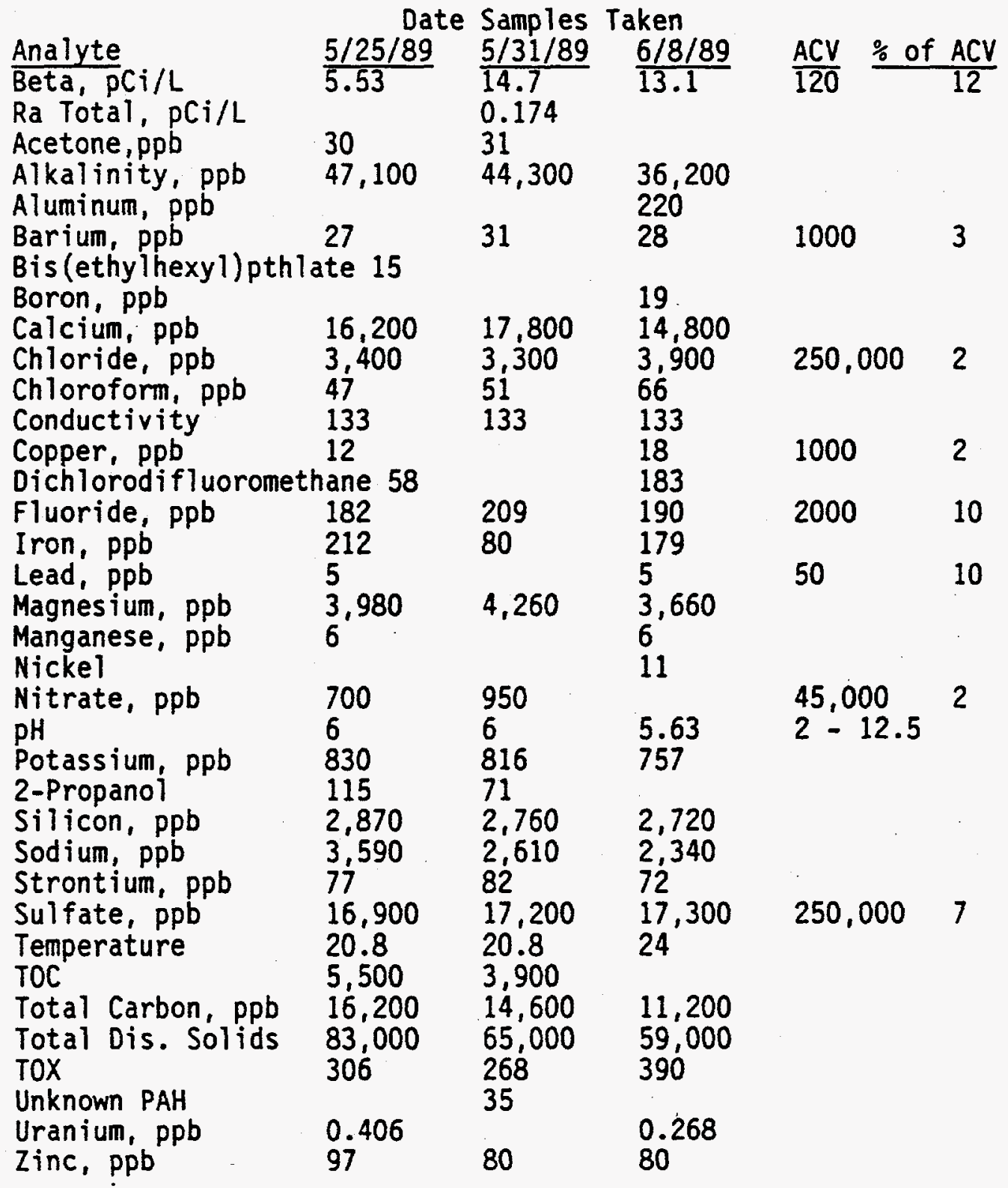




\section{Appendix E}

Ventilation and Sewer System Flow Pathways 